
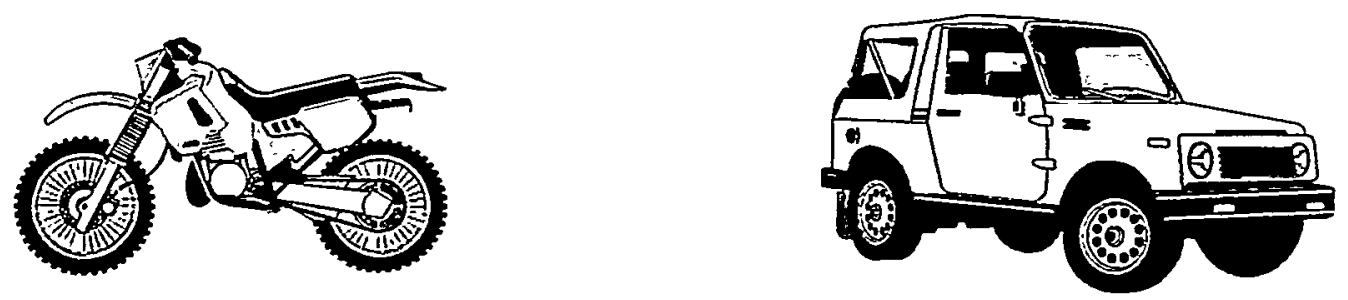

Fuel Used for Off-Road Recreation:

A Reassessment of the Fuel Use Model

\author{
Stacy C. Davis \\ Lorena F. Truett \\ Patricia S. Hu
}
RECEIVED
AUG 181999
OSTI
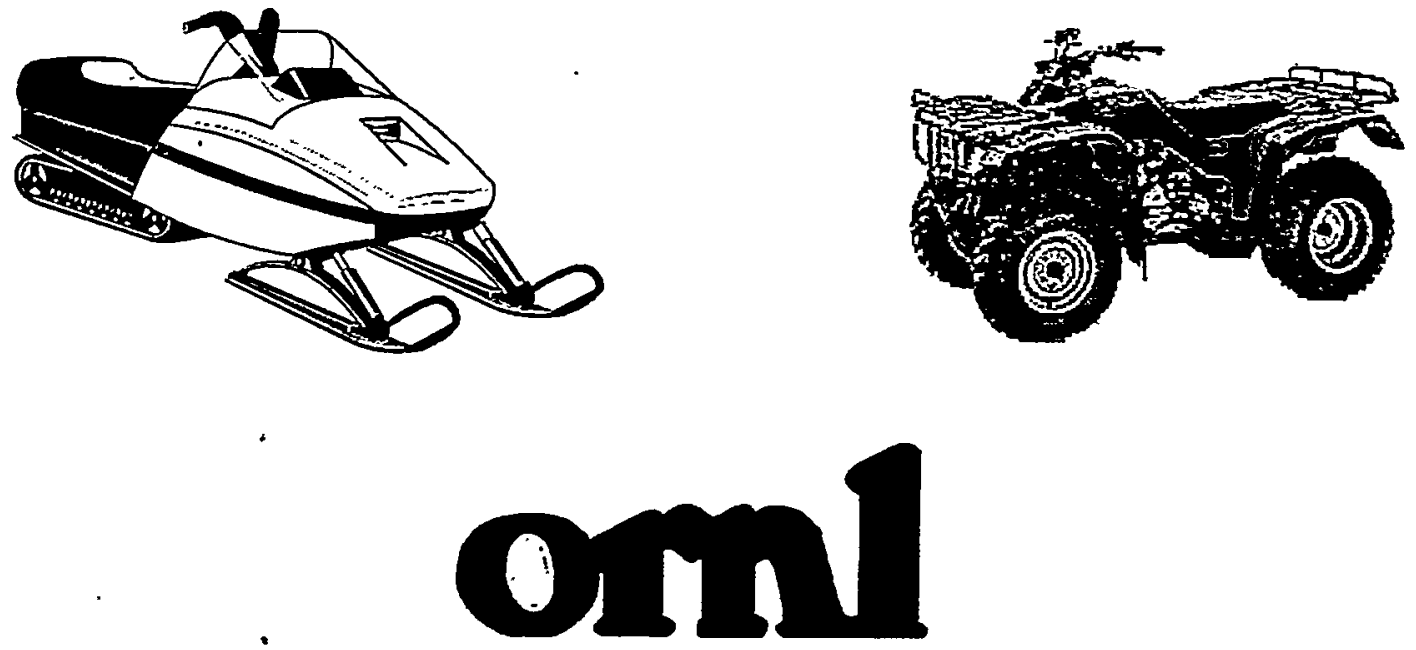


\section{DISCLAIMER}

This report was prepared as an account of work sponsored by an agency of the United States Government. Neither the United States Government nor any agency thereof, nor any of their employees, make any warranty, express or implied, or assumes any legal liability or responsibility for the accuracy, completeness, or usefulness of any information, apparatus, product, or process disclosed, or represents that its use would not infringe privately owned rights. Reference herein to any specific commercial product, process, or service by trade name, trademark, manufacturer, or otherwise does not necessarily constitute or imply its endorsement, recommendation, or favoring by the United States Government or any agency thereof. The views and opinions of authors expressed herein do not necessarily state or reflect those of the United States Government or any agency thereof. 


\section{DISCLAIMER}

Portions of this document may be illegible in electronic image products. Images are produced from the best available original document. 


\title{
Fuel Used for Off-Road Recreation: A Reassessment of the Fuel Use Model
}

\author{
Stacy C. Davis \\ Lorena F. Truett \\ Patricia S. Hu
}

July 1999

Prepared for the

Office of Highway Information Management

Federal Highway Administration

U.S. Department of Transportation

Washington, DC 20590

Prepared by the

Statistics and Data Analysis Program

Center for Transportation Analysis

Oak Ridge National Laboratory

Oak Ridge, TN 37831-6073

managed by

Lockheed Martin Energy Research Corporation

for the

U.S. Department of Energy

under

Contract No. DE-AC05-96OR22464 


\section{TABLE OF CONTENTS}

LIST OF ACRONYMS AND ABBREVIATIONS $\quad \ldots \ldots \ldots \ldots \ldots \ldots \ldots \ldots \ldots$

LIST OF TABLES $\ldots \ldots \ldots \ldots \ldots \ldots \ldots \ldots \ldots \ldots \ldots \ldots \ldots \ldots \ldots \ldots \ldots \ldots \ldots \ldots$

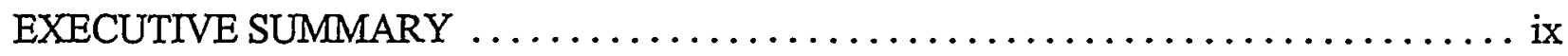

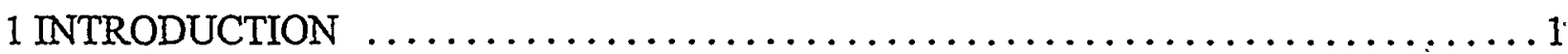

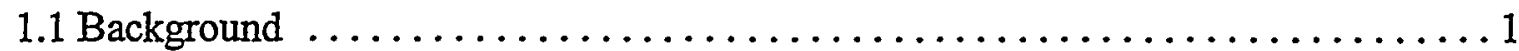

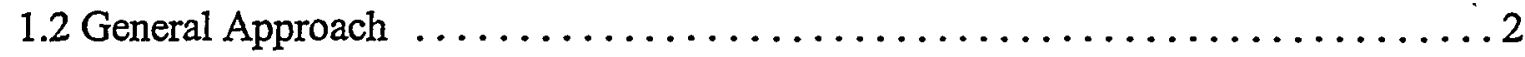

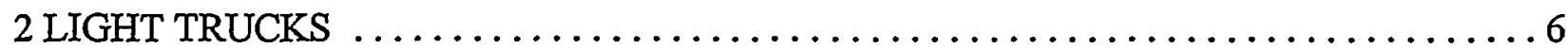

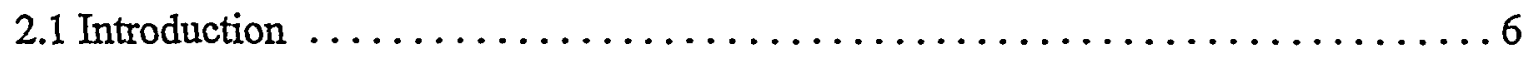

2.2 Investigation into Light Truck Fuel Use Estimation $\ldots \ldots \ldots \ldots \ldots \ldots \ldots$

2.3 Population of Off-Road Recreational Light Trucks .................. 8

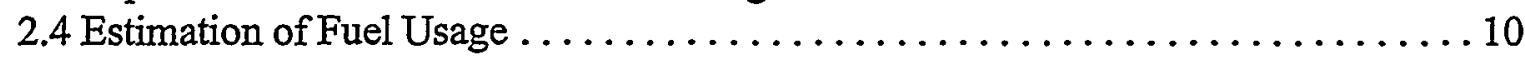

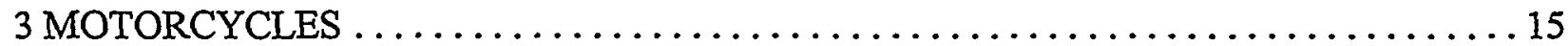

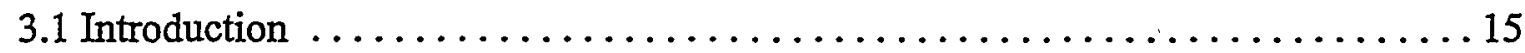

3.2 Population of Off-Road Recreational Motorcycles $\ldots \ldots \ldots \ldots \ldots \ldots \ldots \ldots \ldots$

3.3 Estimation of Fuel Usage . . . . . . . . . . . . . . . . . . . . . . . . . . 18

3.3.1 Annual mileage estimates . . . . . . . . . . . . . . . . . . . 18

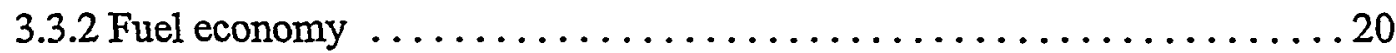

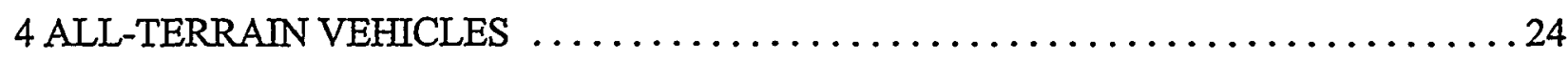

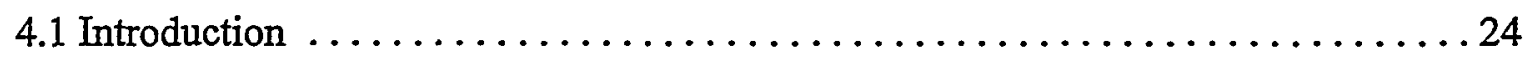

4.2 Population of Off-Road Recreational All-Terrain Vehicles $\ldots \ldots \ldots \ldots \ldots \ldots 24$

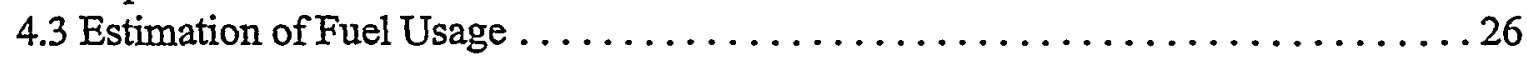

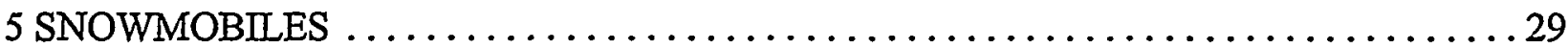

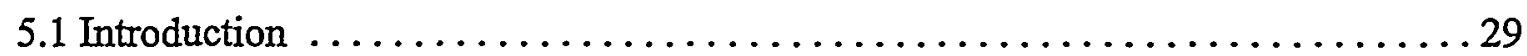

5.2 Population of Off-Road Recreational Snowmobiles $\ldots \ldots \ldots \ldots \ldots \ldots \ldots \ldots 29$

5.3 Estimation of Fuel Usage . . . . . . . . . . . . . . . . . . . . . . . . 34

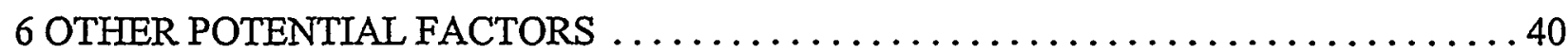

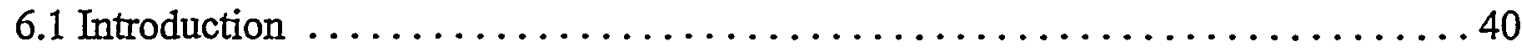

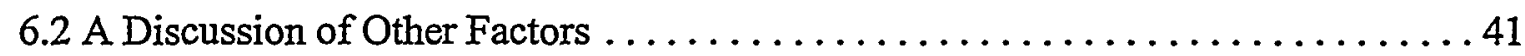

6.3 Summary and Recommendations $\ldots \ldots \ldots \ldots \ldots \ldots \ldots \ldots \ldots \ldots \ldots$

7 SUMMARY AND CONCLUSIONS $\ldots \ldots \ldots \ldots \ldots \ldots \ldots \ldots \ldots \ldots \ldots \ldots \ldots \ldots \ldots \ldots \ldots \ldots \ldots$ 


\section{TABLE OF CONTENTS (Continued)}

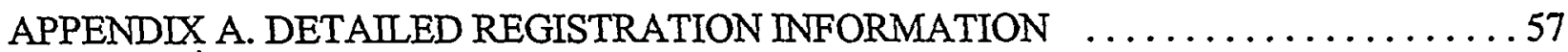

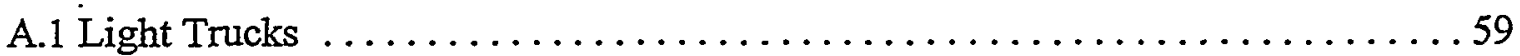

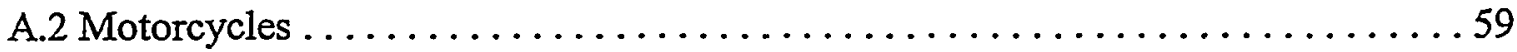

A.3 All-terrain Vehicles ...................................... 59

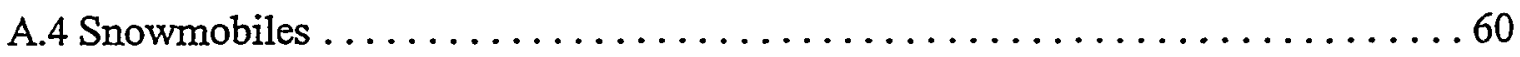

APPENDIX B. TRUCK INVENTORY AND USE SURVEY PROGRAMS $\ldots \ldots \ldots \ldots \ldots 63$ 


\section{LIST OF ACRONYMS AND ABBREVIATIONS}

$\begin{array}{ll}\text { ATV } & \text { All-terrain vehicle } \\ \text { ACSA } & \text { American Council of Snowmobile Associations } \\ \text { BLM } & \text { Bureau of Land Management } \\ \text { CARB } & \text { California Air Resources Board } \\ \text { cc } & \text { Cubic centimeter } \\ \text { CPSC } & \text { Consumer Product Safety Commission } \\ \text { DMV } & \text { Department of Motor Vehicles } \\ \text { DOT } & \text { Department of Transportation } \\ \text { EPA } & \text { Environmental Protection Agency } \\ \text { F } & \text { Fahrenheit } \\ \text { FMVSS } & \text { Federal Motor Vehicle Safety Standards } \\ \text { FHWA } & \text { Federal Highway Administration } \\ \text { FVE } & \text { Full vehicle equivalent } \\ \text { ISTEA } & \text { Intermodal Surface Transportation Efficiency Act of 1991 } \\ \text { ISIA } & \text { International Snowmobile Industry Association } \\ \text { ISMA } & \text { International Snowmobile Manufacturers Association } \\ \text { MIC } & \text { Motorcycle Industry Council } \\ \text { mpg } & \text { Miles per gallon } \\ \text { NASPD } & \text { National Association of State Park Directors } \\ \text { NCDC } & \text { National Climatic Data Center } \\ \text { NFS } & \text { National Forest Service } \\ \text { ORNL } & \text { Oak Ridge National Laboratory } \\ \text { se } & \text { Standard error } \\ \text { SVIA } & \text { Specialty Vehicle Institute of America } \\ \text { TEA-21 } & \text { Transportation Equity Act for the 21 } \\ \text { TIUS Century } & \text { Truck Inventory and Use Survey } \\ \text { VIUS } & \text { Vehicle Inventory and Use Survey } \\ \text { vmt } & \text { Vehicle miles traveled } \\ \text { USDA } & \text { U.S. Department of Agriculture } \\ & \end{array}$




\section{LIST OF TABLES}

Table 1.1 States which require some form of registration of off-highway vehicles $\ldots \ldots \ldots .4$

Table 2.1 Number of light trucks used in off-road recreation, $1997 \ldots \ldots \ldots \ldots \ldots \ldots 1$

Table 2.2 Estimation of off-road recreational light truck annual fuel use per truck, 1997 . . . 12

Table 2.3 Estimated off-road recreational light truck fuel use, $1997 \ldots \ldots \ldots \ldots \ldots \ldots . . \ldots 14$

Table 3.1 Numbers of motorcycles used off-road at some time, 1992 and 1994-1997 . . . 17

Table 3.2 Annual mileage and fuel usage estimates for motorcycles $\ldots \ldots \ldots \ldots \ldots \ldots$

Table 3.3 Estimated annual total fuel consumption for off-road motorcycles, 1997 . . . . . . 23

Table 4.1 Annual fuel consumption of ATVs used for off-road recreation, 1997 . . . . . . . 28

Table 5.1 Number of registered snowmobiles by State, $1981-1998$. . . . . . . . . . . . . 30

Table 5.2 Number of snowmobiles in States not reporting snowmobile registration

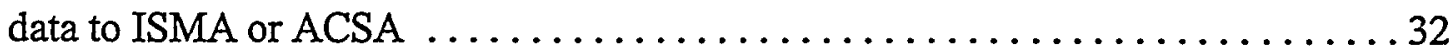

Table 5.3 Total number of snowmobiles, registered and unregistered, in each State, 1998 . . 35

Table 5.4 Categories of average annual snowfall and normal winter temperatures . . . . . . 37

Table 5.5 Estimated total fuel consumption for snowmobiles, 1998 . . . . . . . . . . . . . 39

Table 6.1 Federal Lands Acreage by State Based on U.S. National Forest Service (NFS) and Bureau of Land Management (BLM) Acreage, 1997 . . . . . . 44

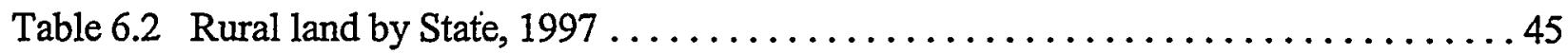

Table 7.1 Off-road fuel use estimates by vehicle type, $1997 \ldots \ldots \ldots \ldots \ldots \ldots \ldots \ldots$

Table 7.2 Categories of rural land availability for off-road recreation $\ldots \ldots \ldots \ldots \ldots \ldots$

Table 7.3 Final allocation using rural land factor adjustment $\ldots \ldots \ldots \ldots \ldots \ldots \ldots \ldots$ 
- viii -

Fuel Used for Off-Road Recreation: A Reassessment of the Fuel Use Model 


\section{EXECUTIVE SUMMARY}

The Intermodal Surface Transportation Efficiency Act of 1991 (ISTEA) established a National Recreational Trails Funding Program and the National Recreational Trails Trust Fund. ISTEA required that certain tax revenue generated from the sales of motor fuel used for off-road recreation be transferred from the Highway Trust Fund to the Trails Trust Fund for recreational trail and facility improvements. In order to apportion the Trails Trust Fund to individual States equitably, the Federal Highway Administration (FHWA) asked the Oak Ridge National Laboratory (ORNL) in 1993 to estimate the amount of motor fuel used for off-road recreation at the State level by different vehicle types. A modification of the methodology developed by ORNL has been used to apportion funds to the States since that time.

The recent surface transportation reauthorization act, the Transportation Equity Act for the 21st Century (TEA-21), extends the funding for the Recreational Trails Program for six years (from 1998 to 2003) with significant increases ${ }^{1}$. To ensure that the current method benefits from recent, more accurate data than those available in 1993-1994 and to investigate the concern that light truck recreational fuel usage is overestimated, the model previously designed by ORNL was re-evaluated, and the results of the analysis are documented in this report.

For this estimation procedure, off-road recreational fuel use is defined as Federallytaxed gasoline, gasohol, diesel fuel, or special fuel used in recreational motorized vehicles on recreational trails or back country terrain. Fuel used in outdoor nonengine recreational equipment, such as camp stoves, heaters, and lanterns, was excluded from the analysis because this fuel is not subject to the Federal motor fuel

'TEA-21 eliminated the National Recreational Trails Trust Fund, but funding apportionments to the States still require an estimate of off-highway recreational fuel use. 
excise tax. Vehicle types included in the study are light tricks (pickups and sport utility vehicles), motorcycles, all-terrain vehicles (ATVs), and snowmobiles.

As in the previous study, it was determined that a standardized estimation procedure for all States using easily obtainable and understandable data would be preferred over State-submitted reports. Reasons for this decision include incompatibility of Statesubmitted estimates, along with the fact that an estimation procedure would still be required at the Federal level for States which did not submit estimates. For this reason, individual State surveys were not heavily investigated during this effort.

A methodology for fuel use estimation was determined for each vehicle type based on the previous study and any new data sources available. Fuel use estimates rely on the population of vehicles within a State and an estimate of the average annual fuel used per vehicle. Every effort was made to include registered and non-registered vehicles. The amount of time a vehicle is used for recreational pursuits as opposed to non-recreational off-road travel was also taken into consideration.

Once the estimate of total off-road recreational fuel use was determined, the State shares were adjusted by a factor determined by the amount of rural land in the State. The adjustment was deemed necessary since vehicle registration data can be misleading for estimating fuel use by State if a vehicle travels in a different State than that in which it is registered.

After the adjustment for land usage potential was incorporated, a percentage of total fuel usage, by State, was computed. This percentage will be used in the final apportionment of funds. ORNL recommends that updated data be incorporated annually into the apportionment formula and that the percentage be recalculated each year based on these updated data. 


\section{INTRODUCTION}

\subsection{Background}

The Intermodal Surface Transportation Efficiency Act of 1991 (ISTEA) established a National Recreational Trails Funding Program and the National Recreational Trails Trust Fund. ISTEA required that certain motor fuel tax revenues generated from the sales of motor fuel for off-road recreational purposes be transferred from the Highway Trust Fund to the Trails Trust Fund for recreational trail and facility improvements. The motivation behind the Program was that while taxes were generated from sales of motor fuel used primarily for off-road recreational purposes, no commensurate benefits were received by those who made those purchases ${ }^{2}$.

Under the ISTEA, the Federal Highway Administration (FHWA) was charged with the development of State by State estimates of the amount of fuel used for off-road recreational purposes. These estimates would then be used to apportion funds available through the National Recreational Trails Funding Program to individual States. Charged with this mission, FHWA in 1993 asked the Oak Ridge National Laboratory (ORNL) to develop a method that estimates the amount of motor fuel used for off-road recreational purposes at the State level. The methodology developed by ORNL is documented in the report Fuel Used for Off-Highway Recreation (ORNL, 1994). A modification of the ORNL model was used by the FHWA from 1996 to 1999.

The recent surface transportation reauthorization act, the Transportation Equity Act for the 21st Century (TEA-21), replaced the original Trails Program with a new Recreational Trails Program. TEA-21 significantly increased the amount of funding

\footnotetext{
${ }^{2}$ The Congtess never appropriated Funds through the National Recreational Trails Trust Fund. However, funding was provided for the program from the FHWA's administrative funds in 1993, 1996, and 1997.
} 
available for the program over its six years (from 1998 to 2003). To ensure that the method for distributing program funds benefits from recent, more accurate data than those available in 1993-1994, FHWA asked ORNL to re-evaluate this model with particular emphasis on light truck recreational fuel usage because of concerns that the representation in the previous model was overestimated.

\subsection{General Approach}

For this study, as with the previous study, off-road recreational fuel use is defined as Federally-taxed gasoline, gasohol, diesel fuel, or special fuel used in recreational motorized vehicles on recreational trails or back country terrain. Both registered and unregistered recreational motorized vehicles are included insofar as the number of unregistered vehicles can be determined. Fuel used in outdoor non-engine recreational equipment, such as camp stoves, heaters, and lanterns is excluded because these fuels are not subject to the Federal motor fuel excise tax.

With a fixed amount of funding, the challenge is how to equitably apportion these funds to individual States based on the level of fuel used for off-road recreation. Two options are available to address this challenge. The first one is to rely on the individual States to submit their annual estimates on off-road recreational fuel use. The advantage of this option is that individual States could devote more resources to this activity, and can receive more cooperation in obtaining the data, than FHWA could. As a result, individual States might be able to produce more reliable estimates than FHWA could. However, more resources and more data do not guarantee more reliable estimates. The burden is then on the FHWA to verify the estimation methods employed by the individual States. This leads to three possible drawbacks if the first option is used. First, individual States may over-estimate their off-road recreational fuel use. Second, the compatibility among States in estimating off-road recreational fuel use becomes an enormous issue in trying to apportion the funds equitably. The 
third drawback of this option is that every State may not submit the required estimate. In the 1992-1993 period, only 23 States submitted data, and some of the estimates are for 1987 while others are for 1989 or 1990 . Consequently, an estimation procedure would need to be developed for the remaining 22 States that failed to submit data, adding further complexity to the compatibility issue.

To overcome the disadvantages of the first option, a second option to meet the challenge is to "standardize" the estimation procedure and develop a common tool which can objectively apportion the Recreational Trails Program funds on an annual basis. Two factors characterize this option: 1 individual State shares of the total program funds need to be developed using a uniform approach, and data needed for the estimation purpose should be publicly available and easily obtainable so that these estimates can be generated for all subsequent years. It is these two factors that govern the development of ORNL's estimation procedures, both in 1994 and in the current re-evaluation. It is also because of these two factors that ORNL's estimates are recommended over individual States' estimates. Of course, this option is not without its drawbacks. One major drawback is the failure to take advantage of more detailed State-specific information. Nonetheless, this methodology was used under ISTEA and is recommended for use under TEA-21.

In the previous methodology, as in this re-evaluation of the approach, fuel use estimates rely heavily on the population of vehicles within a State. State vehicle registration can be used in some cases, such as for light trucks (pickups and sport utility vehicles). All light trucks are required to register with each State. This is not the case with other vehicle types, such as snowmobiles, off-road motorcycles, and all-terrain vehicles (ATVs). Some States require registration, some allow optional registration, and still others require no registration of these vehicle types at all (Table 1.1 and Appendix A). In this study, every attempt was made to include 
Table 1.1. States which require some form of registration of off-highway vehicles ${ }^{1}$

\begin{tabular}{lllll}
\hline State & Light trucks & $\begin{array}{l}\text { Off-highway } \\
\text { motorcycles }\end{array}$ & ATVs & Snowmobiles \\
\hline
\end{tabular}

\begin{tabular}{|c|c|c|c|c|}
\hline Alabama & $\checkmark$ & & & \\
\hline Alaska & $\boldsymbol{v}$ & & & $\boldsymbol{v}$ \\
\hline Arizona & $\checkmark$ & & & \\
\hline Arkansas & $\checkmark$ & & $v$ & \\
\hline California & $\checkmark$ & $v^{\prime}$ & $\checkmark$ & $\checkmark$ \\
\hline Colorado & $\boldsymbol{\sim}$ & $\iota^{\prime}$ & $\boldsymbol{v}$ & $\checkmark$ \\
\hline Connecticut & $\boldsymbol{v}$ & $v^{\prime}$ & $\checkmark$ & $\checkmark$ \\
\hline Delaware & $\checkmark$ & $\omega^{\prime}$ & $\boldsymbol{v}$ & $\checkmark$ \\
\hline District of Columbia & 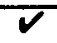 & & & \\
\hline Florida & $\checkmark$ & $v^{\prime}$ & $\checkmark$ & \\
\hline Georgia & $\checkmark$ & & & \\
\hline Hawaii & $\checkmark$ & & & \\
\hline Idaho & $\checkmark$ & 6 & $\checkmark$ & $\checkmark$ \\
\hline Illinois & $\checkmark$ & & & $\checkmark$ \\
\hline Indiana & $\boldsymbol{v}$ & $\omega^{\prime}$ & $\boldsymbol{v}$ & $\checkmark$ \\
\hline Iowa & $\checkmark$ & $\omega^{\prime}$ & $\boldsymbol{v}$ & $\boldsymbol{v}$ \\
\hline Kansas & $\checkmark$ & & & \\
\hline Kentucky & $\checkmark$ & & & \\
\hline Louisiana & $\boldsymbol{v}$ & $\omega$ & $\checkmark$ & \\
\hline Maine & $\checkmark$ & $\omega^{\prime}$ & $\boldsymbol{v}$ & $\checkmark$ \\
\hline Maryland & $\sigma$ & 6 & $\checkmark$ & $\boldsymbol{r}$ \\
\hline Massachusetts & $\checkmark$ & $\omega$ & $\boldsymbol{v}$ & $\boldsymbol{v}$ \\
\hline Michigan & $\checkmark$ & 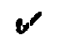 & $\boldsymbol{v}$ & $\boldsymbol{v}$ \\
\hline Minnesota & $\checkmark$ & $\omega^{\prime}$ & $\checkmark$ & $\boldsymbol{\sim}$ \\
\hline Mississippi & $\boldsymbol{V}$ & & & \\
\hline Missouri & $\boldsymbol{v}$ & & $\checkmark$ & \\
\hline Montana & $\boldsymbol{v}$ & $\omega$ & $\boldsymbol{v}$ & $\checkmark$ \\
\hline Nebraska & $\checkmark$ & & & $\checkmark$ \\
\hline Nevada & $\checkmark$ & & & \\
\hline New Hampshire & $\checkmark$ & $\omega^{\prime}$ & $\boldsymbol{v}$ & $\boldsymbol{\sigma}$ \\
\hline New Jersey & $\boldsymbol{v}$ & & $\boldsymbol{v}$ & $\checkmark$ \\
\hline New Mexico & $\boldsymbol{v}$ & $\omega$ & $\boldsymbol{v}$ & $\checkmark$ \\
\hline New York & $\checkmark$ & $m$ & $\boldsymbol{V}$ & $\sigma$ \\
\hline North Carolina & $\checkmark$ & & & \\
\hline North Dakota & $\boldsymbol{v}$ & & $\boldsymbol{v}$ & $\checkmark$ \\
\hline Ohio & $r$ & $\omega$ & $\checkmark$ & $\boldsymbol{\sim}$ \\
\hline Oklahoma & $v$ & & & \\
\hline Oregon & $\boldsymbol{v}$ & $\bullet^{\prime}$ & $\checkmark$ & $\boldsymbol{v}$ \\
\hline Pennsylvania & $\boldsymbol{v}$ & & $\checkmark$ & $\boldsymbol{\sim}$ \\
\hline Rhode Island & $\checkmark$ & $\omega$ & $\boldsymbol{v}$ & $\boldsymbol{v}$ \\
\hline South Carolina & 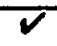 & & & \\
\hline South Dakota & $\checkmark$ & & & $\boldsymbol{v}$ \\
\hline Tennessee & $\checkmark$ & & & \\
\hline Texas & $\checkmark$ & & $\boldsymbol{v}$ & \\
\hline Utah & $\checkmark$ & 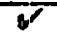 & $\checkmark$ & $\checkmark$ \\
\hline Vermont & $\boldsymbol{v}$ & $\omega$ & $\boldsymbol{v}$ & $\boldsymbol{v}$ \\
\hline Virginia & $\checkmark$ & & & \\
\hline Washington & $\boldsymbol{v}$ & $\bullet$ & $\checkmark$ & $\checkmark$ \\
\hline West Virginia & $\bar{\sigma}$ & & & \\
\hline Wisconsin & $\boldsymbol{v}$ & & $\boldsymbol{v}$ & $\checkmark$ \\
\hline Wyoming & $\checkmark$ & & & $\checkmark$ \\
\hline Total number of States & 51 & 24 & 31 & 31 \\
\hline
\end{tabular}

${ }^{1}$ Many conditions may apply to the registration, such as type of vehicle, ownership of land the vehicle is using, and length of time between registrations. See Appendix A for details on State registrations by vehicle type. 
registered as well as unregistered vehicles. Another factor considered was the amount of time these vehicles are used for recreational pursuits as opposed to nonrecreational off-road travel. In particular, light trucks, snowmobiles, and ATVs are sometimes used off-road for purposes other than recreation. And in the case of light trucks and motorcycles, adjustments are necessary for the amount of time spent offroad as opposed to on-road.

Once the recreational off-road vehicle population by State was determined for each vehicle type, estimates of annual fuel use per vehicle were used to arrive at an estimate of the total fuel used annually for each vehicle type by State. Details on the estimation of fuel use by vehicle type are contained in this report: Chapter 2 - Light Trucks; Chapter 3 -Motorcycles; Chapter 4 - ATVs; and Chapter 5 - Snowmobiles. Chapter 6 contains information on other relevant data which were investigated for inclusion in the model. Conclusions are discussed in Chapter 7. Appendix A contains information on State registration details of the different vehicle types and Appendix B contains programs used for extracting information from the 1992 Truck Inventory and Use Survey. 


\section{LIGHT TRUCKS}

\subsection{Introduction}

Light trucks are growing in popularity for

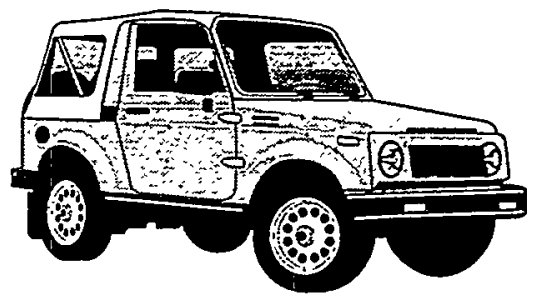
personal travel use, evidenced by a $39 \%$ growth in sales of pickups and sport utility vehicles from 1993 to 1997 (ORNL, 1999). (In this study the term light trucks refers to pickup trucks and sport utility vehicles less than 10,000 pounds gross vehicle weight.) Though many of those vehicles never leave the street, some are used to travel off-road for recreation. There are many clubs and organizations all over the nation that promote off-roading, and there is a lot of information made available about the "sport" in general. The trucks often travel over rocky, mountainous terrain, sometimes using a winch to overcome natural obstacles such as trees or rocks. In many areas there are designated trails for light trucks to use for off-road recreation.

\subsection{Investigation into Light Truck Fuel Use Estimation}

Some States have raised concerns that the light truck fuel use is overestimated in the previous off-road fuel use estimations. Light trucks represented $90 \%$ of all off-road fuel use in the latest FHWA estimates. Also, there were concerns that the fuel economy of off-road trucks as estimated by the 1987 Truck Inventory and Use Survey (TIUS) (Bureau of the Census, 1990) was too high. The light truck fuel use methodology was examined and changes were made to make use of newly available data whenever possible.

The FHWA began publishing registration data for light trucks in Highway Statistics 1966 (FHWA, 1967). Pickup trucks and sport utility vehicles could not be distinguished from other light trucks because all light trucks were reported in one category. However, beginning with Highway Statistics 1994 (FHWA, 1995), the FHWA improved the light truck registration data to include registrations by truck 
type (pickup, sport utility, van, and other). Also, the 1992 TIUS data (Bureau of the Census, 1995) are now available instead of the 1987 TIUS, which was used in the previous study.

During the investigation into the previous light truck methodology, it was discovered that there was some misleading information in the TIUS documentation, both for 1987 and 1992 data, concerning the amount of personal use of the vehicle. This was important because the amount of personal use of a truck was used to determine whether a vehicle was traveling off-road for recreational purposes as opposed to business use.

On the TIUS questionnaire (Bureau of the Census, 1992), there was a question "Which of the following best describes the way this vehicle was most often operated?" Following were five boxes which could be checked as the answer Business Use, Personal Transportation, For-Hire, Daily Rental, or Mixed. If the box marked "Mixed" was checked, there were blanks to be filled in for "Percent business use," "Percent personal use," and "Percent for-hire." Though the documentation makes no mention of it, ORNL discovered that the Census Bureau reclassified records which had an answer of "Mixed" into the other categories. The Census Bureau confirmed that only records which were exactly 50 percent personal use and 50 percent business use were left as "Mixed" in the final dataset; all other records were reclassified into whichever category had the greatest percentage (Bureau of the Census, personal communication with Stacy Davis, October 8, 1998). For instance, if someone marked "Mixed" as the answer, and wrote $40 \%$ business use and $60 \%$ personal use, the record was re-coded as "Personal Transportation" instead of "Mixed." Without this knowledge, the previous study used all records marked "Personal Transportation" to be $100 \%$ personal use. This would have included some portion of business use and excluded the personal use which was re-coded into the "Business Use" or "For-Hire" categories. 
For this study a slightly different methodology was used to determine the amount of recreational use of a light truck as opposed to business use. Because of the new understanding of the TIUS coding, the data in this study more accurately reflect the recreational use of light trucks.

The 1987 TIUS data indicated that off-road light truck fuel economy was $10 \%$ lower than that of on-road trucks. Using 1992 data the results were the same - light trucks traveling $100 \%$ off-road had a fuel economy which was $10 \%$ lower than light trucks traveling $100 \%$ on-road. In a further attempt to validate the fuel economy of off-road light trucks, the Environmental Protection Agency (EPA) Office of Mobile Sources was contacted. Unfortunately, they have no data whatsoever on off-road light trucks (EPA, Office of Mobile Sources, personal communication with R. G. Boundy, ORNL, October 1998). ORNL also contacted people from off-road organizations around the nation. As suspected, these organizations could give specific examples from their own experience but were not able to provide any national sources of information about the off-road recreation of light trucks. In the absence of any other data on the fuel economy of off-road light trucks, the 1992 TIUS data are used in this analysis.

\subsection{Population of Off-Road Recreational Light Trucks}

In order to know the off-road fuel use for light trucks, it is essential to know how many light trucks there are and what portion of them are used off-road for recreational purposes. Since the 1994 edition, FHWA's Highway Statistics publication has reported data annually on the total number of pickup truck registrations and the total number of sport utility vehicle registrations by State in Table MV-9. The task then is to determine how many of these trucks are traveling off-road and to what extent they travel off-road for recreational purposes. For this study, it is assumed that all light trucks are registered. 
It was determined that the 1992 TIUS is the best source of data on the share of light trucks used off-road for recreational purposes. TIUS is conducted by the U.S. Bureau of the Census and is required by law to be conducted every five years. The latest survey data available at the present time are the 1992 data. Within the next year, the Census Bureau will release the 1997 Vehicle Inventory and Use Survey (VIUS) (name changed from "Truck" to "Vehicle" due to future possibilities of including additional vehicle types). There are several reasons that the TIUS is a good estimator for these data. TIUS respondents were asked to provide (1) percentage of miles that the vehicle was operated off-road, and 2 the primary use of the truck (personal, business, or mixed). Respondents whose primary use of the vehicle was mixed (both business and personal) were asked to provide the percentage of business use vs. personal use. It is important to separate business use from personal use due to the fact that some off-road light truck travel is not for recreational purposes (i.e. vehicles used by the lumber industry). Information about the truck weight, body type, and configuration is also available so that pickup trucks and sport utility vehicles under 10,000 pounds gross vehicle weight can be identified.

Since TIUS did not specifically collect information on the vehicle miles used offroad for recreational purposes, ORNL assumed that the product of the percent miles used off-road and the percent personal use is a reasonable proxy of the probability that a truck will be used off-road for recreational purposes. Since light trucks travel both on-road and off-road, the number of off-road recreational light trucks is counted in full vehicle equivalents (FVE). For example, if a vehicle is driven 30 percent of its annual miles off-road for recreational purposes, then the vehicle is counted as 0.30 of a full vehicle equivalent. Thus, the number of FVE off-road recreational trucks is estimated as:

$$
{ }_{O F F} N_{j t}=\left[P U R E G_{j t} \times{ }_{P U O F F} P C T T R K_{j t}\right]+\left[{ }_{S U V} R E G_{j t} \times{ }_{\text {SUVOFF }} P C T T R K_{j t}\right],
$$


where

$$
\begin{aligned}
& { }_{\text {OFF }} N_{j t}=\text { the estimated number of full vehicle equivalents (FVE) used for } \\
& \text { off-road recreational purposes in State } j \text { in year } t \text {; } \\
& { }_{P U} R E G_{j t}=\text { the number of pickup trucks registered in State } j \text { in year } t \text {; } \\
& { }_{\text {PUOFF }} \text { PCTTRK }_{j t}=\text { the share of pickup trucks estimated to be used off-road for } \\
& \text { suv } R E G_{j t}=\text { the number of sports utility vehicles registered in State } j \text { in } \\
& \text { year } t \text {; and }
\end{aligned}
$$

See Appendix B, Program 1 for TIUS program details. Table 2.1 shows the calculation of the FVE trucks used off-road for recreational purposes. When the 1997 VIUS data become available, the light truck model should be updated by using the programs contained in Appendix B to derive new estimates.

\subsection{Estimation of Fuel Usage}

The fuel used for light truck off-road recreation can be estimated using the number of FVE trucks used off-road for recreational purposes, the fuel economy, and the annual miles per truck. The average fuel economy and average annual miles for light trucks traveling $100 \%$ off-road were compared to light trucks traveling $100 \%$ onroad. (Mixed use trucks were not taken into account in these comparisons.) Off-road trucks travel an average of $36 \%$ less on an annual basis than on-road trucks, according the TIUS data. Also, the data indicate that the average fuel economy for off-road trucks is $10 \%$ less than that of on-road trucks. (See Appendix B, Programs 2 and 3 for TIUS program details.) Using these percentages to discount the annual miles (vmt) and fuel economy (mpg), the annual gallons of fuel used per off-road truck can be estimated as: 
Table 2.1. Number of light trucks used in off-road recreation, 1997

\begin{tabular}{|c|c|c|c|c|c|}
\hline \multirow[b]{2}{*}{ State } & \multicolumn{2}{|c|}{$\begin{array}{c}1992 \text { Truck Inventory } \\
\text { and Use Survey }\end{array}$} & \multicolumn{2}{|c|}{$\begin{array}{c}\text { Highway Statistics } 1997 \\
\text { Table MV-9 }\end{array}$} & \multirow{2}{*}{$\begin{array}{l}\text { Off-road } \\
\text { light truck } \\
\text { full-vehicle } \\
\text { equivalents }\end{array}$} \\
\hline & $\begin{array}{c}\text { Share of } \\
\text { off-road } \\
\text { pickup trucks }\end{array}$ & $\begin{array}{c}\text { Share of off-road } \\
\text { sport utility } \\
\text { vehicles }\end{array}$ & $\begin{array}{c}\text { All pickup truck } \\
\text { registrations }\end{array}$ & $\begin{array}{l}\text { All sport utility } \\
\text { vehicle } \\
\text { registrations }\end{array}$ & \\
\hline & (A) & (B) & (C) & (D) & $(\mathrm{A} \times \mathrm{C})+(\mathrm{B} \times \mathrm{D})$ \\
\hline Alabama & $6.02 \%$ & $7.22 \%$ & 835,053 & 157,150 & 61,641 \\
\hline Alaska & $3.79 \%$ & $5.25 \%$ & 161,900 & 81,432 & 10,414 \\
\hline Arizona & $5.98 \%$ & $5.50 \%$ & 703,564 & 281,453 & 57,516 \\
\hline Arkansas & $8.43 \%$ & $7.05 \%$ & 518,807 & 119,544 & 52,141 \\
\hline California & $5.05 \%$ & $4.00 \%$ & $4,416,456$ & $2,006,271$ & 303,404 \\
\hline Colorado & $6.41 \%$ & $5.04 \%$ & 727,761 & 480,863 & 70,886 \\
\hline Connecticut & $2.91 \%$ & $3.62 \%$ & 270,841 & 208,081 & 15,404 \\
\hline Delaware & $6.05 \%$ & $2.51 \%$ & 82,597 & 49,381 & 6,240 \\
\hline District of Columbia & $5.24 \%$ & $5.71 \%$ & 6,254 & 10,056 & 901 \\
\hline Florida & $6.04 \%$ & $4.68 \%$ & $1,412,274$ & 732,726 & 119,584 \\
\hline Georgia & $6.08 \%$ & $5.23 \%$ & $1,271,362$ & 490,589 & 102,993 \\
\hline Hawaii . & $4.78 \%$ & $4.55 \%$ & 120,823 & 52,487 & 8,167 \\
\hline Idaho & $9.12 \%$ & $8.89 \%$ & 338,585 & 111,479 & 40,771 \\
\hline Illinois & $4.91 \%$ & $7.10 \%$ & $1,030,661$ & 514,444 & 87,079 \\
\hline Indiana & $4.17 \%$ & $2.05 \%$ & $1,036,008$ & 308,834 & 49,536 \\
\hline Iowa & $4.93 \%$ & $5.55 \%$ & 623,961 & 167,711 & 40,088 \\
\hline Kansas & $6.32 \%$ & $5.15 \%$ & 528,951 & 147,083 & 41,011 \\
\hline Kentucky & $6.81 \%$ & $4.35 \%$ & 651,379 & 165,141 & 51,527 \\
\hline Louisiana & $6.86 \%$ & $11.67 \%$ & 881,956 & 211,784 & 85,175 \\
\hline Maine & $4.56 \%$ & $5.60 \%$ & 227,122 & 77,615 & 14,697 \\
\hline Maryland & $4.15 \%$ & $3.94 \%$ & 438,562 & 274,946 & 29,030 \\
\hline Massachusetts & $3.38 \%$ & $5.68 \%$ & 464,122 & 327,652 & 34,304 \\
\hline Michigan & $3.98 \%$ & $4.63 \%$ & $1,208,774$ & 587,089 & 75,303 \\
\hline Minnesota & $4.79 \%$ & $3.50 \%$ & 741,294 & 316,849 & 46,592 \\
\hline Mississippi & $9.93 \%$ & $14.70 \%$ & 644,007 & 135,658 & 83,919 \\
\hline Missouri & $6.88 \%$ & $4.94 \%$ & 950,552 & 285,954 & 79,564 \\
\hline Montana & $6.98 \%$ & $12.66 \%$ & 308,211 & 88,822 & 32,747 \\
\hline Nebraska & $3.50 \%$ & $5.52 \%$ & 344,923 & 108,672 & 18,080 \\
\hline Nevada & $4.77 \%$ & $5.51 \%$ & 237,167 & 124,347 & 18,179 \\
\hline New Hampshire & $2.99 \%$ & $2.34 \%$ & 171,061 & 87,986 & 7,170 \\
\hline New Jersey & $8.40 \%$ & $6.91 \%$ & 412,466 & 484,496 & 68,123 \\
\hline New Mexico & $7.80 \%$ & $13.21 \%$ & 427,714 & 143,775 & 52,339 \\
\hline New York & $3.36 \%$ & $6.78 \%$ & 901,588 & 804,034 & 84,845 \\
\hline North Carolina & $5.21 \%$ & $5.14 \%$ & $1,166,351$ & 415,183 & 82,131 \\
\hline North Dakota & $5.51 \%$ & $4.78 \%$ & 177,169 & 47,399 & 12,028 \\
\hline Ohio & $5.09 \%$ & $4.82 \%$ & $1,467,370$ & 580,869 & 102,697 \\
\hline Oklahoma & $6.91 \%$ & $4.96 \%$ & 802,621 & 178,028 & 64,258 \\
\hline Oregon & $5.72 \%$ & $5.89 \%$ & 700,454 & 266,552 & 55,755 \\
\hline Pennsylvania & $3.77 \%$ & $3.83 \%$ & $1,008,489$ & 695,670 & 64,660 \\
\hline Rhode Island & $4.01 \%$ & $7.17 \%$ & 74,898 & 47,988 & 6,442 \\
\hline South Carolina & $6.05 \%$ & $5.18 \%$ & 570,856 & 193,748 & 44,584 \\
\hline South Dakota & $5.17 \%$ & $3.85 \%$ & 175,269 & 54,617 & 11,160 \\
\hline Tennessee & $4.37 \%$ & $7.81 \%$ & $1,001,666$ & 307,214 & 67,788 \\
\hline Texas & $5.90 \%$ & $4.65 \%$ & $3,074,108$ & $1,115,665$ & 233,116 \\
\hline Utah & $5.67 \%$ & $5.59 \%$ & 320,608 & 172,618 & 27,836 \\
\hline Vermont & $4.95 \%$ & $3.20 \%$ & 101,313 & 43,164 & 6,400 \\
\hline Virginia & $7.52 \%$ & $4.93 \%$ & 968,970 & 458,267 & 95,506 \\
\hline Washington & $5.30 \%$ & $6.03 \%$ & $1,033,962$ & 424,302 & 80,359 \\
\hline West Virginia & $6.86 \%$ & $4.19 \%$ & 324,211 & 105,806 & 26,663 \\
\hline Wisconsin & $3.98 \%$ & $5.60 \%$ & 715,432 & 300,450 & 45,291 \\
\hline Wyoming & $10.70 \%$ & $11.41 \%$ & 199,701 & 71,859 & 29,576 \\
\hline Total & & & $36,980,204$ & $15,623,803$ & $2,905,618$ \\
\hline
\end{tabular}




$$
\text { OFFANNGALt }=\frac{[\mathrm{ONVMT} \times(1-0.36)]}{[\mathrm{ONMPGt} \times(1-0.10)]},
$$

where

$$
\begin{aligned}
{ }_{O F F} A N N G A L_{t}= & \text { the average annual fuel use per truck for off-road recreation in } \\
& \text { year } t ; \\
{ }_{O N} V M T_{t}= & \text { the average annual miles per on-road truck in year } t ; \\
{ }_{N} M P G_{t}= & \text { the average fuel economy per on-road truck in year } t ; \\
0.36= & \text { the discount factor to adjust for off-road annual miles; and } \\
0.10= & \text { the discount factor to adjust for off-road fuel economy. }
\end{aligned}
$$

Highway Statistics Table VM-1, contains annual estimates for the average fuel economy and the average annual miles per truck for on-road light trucks. (See Table 2.2.) When the 1997 VIUS data becorne available, the light truck discount factors should be updated by using the programs contained in Appendix B to derive new estimates. Highway Statistics data was used for deriving average annual gallons per truck because it is updated annually, generally accepted, and easily understood; one drawback, however, is that they are not State-specific data.

\section{Table 2.2. Estimation of off-road recreational light truck annual fuel use per truck, 1997}

\begin{tabular}{lccc}
\hline & $\begin{array}{c}\text { Annual } \\
\text { vehicle miles } \\
\text { per truck }\end{array}$ & $\begin{array}{c}\text { Fuel economy } \\
\text { per truck }\end{array}$ & $\begin{array}{c}\text { Gallons per } \\
\text { truck }\end{array}$ \\
\cline { 2 - 4 } & $(\mathrm{A})$ & $(\mathrm{B})$ & $(\mathrm{A} \div \mathrm{B})$ \\
\hline 1997 on-road light truck data from VM-1 & 12,108 & 17.2 & 703.95 \\
1992 TIUS off-road discount percentages & $36 \%$ & $10 \%$ & \\
\cline { 2 - 3 } Estimated off-road light truck data & $7,749.12$ & 15.48 & 500.59 \\
\hline
\end{tabular}

Once the annual gallons of fuel used per truck is estimated, it can be multiplied by the number of off-road recreational truck FVE's from Table 2.1 to produce estimates 
of fuel use by State. Thus, the estimated annual fuel used by light trucks for offhighway recreational purposes is calculated as:

$$
{ }_{O F F} G A L_{j, t}={ }_{O F F} N_{j, t} \times{ }_{O F F} A N N G A L_{t},
$$

where

$$
\begin{aligned}
{ }_{\text {OFF }} G A L_{j, t}= & \text { total fuel used by light trucks in off-road recreation in State } j \text { in } \\
& \text { year } t ; \\
{ }_{\text {OFF }} N_{j, t}= & \text { the estimated number of FVE light trucks used for off-road } \\
& \text { recreational purposes in State } j \text { in year } t \text {; and } \\
{ }_{\text {OFF }} A N N G A L_{t}= & \text { the average annual fuel use per truck in year } t .
\end{aligned}
$$

Table 2.3 shows the estimated fuel used by light trucks in off-road recreation in 1997. 
Table 2.3. Estimated off-road recreational light truck fuel use, 1997

\begin{tabular}{|c|c|}
\hline$\overline{\text { State }}$ & Gallons of fuel \\
\hline Alabama & $30,856,673$ \\
\hline Alaska & $5,212,941$ \\
\hline Arizona & $28,791,650$ \\
\hline Arkansas & $26,101,369$ \\
\hline California & $151,880,913$ \\
\hline Colorado & $35,484,731$ \\
\hline Connecticut & $7,711,202$ \\
\hline Delaware & $3,123,599$ \\
\hline District of Columbia & 451,235 \\
\hline Florida & $59,862,296$ \\
\hline Georgia & $51,556,948$ \\
\hline Hawaii & $4,088,072$ \\
\hline Idaho & $20,409,470$ \\
\hline Illinois & $43,590,877$ \\
\hline Indiana & $24,797,028$ \\
\hline Iowa & $20,067,856$ \\
\hline$\overline{\text { Kansas }}$ & $20,529,419$ \\
\hline Kentucky & $25,793,937$ \\
\hline Louisiana & $42,637,561$ \\
\hline Maine & $7,357,339$ \\
\hline$\overline{\text { Maryland }}$ & $14,531,934$ \\
\hline Massachusetts & $17,172,042$ \\
\hline Michigan & $37,695,980$ \\
\hline Minnesota & $23,323,683$ \\
\hline Mississippi & $42,009,091$ \\
\hline Missouri & $39,828,793$ \\
\hline Montana & $16,392,660$ \\
\hline Nebraska & $9,050,538$ \\
\hline Nevada & $9,100,192$ \\
\hline New Hampshire & $3,589,391$ \\
\hline New Jersey & $34,101,851$ \\
\hline New Mexico & $26,200,256$ \\
\hline New York & $42,472,485$ \\
\hline North Carolina & $41,113,992$ \\
\hline North Dakota & $6,021,267$ \\
\hline Ohio & $51,408,831$ \\
\hline Oklahoma & $32,166,929$ \\
\hline Oregon & $27,910,158$ \\
\hline Pennsylvania & $32,367,925$ \\
\hline Rhode Island & $3,224,605$ \\
\hline South Carolina & $22,318,066$ \\
\hline South Dakota & $5,586,413$ \\
\hline Tennessee & $33,934,051$ \\
\hline Texas & $116,695,478$ \\
\hline Utah & $13,934,165$ \\
\hline Vermont & $3,203,522$ \\
\hline Virginia & $47,809,066$ \\
\hline Washington & $40,226,989$ \\
\hline West Virginia & $13,347,241$ \\
\hline Wisconsin & $22,672,433$ \\
\hline Wyoming & $14,805,589$ \\
\hline Total & $1,454,520,733$ \\
\hline
\end{tabular}




\section{MOTORCYCLES}

\subsection{Introduction}

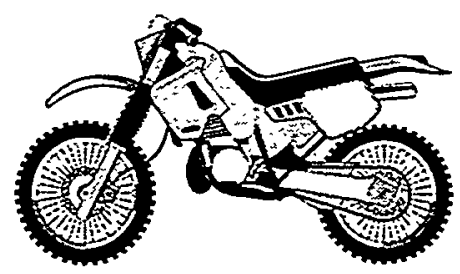

The Motorcycle Industry Council (MIC) represents manufacturers and distributors of motorcycles, scooters, and ATVs as well as members of allied trades. The MIC conducts periodic owner surveys to determine usage characteristics. The most recent survey was conducted in 1997/1998. The information collected by the MIC survey is considered proprietary and survey results are confidential. Their reproduction in this report, therefore, is limited.

The MIC also publishes an annual statistical report that lists motorcycle populations by model type, engine displacement, State, region, registrations, sales volume, etc. Registration information was obtained from the U.S. Department of Transportation, FHWA, through 1975. Though the FHWA continues to collect motorcycle registration data, the MIC statistical report has used registration data from the Motorcycle Safety Foundation, Irvine, California, since 1976. Sales information is provided by U.S. distributors. Statistics for the number of off-road bikes in the Statistical Annual are estimated from yearly sales data, from scrappage rates, and from user survey data. Additional information on estimation procedures used in the annual are provided in Section 3.2. According to the 1998 Motorcycle Statistical Annual (MIC, 1998), the South had the highest motorcycle population, approximately $28 \%$ of all motorcycles in use. The West had the highest penetration with 2.9 motorcycles per 100 persons. The average penetration over the entire United States is 2.5 bikes per 100 persons.

\subsection{Population of Off-Road Recreational Motorcycles}

Since 1985, the MIC has reported estimates of the numbers of motorcycles, by State, in the Motorcycle Statistical Annual. In this report, the MIC records off-road. 
motorcycle usage for three vehicle model categories - on-highway, dual purpose, and off-highway (off-road). Off-road motorcycles, by definition, are not certified by the manufacturer to be in compliance with Federal Motor Vehicle Safety Standards (FMVSS). Off-road motorcycles include competition motorcycles, as well as motorcycles that are ridden "just for fun" - that is, not for competition; the population of off-road motorcycles does not include ATVs. According to the MIC, about a third of all motorcycles (including those classified as "on-highway" or "dual") are used off-road at some time.

Table 3.1 provides the numbers of motorcycles used off-road at some time for 1992 and for 1994-1997 according to data supplied by the MIC. (The 1993 population of motorcycles is not included because the MIC numbers also included ATVs that year.) These State totals include all models that are classified as off-road, a percentage of those models classified as dual purpose, and a smaller percentage of those models classified as on-road. [These percentages, which are provided by the MIC in the annual report, are updated each year. For example, in 1997, 76\% of dual-purpose motorcycles and $11 \%$ of on-road motorcycles were ridden off-road at some time (MIC, 1998, p. 13).]

It should be noted that the number of motorcycles ridden off-road (Table 3.1) is assumed to equal the number of motorcycles ridden off-road at some time for recreational purposes. ORNL recognizes that this number assumes that all of these motorcycles are ridden off-road all the time, which is not true for the dual and onroad motorcycles. However, due to data limitations, the numbers given in Table 3.1 provide the best available estimation of the population of off-road motorcycles.

It is also assumed that, because the total number of motorcycles reported by the MIC is a function of retail sales and has been adjusted for unregistered vehicles, the numbers given in Table 3.1 need no further adjustment for unregistered vehicles. 
Table 3.1. Numbers of motorcycles used off-road at some time, 1992 and 1994-1997'

\begin{tabular}{|c|c|c|c|c|c|}
\hline State & $1992^{2}$ & $1994^{3}$ & $1995^{4}$ & $1996^{5}$ & $1997^{6}$ \\
\hline Alabama & 23,700 & 18,900 & 16,400 & 15,100 & 38,400 \\
\hline Alaska & 5,300 & 4,700 & 4,300 & 4,200 & 9,200 \\
\hline Arizona & 22,200 & 19,200 & 17,200 & 16,800 & 38,900 \\
\hline Arkansas & 15,400 & 12,500 & 10,800 & 9,800 & 22,800 \\
\hline Califomia & 229,800 & 198,400 & 161,800 & 148,000 & 357,600 \\
\hline Colorado & 28,400 & 24,700 & 22,700 & 22,500 & 52,000 \\
\hline Connecticut & 16,100 & 13,900 & 12,300 & 11,700 & 29,000 \\
\hline Delaware. & 3,100 & 2,800 & 2,700 & 2,500 & 5,400 \\
\hline District of Columbia & 500 & 600 & 700 & 700 & 1,000 \\
\hline Florida & 64,100 & 56,400 & 50,700 & 47,700 & 103,500 \\
\hline Georgia & 40,200 & 33,500 & 29,800 & 28,100 & 70,900 \\
\hline Hawaii & & & Data are not availabl & & \\
\hline Idaho & 21,300 & 17,600 & 15,600 & 14,400 & 34,400 \\
\hline Illinois & 40,600 & 36,400 & 33,500 & 32,300 & 68,500 \\
\hline Indiana & 27,300 & 23,800 & 21,800 & 20,900 & 47,800 \\
\hline Iowa & 13,800 & 11,400 & 10,000 & 9,500 & 21,600 \\
\hline$\overline{\text { Kansas }}$ & 10,400 & 8,600 & 7,700 & 7,200 & 16,600 \\
\hline Kentucky & 17,400 & 15,200 & 13,800 & 13,200 & 32,000 \\
\hline Louisiana & 14,300 & 11,600 & 10,600 & 10,500 & 25,400 \\
\hline Maine & 8,400 & 6,800 & 5,800 & 5,300 & 13,000 \\
\hline Maryland & 22,700 & 20,300 & 18,200 & 17,100 & 38,400 \\
\hline Massachusetts & 26,400 & 22,100 & 19,400 & 18,000 & 46,600 \\
\hline Michigan & 47,300 & 42,800 & 40,300 & 39,400 & 90,100 \\
\hline Minnesota & 23,200 & 20,400 & 18,100 & 16,900 & 37,500 \\
\hline Mississippi & 8,700 & 7,200 & 6,500 & 6,300 & 14,700 \\
\hline Missouri & 19,800 & 16,700 & 15,000 & 14,700 & 35,800 \\
\hline Montana & 12,200 & 9,600 & 8,300 & 7,500 & 18,400 \\
\hline Nebraska & 6,800 & 4,800 & 4,300 & 4,000 & 10,100 \\
\hline Nevada & 12,600 & 11,500 & 11,000 & 10,900 & 23,500 \\
\hline New Hampshire & 10,000 & 8,400 & 7,200 & 6,900 & 17,700 \\
\hline New Jersey & 33,500 & 30,100 & 26,900 & 25,400 & 60,500 \\
\hline New Mexico & 12,400 & 10,300 & 9,100 & 8,900 & 20,500 \\
\hline New York & 59,200 & 51,100 & 44,700 & 41,600 & 94,800 \\
\hline North Carolina & 39,400 & 34,600 & 31,600 & 30,700 & 75,500 \\
\hline North Dakota & 4,100 & 3,100 & 2,600 & 2,400 & 5,600 \\
\hline Ohio & 48,100 & 44,700 & 41,200 & 39,900 & 92,300 \\
\hline Oklahoma & 21,900 & 15,900 & 13,600 & 12,600 & 30,500 \\
\hline Oregon & 27,700 & 22,900 & 19,900 & 19,100 & 48,000 \\
\hline Pennsylvania & 56,800 & 50,000 & 45,200 & 43,100 & 100,200 \\
\hline Rhode Island & 4,400 & 3,700 & 3,200 & 2,800 & 7,400 \\
\hline South Carolina & 17,500 & 15,300 & 13,800 & 13,300 & 33,200 \\
\hline South Dakota & 4,700 & 3,900 & 3,300 & 3,000 & 7,100 \\
\hline Tennessee & 28,900 & 23,600 & 20,700 & 19,400 & 47,400 \\
\hline Texas & 81,900 & 67,800 & 55,500 & 51,500 & 134,100 \\
\hline Utah & 20,000 & 14,800 & 12,500 & 11,900 & 32,100 \\
\hline Vermont & 3,500 & 2,900 & 2,600 & 2,400 & 5,900 \\
\hline Virginia & 32,400 & 26,900 & 23,200 & 21,200 & 52,800 \\
\hline Washington & 46,500 & 40,400 & 35,800 & 33,500 & 78,100 \\
\hline$\overline{\text { West Virginia }}$ & 14,600 & 11,600 & 10,100 & 9,300 & 24,500 \\
\hline Wisconsin & 23,600 & 20,900 & 18,800 & 17,900 & 38,500 \\
\hline Wyoming & 5,900 & 4,700 & 4,200 & 4,000 & 9,700 \\
\hline Total & $1,379,000$ & $1,180,000$ & $1,035,000$ & 976,000 & $2,319,500$ \\
\hline
\end{tabular}

'The Motorcycle Industry Council did not supply separate numbers for motorcycles and ATVs in the 1994 report (which reported 1993 usage data).

${ }^{2}$ Motorcycle Industry Council, "1993 Motorcycle Statistical Annual," p. 28.

${ }^{3}$ Motorcycle Industry Council, "1995 Motorcycle Statistical Annual," p.12.

"Motorcycle Industry Council, "1996 Motorcycle Statistical Annual," p.13.

sMotorcycle Industry Council, "1997 Motorcycle Statistical Annual," p.13.

"Moțorcycle Industry Council, "1998 Motorcycle Statistical Annual," p.13. 


\subsection{Estimation of Fuel Usage}

In the analysis conducted in 1993-1994, ORNL examined fuel use estimates provided by four States (California, Colorado, Oregon, and Washington) and the MIC (ORNL, 1994, pp. 33-59). These fuel use estimates and the methodologies for deriving them varied widely. Using these available estimates, in 1994, ORNL gave a subjective weight to each fuel use estimate and derived low, medium, and high values for average annual fuel use. An explanation of these weights and the rationale for their selection is provided in ORNL-6794 (ORNL, 1994). This weighted average fuel consumption ranged from a low of 54 gallons per vehicle per year to a high of 64 gallons per vehicle per year for off-road consumption.

Because the MIC completed a usage survey in 1998, the current analysis looked at that data. Although summaries and summary tables will be publicly available, specific data are considered confidential and are not reported in their entirety in this report. According to MIC personnel, the questions in the survey were asked from several perspectives in order to check the consistency of the responses. Unfortunately, repeating the question from different perspectives results in large discrepancies in values for annual mileage estimates and annual fuel usage, which can be calculated in multiple ways from the survey responses.

\subsubsection{Annual mileage estimates}

For example, as shown in Table 3.2, median and mean annual mileage estimates can be derived (Method A) from a single survey question asking for an approximate number of miles ridden off-road annually. These estimates could also be derived (Method B) from responses to three different questions that request the (1) approximate number of miles ridden off-road per day, approximate number of days ridden per month, and 3 approximate number of months during which off-road 
Table 3.2. Annual mileage and fuel usage estimates for motorcycles

\begin{tabular}{|c|c|c|c|c|c|c|c|}
\hline \multirow[t]{2}{*}{1} & 2 & 3 & 4 & 5 & $\boldsymbol{6}$ & 8 & 8 \\
\hline & $\begin{array}{c}\text { Annual } \\
\text { mileage } \\
\text { estimate: } \\
\text { Method } \mathrm{A}^{1} \\
\end{array}$ & $\begin{array}{c}\text { Annual } \\
\text { mileage } \\
\text { estimate: } \\
\text { Method } \text { B }^{2}\end{array}$ & $\begin{array}{l}\text { Annual } \\
\text { mileage: } \\
\text { average of } \\
\mathrm{A} \text { and } \mathrm{B}\end{array}$ & $\begin{array}{c}\text { Days ridden } \\
\text { off-road } \\
\text { annually }\end{array}$ & $\begin{array}{l}\text { Miles per day } \\
\text { when riding } \\
\text { off-road }\end{array}$ & $\begin{array}{l}\text { Gallons of } \\
\text { gas used per } \\
\text { day of riding } \\
\text { off-road }\end{array}$ & $\begin{array}{l}\text { Annual fuel } \\
\text { usage } \\
\text { (col. } 5 \text { times } \\
\text { col. } 7 \text { ) }\end{array}$ \\
\hline Median & 100 miles & 560 miles & 330 miles & 28 days & 20 miles/day & $3.0 \mathrm{gal} /$ day & 84 gallons \\
\hline Mean & 270 miles & 1,372 miles & 821 miles & 50.4 days & 27.2 miles/day & $4.25 \mathrm{gal} /$ day & 214 gallons \\
\hline
\end{tabular}

Source: MIC, electronic communication with L. F. Truett, ORNL, March 16, 1999; data derived from the 1997/1998 MIC usage survey.

'Method A uses the responses from a single question asking how many miles were ridden in the last 12 months.

${ }^{2}$ Method B is a calculation based on responses to questions concerning the number of miles ridden per day, number of days ridden each month, and months ridden in past year; columns 5 and 6 of this table are partial components of these questions. 
recreation takes place. The mean annual mileage estimates range from 270 miles (Method A) to 1,372 miles (Method B). The median annual mileage estimates range from 100 miles (Method A) to 560 miles (Method B). MIC recommends that an average of the median estimates be used. [That is, average the median value of Method A (100 miles) and the median value of Method B (560 miles).] According to MIC personnel, "These seem to be the most 'reasonable' and 'consistent' numbers from each of the surveys" (MIC, electronic communication with L.F. Truett, ORNL, March 16, 1999). The $\mathrm{MIC}$ recommendation results in an average of 330 miles per year ridden off-road. (The average of the mean values of the two approaches results in 821 miles.) It should be noted that this methodology is not consistent with past practices, in which the MIC used the mean annual mileage estimate using Method A (270 miles).

\subsubsection{Fuel economy}

According to the MIC (MIC, 1998, p. 1), most on-road bikes have engine displacements of over $750 \mathrm{cc}$, but most dual-purpose and off-road bikes are smaller. In fact, almost $90 \%$ of off-road motorcycles in use in 1997 had engine displacements under $350 \mathrm{cc}$. In the 1994 Motorcycle Statistical Annual (MIC, 1994, p. 31 - the latest year in which motorcycle fuel economy was included), the MIC estimated that the larger bikes have an average fuel economy of about $43 \mathrm{mpg}$ and that dual-purpose motorcycles averaged between $119 \mathrm{mpg}$ (engine displacement under $125 \mathrm{cc}$ ) and $85 \mathrm{mpg}$ (engine displacement of 125-349 cc). The MIC does not publish fuel economy numbers for motorcycles used entirely off-road, and it cannot be assumed that their fuel economy would be as high as dual-purpose motorcycles, which are sometimes ridden on-road. [If one DID assume that motorcycles ridden off-road had a fuel economy of $85 \mathrm{mpg}$ and assumed that the MIC estimate of annual mileage is correct (i.e., 330 miles ridden off-road each year), then the fuel usage would be only 3.9 gallons per year ( 330 miles $\div 85 \mathrm{mpg}=3.9$ gallons)!] However, 
a fuel economy of $85 \mathrm{mpg}$ for off-road bikes is very uncertain, and this methodology is not recommended.

In the 1997/1998 usage survey, the MIC asked a survey question about the gallons of gas used per day. The median response was 3.0 gallons/day and the mean response was 4.25 gallons/day (see Table 3.2). Combining this response with responses to usage questions about the number of days ridden per year, the annual fuel usage would equate to a median value of 84 gallons of fuel used and a mean value of 214 gallons of fuel used annually. It should be noted that the fuel economy would compute to between $3.9 \mathrm{mpg}$ (median) and $3.8 \mathrm{mpg}$ (mean) for off-road motorcycle fuel consumption if these rates are combined with the median and mean annual mileage averages given above:

$$
\begin{aligned}
& 330 \text { miles } \div 84 \text { gallons }=3.9 \text { mpg; } \\
& 821 \text { miles } \div 214 \text { gallons }=3.8 \mathrm{mpg} \text {. }
\end{aligned}
$$

There is a great difference between 84 (or 214) gallons and the 3.8 gallons discussed previously. In addition, the MIC acknowledges that people responding to the survey may not really know how much fuel they use each day; they may buy fuel for more than one bike or use the fuel to clean parts or dispose of the fuel in other ways. Because of the problems with the MIC survey results, ORNL does not recommend using either 3.8, 84, or 213 gallons as the annual fuel use for off-road motorcycles. Instead, because the amount of fuel used annually in the 1994 ORNL report was well documented and seemed to be generally acceptable, ORNL recommends using the annual fuel usage estimates from the 1994 report.

Table 3.3 shows the low, medium, and high estimates for total gallons of fuel, by State, used annually for off-road recreation by motorcycles during 1997 on the basis of a fuel usage each year of 54,59 , and 64 gallons per vehicle. Until more precise data are collected on average annual fuel use of off-road motorcycles, it is 
recommended that the "medium" estimate of 59 gallons per year be used. Thus the estimated fuel use for off-road recreational motorcycles is:

$$
{ }_{o F F} G_{a l}={ }_{O F F} N_{j t} \times 59 \text { gallons , }
$$

where

$$
\begin{aligned}
{ }_{\text {oFF }} N_{j t}= & \text { the number of motorcycles used off-road some of the time in State } j \text { in } \\
& \text { year } t .
\end{aligned}
$$


Table 3.3. Estimated annual total fuel consumption for off-road motorcycles, $1997^{1}$ (gallons of fuel)

\begin{tabular}{|c|c|c|c|}
\hline State & Low estimate & Average estimate & High estimate \\
\hline$\overline{\text { Alabama }}$ & $2,073,600$ & $2,265,600$ & $2,457,600$ \\
\hline Alaska & 496,800 & 542,800 & 588,800 \\
\hline Arizona & $2,100,600$ & $2,295,100$ & $2,489,600$ \\
\hline Arkansas & $1,231,200$ & $1,345,200$ & $1,459,200$ \\
\hline California & $19,310,400$ & $21,098,400$ & $22,886,400$ \\
\hline Colorado & $2,808,000$ & $3,068,000$ & $3,328,000$ \\
\hline Connecticut & $1,566,000$ & $1,711,000$ & $1,856,000$ \\
\hline Delaware & 291,600 & 318,600 & 345,600 \\
\hline District of Columbia & 54,000 & 59,000 & 64,000 \\
\hline Florida & $5,589,000$ & $6,106,500$ & $6,624,000$ \\
\hline Georgia & $3,828,600$ & $4,183,100$ & $4,537,600$ \\
\hline Hawaii & & Data are not available & \\
\hline Idaho & $1,857,600$ & $2,029,600$ & $2,201,600$ \\
\hline Illinois & $3,699,000$ & $4,041,500$ & $4,384,000$ \\
\hline Indiana & $2,581,200$ & $2,820,200$ & $3,059,200$ \\
\hline Iowa & $1,166,400$ & $1,274,400$ & $1,382,400$ \\
\hline Kansas & 896,400 & 979,400 & $1,062,400$ \\
\hline Kentucky & $1,728,000$ & $1,888,000$ & $2,048,000$ \\
\hline Louisiana & $1,371,600$ & $1,498,600$ & $1,625,600$ \\
\hline Maine & 702,000 & 767,000 & 832,000 \\
\hline Maryland & $2,073,60,0$ & $2,265,600$ & $2,457,600$ \\
\hline Massachusetts & $2,516,400$ & $2,749,400$ & $2,982,400$ \\
\hline Michigan & $4,865,400$ & $5,315,900$ & $5,766,400$ \\
\hline Minnesota & $2,025,000$ & $2,212,500$ & $2,400,000$ \\
\hline Mississippi & 793,800 & 867,300 & 940,800 \\
\hline Missouri & $1,933,200$ & $2,112,200$ & $2,291,200$ \\
\hline Montana & 993,600 & $1,085,600$ & $1,177,600$ \\
\hline Nebraska & 545,400 & 595,900 & 646,400 \\
\hline Nevada & $1,269,000$ & $1,386,500$ & $1,504,000$ \\
\hline New Hampshire & 955,800 & $1,044,300$ & $1,132,800$ \\
\hline New Jersey & $3,267,000$ & $3,569,500$ & $3,872,000$ \\
\hline New Mexico & $1,107,000$ & $1,209,500$ & $1,312,000$ \\
\hline New York & $5,119,200$ & $5,593,200$ & $6,067,200$ \\
\hline North Carolina & $4,077,000$ & $4,454,500$ & $4,832,000$ \\
\hline North Dakota & 302,400 & 330,400 & 358,400 \\
\hline Ohio & $4,984,200$ & $5,445,700$ & $5,907,200$ \\
\hline Oklahoma & $1,647,000$ & $1,799,500$ & $1,952,000$ \\
\hline Oregon & $2,592,000$ & $2,832,000$ & $3,072,000$ \\
\hline Pennsylvania & $5,410,800$ & $5,911,800$ & $6,412,800$ \\
\hline Rhode Island & 399,600 & 436,600 & 473,600 \\
\hline South Carolina & $1,792,800$ & $1,958,800$ & $2,124,800$ \\
\hline South Dakota & 383,400 & 418,900 . & 454,400 \\
\hline Tennessee & $2,559,600$ & $2,796,600$ & $3,033,600$ \\
\hline Texas & $7,241,400$ & $7,911,900$ & $8,582,400$ \\
\hline Utah & $1,733,400$ & $1,893,900$ & $2,054,400$ \\
\hline Vermont & 318,600 & 348,100 & 377,600 \\
\hline Virginia & $2,851,200$ & $3,115,200$ & $3,379,200$ \\
\hline Washington & $4,217,400$ & $4,607,900$ & $4,998,400$ \\
\hline West Virginia & $1,323,000$ & $1,445,500$ & $1,568,000$ \\
\hline Wisconsin & $2,079,000$ & $2,271,500$ & $2,464,000$ \\
\hline Wyoming & 523,800 & 572,300 & 620,800 \\
\hline Total & $125,253,000$ & $136,850,500$ & $148,448,000$ \\
\hline
\end{tabular}

'Total annual fuel use is based on a low estimate of 54 gallons per vehicle, an average estimate of 59 gallons per vehicle, and a high estimate of 64 gallons per vehicle. See ORNL-6794, p. 54 . 


\section{ALL-TERRAIN VEHICLES}

\subsection{Introduction}

An all-terrain vehicle (ATV) is a three- or four-

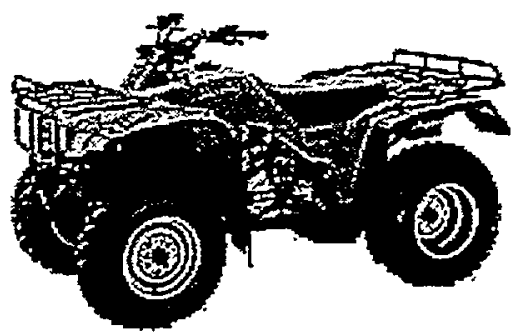
wheeled motorized vehicle designed for off-road use. In 1988, as a result of safety concerns, especially for three-wheeled ATVs, the Specialty Vehicle Institute of America (SVIA) instituted a national program to promote ATV safety (http://www.sos.state.tx.us/tac/37/1/33/33.1.html). In 1997, the Consumer Product Safety Commission (CPSC) conducted an ATV exposure survey to collect general information and to evaluate changes in usage habits pursuant to a 1989 survey on ATV safety practices (CPSC, 1998, p. 7).

The CPSC survey showed that there are approximately 3.9 million ATVs and about 5.85 million ATV drivers in the United States. Almost $60 \%$ of ATV-owning households are located in low-density areas, primarily in the midwest and south. The survey found that about $90 \%$ of ATV drivers ride on private lands at least some time and about $27 \%$ ride only on private lands (CPSC, 1998, pp. 10-13).

Engine sizes of ATVs range from about 50 to $400 \mathrm{cc}$; three-wheelers usually have engines of $250 \mathrm{cc}$ or less, and four-wheelers have engines sizes of $250 \mathrm{cc}$ or larger (CPSC, 1998, p. 16).

\subsection{Population of Off-Road Recreational All-terrain Vehicles}

The MIC represents manufacturers and distributors of motorcycles, scooters, and ATVs as well as members of allied trades. Between 1985 and 1991, the MIC collected data on the numbers of motorcycles and ATVs by State and reported combined population data in the Statistical Annual produced each year. Since 1991, the MIC has sometimes reported ATV population data separately and has sometimes 
combined it with motorcycle population data. The MIC conducted its latest usage survey in 1997/1998; however, ATV questions were not included in the survey.

State population estimates for ATVs have been computed by MIC from the annual retail sales of ATVs in conjunction with the vehicle scrappage rates, based on user survey information. In addition, the 1997 CPSC user survey information has been used to produce the current numbers of ATVs by State. This methodology for estimating State populations of ATVs is not flawless; for example, it does not consider the migration of vehicles from one State to another. It is, however, the best estimate available. Only 17 State Department of Motor Vehicles (DMVs) require registration of ATVs (see Appendix A; note that some States require registration through Recreation Management Agencies rather than through the DMVs), and there is no other survey of the population of ATVs which encompasses the entire United States. Therefore, the ATV population estimates from the MIC are used for the purposes of this report. Unfortunately, because these data are not released to the public, they cannot be printed for external circulation; therefore, they are not reproduced in this report. They were provided, however, to ORNL and to the FHWA Recreational Trails Program Office and were used to derive the ATV fuel usage, by State, for this report.

It is assumed that the numbers of ATVs, by State, as provided by the MIC are all used off-road. However, the numbers of ATVs must be adjusted for recreational use. According to the 1997 CPSC ATV exposure survey, 73.7\% [standard error (se)= 4.0] of ATV drivers use ATVs for at least one nonrecreational activity (e.g., farming or ranching, household chores, occupation, or commercial tasks). The mean time spent on non-recreational activities is 4.42 hours out of every 10 hours $(\mathrm{se}=0.30$ ). 


\subsection{Estimation of Fuel Usage}

The 1997 CPSC ATV exposure survey also contained information about annual ATV driving time in hours per year. The mean annual driving time is 252.3 hours per year ( $\mathrm{se}=35.3$ ) and the median annual driving time is 110.9 hours ( $\mathrm{se}=17.5$ ). When records for ATV drivers reporting more than 1,000 hours per year of riding time are excluded, the mean annual riding time equals 170.9 hours $(\mathrm{se}=21.2)$ per year (CPSC, 1998, p. 12). Unfortunately, ORNL has not found a method to convert driving time to fuel use.

In the analysis conducted in 1993-94, ORNL examined fuel use estimates provided by four States (California, Colorado, Oregon, and Washington) and the MIC (ORNL, 1994, pp. 33-59). These fuel use estimates and the methodologies for deriving them varied widely. Using these available estimates, in 1994, ORNL gave a subjective weight to each fuel use estimate and derived low, medium, and high values for average annual fuel use. An explanation of these weights and the rationale for their selection is provided in ORNL-67.94 (ORNL, 1994). This weighted average fuel consumption ranged from a low of 46 gallons per vehicle per year to a high of 65 gallons per vehicle per year for off-road consumption.

According to the California Air Resources Board (CARB; personal communication with Stacy Davis, ORNL, February 26, 1999), most ATVs have a fuel economy ranging between the high $40 \mathrm{~s}$ and low 50 s (i.e., $45 \mathrm{mpg}$ to $55 \mathrm{mpg}$ ).

Because the MIC did not produce new fuel economy estimates for ATVs based on the results of the 1997/1998 MIC usage survey and because the CARB values are very similar to the values used by ORNL in the previous report, ORNL used the same annual fuel estimates that were used in the previous analysis. 
Table 4.1 shows the low, medium, and high estimates for total gallons of fuel, by State, used annually for off-road recreation by ATVs during 1997 . These results have considered the non-recreational usage factor. 
Table 4.1. Annual fuel consumption of ATVs used for off-road recreation, $1997^{1}$ (gallons of fuel)

\begin{tabular}{|c|c|c|c|}
\hline State & Low estimate & Average estimate & High estimate \\
\hline Alabama & $3,233,963$ & $3,901,846$ & $4,569,730^{\circ}$ \\
\hline Álaska & $1,268,179$ & $1,530,085$ & $1,791,992$ \\
\hline Arizona & $1,646,140$ & $1,986,104$ & $2,326,068$ \\
\hline Arkansas & $3,522,599$ & $4,250,093$ & $4,977,586$ \\
\hline California & $6,324,595$ & $7,630,762$ & $8,936,928$ \\
\hline Colorado & $1,177,956$ & $1,421,229$ & $1,664,503$ \\
\hline Connecticut & 486,717 & 587,234 & 687,752 \\
\hline Delaware & 178,033 & 214,801 & 251,569 \\
\hline District of Columbia & 1,566 & 1,889 & 2,212 \\
\hline Florida & $2,889,062$ & $3,485,716$ & $4,082,370$ \\
\hline Georgia & $3,606,200$ & $4,350,959$ & $5,095,717$ \\
\hline Hawaii & & Data are not available & \\
\hline Idaho & $1,203,188$ & $1,451,672$ & $1,700,156$ \\
\hline Illinois & $2,511,254$ & $3,029,883$ & $3,548,512$ \\
\hline Indiana & $2,214,917$ & $2,672,346$ & $3,129,775$ \\
\hline Iowa & $1,200,210$ & $1,448,079$ & $1,695,949$ \\
\hline Kansas & 890,936 & $1,074,934$ & $1,258,932$ \\
\hline Kentucky & $2,763,263$ & $3,333,937$ & $3,904,611$ \\
\hline Louisiana & $3,451,140$ & $4,163,875$ & $4,876,610$ \\
\hline Maine & 921,456 & $1,111,756$ & $1,302,057$ \\
\hline Maryland & 842,398 & $1,016,372$ & $1,190,345$ \\
\hline Massachusetts & 759,105 & 915,877 & $1,072,649$ \\
\hline Michigan & $4,683,255$ & $5,650,449$ & $6,617,643$ \\
\hline Minnesota & $2,733,616$ & $3,298,168$ & $3,862,719$ \\
\hline Mississippi & $2,864,472$ & $3,456,047$ & $4,047,623$ \\
\hline Missouri & $2,996,842$ & $3,615,755$ & $4,234,668$ \\
\hline Montana & 877,563 & $1,058,799$ & $1,240,035$ \\
\hline Nebraska & 938,448 & $1,132,258$ & $1,326,067$ \\
\hline Nevada & 571,010 & 688,936 & 806,862 \\
\hline New Hampshire & 584,332 & 705,009 & 825,687 \\
\hline New Jersey & $1,193,023$ & $1,439,408$ & $1,685,793$ \\
\hline New Mexico & 672,117 & 810,923 & 949,730 \\
\hline New York & $3,656,689$ & $4,411,875$ & $5,167,060$ \\
\hline North Carolina & $3,343,719$ & $4,034,270$ & $4,724,820$ \\
\hline North Dakota & 438,435 & 528,981 & 619,528 \\
\hline Ohio & $3,688,030$ & $4,449,688$ & $5,211,346$ \\
\hline Oklahoma & $1,523,806$ & $1,838,506$ & $2,153,205$ \\
\hline Oregon & $1,746,091$ & $2,106,697$ & $2,467,303$ \\
\hline Pennsylvania & $4,422,519$ & $5,335,866$ & $6,249,212$ \\
\hline Rhode Island & 76,337 & 92,102 & 107,867 \\
\hline South Carolina & $1,375,676$ & $1,659,784$ & $1,943,891$ \\
\hline South Dakota & 511,384 & 616,995 & 722,607 \\
\hline Tennessee & $3,512,948$ & $4,238,448$ & $4,963,948$ \\
\hline Texas & $5,539,462$ & $6,683,482$ & $7,827,501$ \\
\hline Utah & $1,903,411$ & $2,296,506$ & $2,689,602$ \\
\hline Vermont & 380,810 & 459,456 & 538,102 \\
\hline Virginia & $1,851,741$ & $2,234,166$ & $2,616,590$ \\
\hline Washington & $1,568,007$ & $1,891,834$ & $2,215,662$ \\
\hline West Virginia & $2,309,581$ & $2,786,560$ & $3,263,538$ \\
\hline Wisconsin & $2,729,509$ & $3,293,212$ & $3,856,916$ \\
\hline Wyoming & 576,170 & 695,161 & 814,153 \\
\hline Total & $100,361,880$ & $121,088,790$ & $141,815,700$ \\
\hline
\end{tabular}

'Total annual fuel use is based on a low estimate of 46 gallons per vehicle, an average estimate of 55.5 gallons per vehicle, and a high estimate of 65 gallons per vehicle. See ORNL-6794, p. 54. 


\section{SNOWMOBILES}

\subsection{Introduction}

Snowmobiling is a popular recreational activity both in the United States and

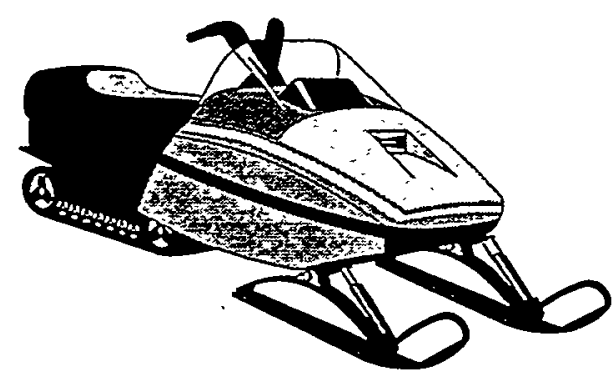
worldwide. More than half of the snowmobiles sold in 1998 were sold in the U.S, which has over 230,000 miles of groomed and marked snowmobile trails (International Snowmobile Manufacturers Association, "Snow Facts," 1998).

\subsection{Population of Off-Road Recreational Snowmobiles}

Prior to 1995, thirty-one States submitted their snowmobile registration data to the International Snowmobile Industry Association (ISIA) in response to ISIA's annual North American Snowmobile Registration Survey. In 1995, the ISIA was dissolved into two separate organizations. The American Council of Snowmobile Associations (ACSA) is a national organization for snowmobile users, and the International Snowmobile Manufacturers Association (ISMA) is an organization representing the snowmobile manufacturing industry. Since 1995, both the ACSA and the ISMA have collected registration data from the States. This collection is accomplished through phone calls to the individual States. Snowmobile registration data for 1993-1998 were obtained from ISMA.

Table 5.1 reports snowmobile registration data by State for 1981-1998 based on data supplied by ISIA (prior to 1993) and ISMA (1993 and later). Although ISIA collected data for all States, ACSA and ISMA only gather data for States that have snowmobile associations that participate in international events. Therefore, registration data previously reported for a few States with small snowmobile counts are not included in Table 5.1. These States include Connecticut, Delaware, Maryland, 
Table 5.1. Number of registered snowmobiles by State, 1981-1998

\begin{tabular}{|c|c|c|c|c|c|c|c|c|}
\hline \multirow{2}{*}{\multicolumn{9}{|c|}{$\frac{\text { State }}{\text { Alabama }}$}} \\
\hline & & & & & & & & \\
\hline Alaska & 1,102 & 2,522 & 1,602 & 2,522 & 2,632 & 3,593 & 1,812 & 2,671 \\
\hline \multicolumn{9}{|l|}{ Arizona } \\
\hline \multicolumn{9}{|l|}{ Arkansas } \\
\hline California & 5,542 & 5,048 & 5,120 & 4,816 & 5,837 & 5,729 & 6,283 & 6,847 \\
\hline Colorado & 12,832 & 14,087 & 13,959 & 13,788 & 14,250 & 13,600 & 14,234 & 15,060 \\
\hline Connecticut & 2,700 & 2,577 & 2,266 & 2,379 & 3,239 & 3,667 & 3,626 & 3,503 \\
\hline Delaware & 290 & 290 & 290 & 290 & 290 & 280 & 263 & 328 \\
\hline \multicolumn{9}{|c|}{ District of Columbia } \\
\hline \multicolumn{9}{|c|}{ Florida } \\
\hline \multicolumn{9}{|l|}{ Georgia } \\
\hline \multicolumn{9}{|l|}{ Hawaii } \\
\hline Idaho & 19,961 & 18,552 & 21,785 & 20,200 & 23,000 & 18,000 & 20,000 & 21,024 \\
\hline Illinois & 70,822 & 72,682 & 69,439 & 66,863 & 65,591 & 60,490 & 59,163 & 62,047 \\
\hline Indiana & 44,760 & 46,361 & 32,037 & 32,651 & 23,539 & 23,695 & 26,643 & 19,206 \\
\hline Iowa & 60,000 & 56,000 & 60,291 & 65,329 & 55,091 & 55,090 & 49,033 & 45,000 \\
\hline \multicolumn{9}{|l|}{ Kansas } \\
\hline \multicolumn{9}{|l|}{ Kentucky } \\
\hline \multicolumn{9}{|l|}{ Louisiana } \\
\hline Maine & 51,511 & 57,178 & 42,177 & 47,862 & 49,722 & 56,391 & 57,481 & 58,148 \\
\hline Maryland & 786 & 896 & 639 & 1,200 & 400 & 420 & 450 & 450 \\
\hline Massachusetts & 18,696 & 23,000 & 16,500 & 15,000 & 15,000 & 15,000 & 15,000 & 22,000 \\
\hline Michigan & 368,858 & 386,391 & 282,274 & 271,221 & 287,524 & 200,773 & 206,544 & 200,854 \\
\hline Minnesota & 228,764 & 220,100 & 207,564 & 202,944 & 202,944 & 198,212 & 181,598 & 192,647 \\
\hline \multicolumn{9}{|l|}{ Mississippi } \\
\hline \multicolumn{9}{|l|}{ Missouri } \\
\hline Montana & 10,944 & 14,046 & 16,074 & 13,261 & 16,569 & 12,068 & 50,589 & 50,000 \\
\hline Nebraska & 1,500 & 1,016 & 1,664 & 1,858 & 994 & 1,095 & 1,095 & 918 \\
\hline \multicolumn{9}{|l|}{ Nevada } \\
\hline New Hampshire & 26,679 & 35,490 & 21,154 & 29,658 & 30,586 & 32,974 & 38,332 & 30,000 \\
\hline New Jersey & 5,392 & 4,015 & 4,109 & 4,000 & 6,000 & 6,000 & 6,000 & 2,600 \\
\hline New Mexico & 2,543 & 3,077 & 5,900 & 4,500 & 6,000 & 6,000 & 6,000 & 7,029 \\
\hline New York & 86,907 & 85,639 & 73,244 & 67,346 & 67,346 & 60,701 & 54,321 & 56,172 \\
\hline \multicolumn{9}{|l|}{ North Carolina } \\
\hline North Dakota & 14,900 & 13,660 & 14,739 & 10,976 & 13,532 & 10,823 & 6,415 & 9,361 \\
\hline Ohio & 32,045 & 32,045 & 24,048 & 31,971 & 15,417 & 6,388 & 25,456 & 18,782 \\
\hline \multicolumn{9}{|l|}{ Oklahoma } \\
\hline Oregon & 7,544 & 7,682 & 4,113 & 8,134 & 7,813 & 8,597 & 8,767 & 9,349 \\
\hline Pennsylvania & 55,763 & 56,459 & 55,000 & 47,000 & 46,700 & 47,000 & 46,500 & 43,785 \\
\hline Rhode Island & 400 & 451 & 395 & 395 & 395 & 2,700 & 395 & 395 \\
\hline \multicolumn{9}{|l|}{ South Carolina } \\
\hline South Dakota & 4,695 & 6,986 & 7,839 & 9,617 & 9,066 & 5,163 & 6,459 & 6,433 \\
\hline \multicolumn{9}{|l|}{ Tennessee } \\
\hline \multicolumn{9}{|l|}{ Texas } \\
\hline$\overline{\text { Utah }}$ & 14,984 & 17,016 & 16,355 & 11,741 & 13,480 & 12,951 & 11,884 & 16,481 \\
\hline Vermont & 22,223 & 28,827 & 19,971 & 21,288 & 11,953 & 19,566 & 23,573 & 27,953 \\
\hline Virginia & & & & & & & & \\
\hline Washington & 14,194 & 15,161 & 14,959 & 14,959 & 17,020 & 15,813 & 17,922 & 20,032 \\
\hline West Virginia & & & & & & & & \\
\hline Wisconsin & 162,600 & 175,334 & 159,561 & 164,124 & 154,000 & 145,609 & 149,839 & 150,963 \\
\hline Wyoming & 9,468 & 12,715 & 12,972 & 12,197 & 11,136 & 11,868 & 13,736 & 14,958 \\
\hline Total & $1,359,405$ & $1,415,303$ & $1,208,040$ & $1,200,090$ & $1,177,066$ & $1,060,256$ & $1,109,413$ & $1,114,996$ \\
\hline
\end{tabular}


Table 5.1. Number of registered snowmobiles by State, 1981-1998 (continued)

\begin{tabular}{|c|c|c|c|c|c|c|c|c|c|}
\hline State & 1990 & 1991 & 1992 & 1993 & 1994 & 1995 & 1996 & 1997 & 1998 \\
\hline \multicolumn{10}{|l|}{ Alabama } \\
\hline Alaska & 2,756 & 4,427 & 4,231 & 7,181 & 7,254 & 12,366 & 9,678 & 9,678 & 12,997 \\
\hline Arizona & & & & 0 & 0 & 0 & 0 & 0 & \\
\hline \multicolumn{10}{|l|}{ Arkansas } \\
\hline California & 7,989 & 8,849 & 9,646 & 10,807 & 11,684 & 12,117 & 13,397 & 13,500 & 13,500 \\
\hline Colorado & 16,026 & 17,142 & 18,396 & 19,803 & 21,831 & 22,000 & 24,704 & 27,300 & 28,000 \\
\hline Connecticut & 3,062 & 2,635 & 2,600 & & & & & & \\
\hline Delaware & 307 & 290 & 176 & & & & & & \\
\hline \multicolumn{10}{|c|}{ District of Columbia } \\
\hline \multicolumn{10}{|l|}{ Florida } \\
\hline \multicolumn{10}{|l|}{ Georgia } \\
\hline \multicolumn{10}{|l|}{ Hawaii } \\
\hline$\overline{\text { Idaho }}$ & 15,356 & 21,000 & 22,790 & 27,255 & 27,255 & 27,005 & 31,000 & 30,861 & 35,027 \\
\hline Illinois & 60,510 & 58,891 & 58,276 & 58,112 & 58,676 & 58,676 & 60,035 & 60,000 & 58,116 \\
\hline Indiana & 22,941 & 21,509 & 18,178 & 19,179 & 17,440 & 21,341 & 18,503 & 18,506 & 19,193 \\
\hline Iowa & 22,020 & 22,000 & 29,300 & 27,000 & 31,510 & 27,000 & 26,416 & 34,594 & 33,000 \\
\hline \multirow{2}{*}{\multicolumn{10}{|c|}{$\begin{array}{l}\text { Kansas } \\
\text { Kentucky }\end{array}$}} \\
\hline & & & & & & & & & \\
\hline \multicolumn{10}{|l|}{$\begin{array}{l}\text { Kentucky } \\
\text { Louisiana }\end{array}$} \\
\hline Maine & 63,190 & 61,641 & 63,471 & 64,985 & 70,043 & 70,043 & 75,000 & 76,000 & 83,000 \\
\hline Maryland & 333 & 235 & 235 & & & & & & \\
\hline Massachusetts & 23,110 & 13,000 & 8,253 & 7,265 & 8,000 & 10,000 & 12,200 & 20,693 & 13,271 \\
\hline Michigan & 205,772 & 202,368 & 180,340 & 214,874 & 225,921 & 253,093 & 256,267 & 270,266 & 292,407 \\
\hline Minnesota & 194,339 & 191,838 & 192,926 & 205,049 & 216,928 & 216,621 & 233,433 & 270,000 & 274,913 \\
\hline \multicolumn{10}{|l|}{ Mississippi } \\
\hline Montana & 14,500 & 14,500 & 11,300 & 18,099 & 18,572 & 19,100 & 20,252 & 20,328 & 14,361 \\
\hline Nebraska & 902 & 767 & 828 & 1,182 & 1,392 & 1,392 & 1,354 & 2,000 & 1,382 \\
\hline \multicolumn{10}{|l|}{ Nevada } \\
\hline New Hampshire & 33,000 & 32,430 & 27,330 & 32,325 & 37,761 & 37,761 & 44,291 & 54,000 & 35,283 \\
\hline New Jersey & 3,641 & 2,991 & 3,000 & & & & & & \\
\hline New Mexico & 1,100 & 1,246 & 1,246 & & & & & & \\
\hline New York & 46,324 & 51,239 & 51,723 & 54,755 & 62,110 & 62,110 & 82,600 & 102,000 & 110,000 \\
\hline \multicolumn{10}{|l|}{ North Carolina } \\
\hline North Dakota & 10,893 & 8,200 & 9,200 & 9,849 & 10,393 & 14,284 & 13,095 & 17,819 & 16,201 \\
\hline Ohio & 17,947 & 18,040 & 15,421 & 17,083 & 19,783 & 19,783 & 22,153 & 22,376 & 23,000 \\
\hline \multicolumn{10}{|l|}{ Oklahoma } \\
\hline Oregon & 9,533 & 9,675 & 10,078 & 11,114 & 11,635 & 11,169 & 11,648 & 12,000 & 13,426 \\
\hline Pennsylvania & 43,000 & 39,449 & 42,354 & 34,976 & 35,300 & 35,300 & 39,658 & 45,000 & 43,000 \\
\hline Rhode Island & 432 & 375 & 353 & & & & & & \\
\hline \multicolumn{10}{|l|}{ South Carolina } \\
\hline South Dakota & 3,200 & 4,028 & 3,480 & 4,662 & 4,983 & 8,500 & 4,464 & 19,628 & 12,536 \\
\hline Tennessee & \multicolumn{9}{|c|}{ Texas } \\
\hline Utah & 12,706 & 14,034 & 9,683 & 13,436 & 20,550 & 19,920 & 22,363 & 25,706 & 24,498 \\
\hline Vermont & 33,961 & 32,762 & 31,515 & 26,337 & 27,021 & 35,996 & 32,000 & 32,600 & 26,736 \\
\hline Virginia & & & & 0 & 0 & 0 & 0 & 0 & 0 \\
\hline Washington & 17,280 & 19,631 & 20,414 & 23,179 & 27,323 & 27,323 & 24,558 & 27,539 & 27,833 \\
\hline \multicolumn{10}{|l|}{ West Virginia } \\
\hline Wisconsin & 151,000 & 155,632 & 156,062 & 164,941 & 178,624 & 179,000 & 180,216 & 200,000 & 202,216 \\
\hline Wyoming & 14,683 & 14,506 & 14,208 & 17,398 & 17,205 & 17,000 & 17,253 & 18,461 & 18,964 \\
\hline Total & $1,051,813$ & $1,045,330$ & $1,017,013$ & $1,090,846$ & $1,169,194$ & $1,218,900$ & $1,276,538$ & $1,430,855$ & $1,432,860$ \\
\hline
\end{tabular}


New Jersey, New Mexico, and Rhode Island. Explanation for snowmobile counts for these six States as well as for Alaska, Arizona, and Nevada are provided below: Table 5.2 provides the numbers of snowmobiles in States for which registration data was not available but for which snowmobile counts have been determined.

\section{Table 5.2. Number of snowmobiles in States not reporting snowmobile registration data to ISMA or ACSA}

\begin{tabular}{|c|c|c|}
\hline State & 1998 data & Source of data \\
\hline Alaska & 60,000 & $\begin{array}{l}\text { ISMA estimate for total number of snowmobiles, both registered } \\
\text { and unregistered }\end{array}$ \\
\hline Arizona & 10,000 & $\begin{array}{l}\text { ACSA estimate for total number of snowmobiles (all } \\
\text { unregistered) }\end{array}$ \\
\hline Connecticut & 1,315 & $\begin{array}{l}\text { Connecticut DMV number of registered snowmobiles in } 1997 \\
\text { (does not include unregistered vehicles) }\end{array}$ \\
\hline Delaware & 271 & $\begin{array}{l}\text { Delaware Park Resource Office number of registered } \\
\text { snowmobiles (does not include unregistered vehicles) }\end{array}$ \\
\hline Maryland & 235 & $\begin{array}{l}\text { ISIA estimate provided for } 1992 \text { (does not include unregistered } \\
\text { vehicles) }\end{array}$ \\
\hline Nevada & 0 & Nevada DMV and State Recreational Trails Office \\
\hline New Jersey & 2,513 & New Jersey Commissioner's Correspondence Unit \\
\hline New Mexico & 1,246 & $\begin{array}{l}\text { ISIA estimate provided for } 1992 \text { (does not include unregistered } \\
\text { vehicles) }\end{array}$ \\
\hline Rhode Island & 174 & Rhode Island Boat Registration and Licensing \\
\hline
\end{tabular}

The DMV and/or the State Trails Coordinators in Connecticut, Delaware, New Jersey, and Rhode Island were contacted to obtain snowmobile counts. These States were able to provide the numbers of snowmobile registrations and/or licenses (see Table 5.2).

Maryland DMV was also contacted but was unable to provide any data on the numbers of snowmobiles. New Mexico DMV stated that, in October 1998, there were 6,502 registered off-road vehicles, including off-road motorcycles, ATVs, and snowmobiles; however, New Mexico DMV could not determine how many vehicles 
belonged in each category. Since the number of off-road motorcycles as estimated by the Motorcycle Industry Council (see Chapter 4) exceeds the "total" number of off-road vehicles supplied by the New Mexico DMV, the number of registered offroad vehicles as provided by the New Mexico DMV was not used. Because current numbers of snowmobiles could not be obtained for Maryland and New Mexico, ORNL examined the growth rates of other States to see if a growth factor could be applied to the number of snowmobiles in Maryland and New Mexico based on the last known number (the value from 1992). The "growths," however, spread from $-15 \%$ (Vermont) to $260 \%$ (South Dakota). Therefore, ORNL used the last-known source of verified information - the numbers supplied by the ISIA for 1992 and set the number of snowmobiles in each of these States to the 1992 values (see Table 5.2).

Alaska has just begun requiring snowmobile registration. Although the number of registered snowmobiles for Alaska in 1998 is less than 13,000, the ISMA estimates that there is a total of 60,000 snowmobiles in Alaska and that the share that are registered will increase dramatically in the next few years. ORNL followed the guideline provided by ISMA for the total number of snowmobiles in Alaska (see Table 5.2).

Neither ISMA nor ACSA has data for Arizona, which does not require snowmobile registration. For the estimation procedure used in the 1994 allocation formula, snowmobile counts were based on surveys conducted by the State of Arizona in 1990. According to the Arizona survey, the average estimated number of snowmobiles ridden off-road in 1990 was 1,088 . No new survey of off-road recreational use has been conducted in Arizona since that time; however, the ACSA estimates that there are about 10,000 snowmobiles in Arizona (all of which are unregistered; see Table 5.2). 
Nevada has apparently never submitted registration data to ISMA or ACSA. According to the Nevada DMV, there are no requirements to register snowmobiles, and no data is available which could provide vehicle counts. Therefore, the number of snowmobiles for Nevada was set to 0 . Nevada plans to conduct a survey of offroad vehicle usage in the near future. The results of this survey should be supplied to the Federal Recreational Trails Program office for use in determining total fuel consumption for off-road recreation in future years (see Table 5.2).

Even in States that require registration, not all snowmobiles are registered. According to ISMA, the number of unregistered, usable snowmobiles in the United States is no more than $5 \%$ of the total number of snowmobiles in any State for which they have registration data, except for Alaska, which has just begun requiring registration. Most of the snowmobiles in Alaska are unregistered at this time. All snowmobiles in Arizona are unregistered. For the purpose of this analysis, the number of snowmobiles in each State (except for Alaska and Arizona, which remain constant) is increased by $5 \%$ to include unregistered usable snowmobiles. Table 5.3 provides the total number of snowmobiles by State for 1998 .

\subsection{Estimation of Fuel Usage}

In the fuel estimation procedure for snowmobiles, all snowmobiles are assumed to be used exclusively off-the-road. According to the ISMA, snowmobiles are used $80 \%$ of the time for recreation, about $15 \%$ for ice fishing, and about $5 \%$ for work purposes. Although snowmobiles do not traverse established trails to go ice fishing, this sport is a recreational activity and the fuel use will be included within the formula calculation. The annual mileage accumulated by ice fishers, however, is much lower than that of recreational trail users. This difference is accounted for in the formula. 
Table 5.3. Total number of snowmobiles, registered and unregistered, in each State, 1998

\begin{tabular}{|c|c|c|c|c|}
\hline State & $\begin{array}{c}\text { Registered } \\
\text { (source: ISMA) }\end{array}$ & $\begin{array}{c}\text { Registered } \\
\text { (other source) }\end{array}$ & $\begin{array}{l}\text { Unregistered } \\
\text { or estimated } \\
\end{array}$ & Total \\
\hline Alabama & & & & 0 \\
\hline Alaska & 12,997 & & 60,000 & 60,000 \\
\hline Arizona & 0 & & 10,000 & 10,000 \\
\hline Arkansas & & & & 0 \\
\hline Califomia & 13,500 & & 675 & 14,175 \\
\hline Colorado & 28,000 & & 1,400 & 29,400 \\
\hline Connecticut & & 1,315 & 66 & 1,381 \\
\hline Delaware & & 271 & 14 & 285 \\
\hline District of Columbia & & & & 0 \\
\hline Florida & $=$ & & & 0 \\
\hline Georgia & & & & 0 \\
\hline Hawaii & & & & 0 \\
\hline Idaho & 35,027 & & 1,751 & 36,778 \\
\hline Illinois & 58,116 & & 2,906 & 61,022 \\
\hline Indiana & 19,193 & & 960 & 20,153 \\
\hline Iowa & 33,000 & & 1,650 & 34,650 \\
\hline Kansas & & & & 0 \\
\hline Kentucky & & & & 0 \\
\hline Louisiana & & & & 0 \\
\hline Maine & 83,000 & & 4,150 & 87,150 \\
\hline Maryland & & 235 & 12 & 247 \\
\hline Massachusetts & 13,271 & & 664 & 13,935 \\
\hline Michigan & 292,407 & & 14,620 & 307,027 \\
\hline Minnesota & 274,913 & & 13,746 & 288,659 \\
\hline Mississippi & & & & 0 \\
\hline Missouri & & & & 0 \\
\hline Montana & 14,361 & - & 718 & 15,079 \\
\hline Nebraska & 1,382 & & 69 & 1,451 \\
\hline Nevada & & & & 0 \\
\hline New Hampshire & 35,283 & & 1,764 & 37,047 \\
\hline New Jersey & & 2,513 & 126 & 2,639 \\
\hline New Mexico & & 1,246 & 62 & 1,308 \\
\hline New York & 110,000 & & 5,500 & 115,500 \\
\hline North Carolina & & & & 0 \\
\hline North Dakota & 16,201 & & 810 & 17,011 \\
\hline Ohio & 23,000 & & 1,150 & 24,150 \\
\hline Oklahoma & & & & 0 \\
\hline Oregon & 13,426 & & 671 & 14,097 \\
\hline Pennsylvania & 43,000 & & $-2,150$ & 45,150 \\
\hline Rhode Island & & 174 & 9 & 183 \\
\hline South Carolina & & & & 0 \\
\hline South Dakota & 12,536 & & 627 & 13,163 \\
\hline Tennessee & & & & 0 \\
\hline Texas & & & & 0 \\
\hline$\overline{\text { Utah }}$ & 24,498 & & 1,225 & 25,723 \\
\hline Vermont & 26,736 & & 1,337 & 28,073 \\
\hline Virginia & & & & 0 \\
\hline Washington & 27,833 & & 1,392 & 29,225 \\
\hline West Virginia & & & & 0 \\
\hline Wisconsin & 202,216 & & 10,111 & 212,327 \\
\hline Wyoming & 18,964 & & 948 & 19,912 \\
\hline Total & $1,432,860$ & & & $1,566,898$ \\
\hline
\end{tabular}

'See Table 5.1.

${ }^{2}$ See Table 5.2.

${ }^{3}$ See Table 5.2. In States where snowmobiles are registered, it is assumed that an additional $5 \%$ are unregistered. This additional factor is not added to Alaska and Arizona. 
In February 1992, a survey by ISIA ("February 1992 International Snowmobile Industry Association Survey of Snowmobile Owners," data supplied to Ms An Lu, ORNL, January 13, 1993), indicated that most snowmobiles average 12.5 miles per gallon (mpg) of fuel and that the annual amount of fuel used per snowmobile is about 63 gallons. Since that time, however, snowmobiles have become more fuel efficient. In addition, because of better trails, improved machines, and warmer clothing, snowmobilers are riding further. Currently, the ISMA estimates that most snowmobiles average $15 \mathrm{mpg}$ and that the average snowmobiler riding for recreational purposes uses the snowmobile about 1,520 miles/year (ISMA, electronic communication to L. F. Truett, ORNL, November 30, 1998). Thus, the average snowmobiler uses about 101 gallons of fuel annually for "typical" off-road recreational purposes. The ISMA estimates that individuals who use their snowmobiles to go ice fishing ride for about 200 miles per year (with the same fuel economy) for a total annual fuel usage of 13.3 gallons.

Snowmobiles obviously can only travel when there is snow on the ground. Thus, snowmobile usage is a function of the amount of snow accumulated on the ground. Since there are no available data on average snow accumulation by State, average annual amount of snowfall and normal winter temperature data were used to categorize each State (Table 5.4). The snowfall ranges are a derivative of the snowfall adjustment factors from the original study, which were based on the map of mean annual snowfall published in the National Atlas of the United States of America. The temperatures are based on data from the National Climactic Data Center (NCDC) which show the maximum normal temperature in January. The NCDC derived the maximum normal temperature based on 30 years of temperature data. Maximum normal temperatures in January from the weather stations in each State were categorized as either freezing and below ( $\leq 32^{\circ}$ Fahrenheit) or above freezing $\left(>32^{\circ}\right.$ Fahrenheit). If there were data from two stations within one State, the temperatures from the stations were averaged and then classified into the 


\section{Table 5.4. Categories of average annual snowfall and normal winter temperatures}

\begin{tabular}{|c|c|c|c|}
\hline$<8$ inches of snow & $8-16$ inches of snow & $16-32 i$ & es of snow \\
\hline above $32^{\circ} \mathrm{F}$ & above $32^{\circ} \mathrm{F}$ & above $32^{\circ} \mathrm{F}$ & below $32^{\circ} \mathrm{F}$ \\
\hline Category 1 & Category 2 & Category 3 & Category 4 \\
\hline Alabama & Arizona & California & Illinois \\
\hline Arkansas & Kentucky & Dist. of Columbia & Iowa \\
\hline Florida & Missouri & Indiana & Ohio \\
\hline Georgia & North Carolina & Delaware & \\
\hline Hawaii & Oklahoma & Kansas & \\
\hline Louisiana & & Maryland & \\
\hline Mississippi & & New Jersey & \\
\hline South Carolina & & New Mexico & \\
\hline Tennessee & & Rhode Island & . \\
\hline Texas & & Virginia & \\
\hline & & West Virginia & \\
\hline
\end{tabular}

\begin{tabular}{|c|c|c|c|c|}
\hline \multicolumn{2}{|c|}{$32-64$ inches of snow } & \multicolumn{2}{|c|}{ 64-96 inches of snow } & $>96$ inches of snow \\
\hline above $32^{\circ} \mathrm{F}$ & below $32^{\circ} \mathrm{F}$ & above $32^{\circ} \mathrm{F}$ & below $32^{\circ} \mathrm{F}$ & below $32^{\circ} \mathrm{F}$ \\
\hline Category 5 & Category 6 & Category 7 & Category 8 & Category 9 \\
\hline Nebraska & Minnesota & Washington & Maine & Alaska \\
\hline Connecticut & North Dakota & Utah & Vermont & \\
\hline Colorado & Michigan & Oregon & Montana & \\
\hline Pennsylvania & Wisconsin & New York & Wyoming & \\
\hline $\begin{array}{l}\text { Massachusetts } \\
\text { Nevada }\end{array}$ & South Dakota & Idaho & New Hampshire & \\
\hline
\end{tabular}

Source: Mean annual snowfall was derived from the map of mean annual snowfall published in the National Atlas of the United States of America. Maximum normal winter temperature was derived using data from the National Climactic Data Center, Asheville, NC.

corresponding category. During the process of determining the snowfall ranges and temperatures, ORNL reviewed data from the National Climatic Data Center, the National Snow and Ice Data Center, the National Weather Service, and the USDA National Water and Climate Center.

Snowmobile fuel use adjustments were made by category to account for the difference in snowmobile usage due to the difference in opportunity for snowmobile use in the State (Table 5.4). There are ten States in category 1 which have limited opportunity for snowmobile use because of the light snowfall and warm temperatures 
(such as in Hawaii or Florida). Category 5, which is the middle category, has potential for some snowmobile use due to the amount of snowfall (32-64 inches), but warmer temperatures can prevent snow from staying for long periods. Alaska is in category 9 with the heaviest amount of snowfall and freezing winter temperatures.

The estimated annual fuel used by snowrnobiles for off-highway recreational purposes is calculated by

$$
{ }_{o F F} G a l_{j, t}=\left[\left(N_{j, \ell} \times C_{r e d}\right) \times 101 \text { gallons } \times \xi_{j}\right]+\left[\left(N_{j, t} \times C_{i c e}\right) \times 13.3 \text { gallons } \times \xi_{j}\right] \text {. }
$$

where

$$
\begin{aligned}
N_{j, t}= & \text { the number of snowmobiles, registered and unregistered, in State } j \\
& \text { in year } t ; \\
C_{r e c}= & 0.8 \text { (the percentage of the time when a snowmobile is used for } \\
& \text { "typical" recreational purposes), } \\
\left(N_{j, t} \times C_{r e d}=\right. & \text { the number of snowmobiles (in full vehicle equivalents) used for } \\
& \text { off-road recreation, } \\
C_{i c e}= & 0.15 \text { (the percentage of the time when a snowmobile is used for ice } \\
& \text { fishing), } \\
\left(N_{j, t} \times C_{i c e}\right)= & \text { the number of snowmobiles (in full vehicle equivalents) used for } \\
& \text { ice fishing, and } \\
\zeta_{j}= & \text { the adjustment factor for State } j \text { in terms of the difference in the } \\
& \text { amount of snowfall and temperature (Table 5.4). }
\end{aligned}
$$

The resulting fuel use estimates are in Table 5.5. 
Table 5.5. Estimated total fuel consumption for snowmobiles, 1998

\begin{tabular}{|c|c|c|c|c|}
\hline State & $\begin{array}{c}\text { Number of } \\
\text { snowmobiles }\end{array}$ & $\begin{array}{l}\text { Average annual } \\
\text { fuel use for } \\
\text { recreation (gal.) }\end{array}$ & $\begin{array}{l}\text { Average annual } \\
\text { fuel use for } \\
\text { ice fishing (gal.) }\end{array}$ & $\begin{array}{l}\text { Total fuel } \\
\text { used (gal.) }\end{array}$ \\
\hline Alabama & 0 & 0 & 0 & 0 \\
\hline Alaska & 60,000 & $7,376,941$ & 182,141 & $7,559,082$ \\
\hline Arizona & 10,000 & 153,686 & 3,795 & 157,481 \\
\hline Arkansas & 0 & 0 & 0 & 0 \\
\hline California & 14,175 & 435,701 & 10,758 & 446,458 \\
\hline Colorado & 29,400 & $1,807,350$ & 44,625 & $1,851,975$ \\
\hline Connecticut & 1,381 & 84,881 & 2,096 & 86,977 \\
\hline Delaware & 285 & 8,746 & 216 & 8,962 \\
\hline District of Columbia & 0 & 0 & 0 & $\overline{0}$ \\
\hline Florida & 0 & 0 & 0 & 0 \\
\hline Georgia & 0 & 0 & 0 & 0 \\
\hline Hawaii & 0 & 0 & 0 & 0 \\
\hline Idaho & 36,778 & $3,391,396$ & 83,736 & $3,475,132$ \\
\hline Illinois & 61,022 & $2,813,464$ & 69,466 & $2,882,930$ \\
\hline Indiana & 20,153 & 619,437 & 15,294 & 634,731 \\
\hline Iowa & 34,650 & $1,597,569$ & 39,445 & $1,637,014$ \\
\hline Kansas & 0 & 0 & 0 & 0 \\
\hline Kentucky & 0 & 0 & 0 & 0 \\
\hline Louisiana & 0 & 0 & 0 & 0 \\
\hline Maine & 87,150 & $9,375,631$ & 231,490 & $9,607,120$ \\
\hline Maryland & 247 & 7,584 & 187 & 7,772 \\
\hline Massachusetts & 13,935 & 856,620 & 21,150 & 877,770 \\
\hline Michigan & 307,027 & $23,592,943$ & 582,524 & $24,175,467$ \\
\hline Minnesota & 288,659 & $22,181,435$ & 547,673 & $22,729,108$ \\
\hline Mississippi & 0 & 0 & 0 & 0 \\
\hline Missouri & 0 & 0 & 0 & 0 \\
\hline Montana & 15,079 & $1,622,210$ & 40,053 & $1,662,263$ \\
\hline Nebraska & 1,451 & 89,206 & 2,203 & 91,408 \\
\hline Nevada & 0 & 0 & 0 & 0 \\
\hline New Hampshire & 37,047 & $3,985,547$ & 98,406 & $4,083,952$ \\
\hline New Jersey & 2,639 & 81,105 & 2,003 & 83,107 \\
\hline New Mexico & 1,308 & 40,214 & 993 & 41,206 \\
\hline New York & 115,500 & $12,425,534$ & 306,794 & $12,732,328$ \\
\hline North Carolina & 0 & 0 & 0 & 0 \\
\hline North Dakota & 17,011 & $1,307,182$ & 32,275 & $1,339,457$ \\
\hline Ohio & 24,150 & $1,113,457$ & 27,492 & $1,140,949$ \\
\hline Oklahoma & 0 & 0 & 0 & 0 \\
\hline Oregon & 14,097 & $1,299,937$ & 32,096 & $1,332,033$ \\
\hline Pennsylvania & 45,150 & $2,775,574$ & 68,531 & $2,844,104$ \\
\hline Rhode Island & 183 & 5,616 & 139 & 5,754 \\
\hline South Carolina & 0 & 0 & 0 & 0 \\
\hline South Dakota & 13,163 & $1,011,471$ & 24,974 & $1,036,445$ \\
\hline Tennessee & 0 & 0 & 0 & .0 \\
\hline Texas & 0 & 0 & 0 & 0 \\
\hline$\overline{\text { Utah }}$ & 25,723 & $2,371,954$ & 58,565 & $2,430,519$ \\
\hline Vermont & 28,073 & $3,020,083$ & 74,568 & $3,094,650$ \\
\hline Virginia & 0 & 0 & 0 & 0 \\
\hline Washington & 29,225 & $2,694,856$ & 66,538 & $2,761,394$ \\
\hline West Virginia & 0 & 0 & 0 & 0 \\
\hline Wisconsin & 212,327 & $16,315,856$ & 402,848 & $16,718,704$ \\
\hline Wyoming & 19,912 & $2,142,162$ & 52,891 & $2,195,053$ \\
\hline Total & $1,566,898$ & $126,605,346$ & $3,125,961$ & $129,731,307$ \\
\hline
\end{tabular}

${ }^{1}$ Includes both registered and unregistered vehicles. 
Fuel Used for Off-Road Recreation: A Reassessment of the Fuel Use Model

6 OTHER POTENTIAL FACTORS

\subsection{Introduction}

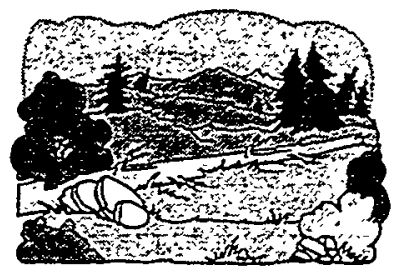

Off-road vehicles use recreational trails or back country terrain. Off-road clubs, associations, and other organizations abound and include enthusiasts for motorcycles, ATVs, snowmobiles, $4 \times 4 s$, sand cars, quads, etc. According to the Environmental Protection Agency (EPA), "Increasing numbers of Americans are taking to the back country, and more and more are doing so on wheels. Use of off-road motorcycles and all-terrain vehicles nearly tripled between 1980 and 1990" (http://www.epa.gov/owowwtr1/info/NewsNotes/issue40/nps40nat.html).

In earlier chapters of this report, we provided rationale for deriving the population of each type of off-road recreational vehicle (light trucks, motorcycles, ATVs, and snowmobiles) by State and also for calculating the total fuel used for off-road recreational purposes. The end result of each of these chapters was the number of gallons of off-road fuel used for recreational purposes, by State, for each type of offroad vehicle. The process included counting the number of vehicles within each category and multiplying that number by the annual fuel usage for one vehicle of that category.

It has been suggested that calculating fuel consumption based on a count of off-road recreational vehicles in a State is not necessarily a fair measure since, for example, a light truck (or a motorcycle, ATV, or snowmobile) might be registered in (or belong to a resident of) one State but ridden off-road in a different State. To address this concern, ORNL considered other possible factors. 


\subsection{A Discussion of Other Factors}

Additional factors that could impact the calculation of the amount of off-road recreational fuel used include the following:

- Visitation to Federal recreation areas, as measured in number of visitors, visitation hours, or visitor days,

- Recreational use of public land for off-road vehicle travel, as measured in visitor hours,

- Miles of trail available for off-road usage by motorized vehicles,

- Private land available for off-road usage by motorized vehicles,

- State land available for off-road usage by motorized vehicles,

- Federal land́ available for off-road usage by motorized vehicles, and

- Rural land available for off-road usage by motorized vehicles.

Each of these potential factors is discussed below.

The Statistical Abstract of the United States 1997 (Bureau of the Census, 1997) provides data on visitations to Federal recreational areas (in number of visitors, visitor hours, or visitor days) and lists the recreational use of public lands for off-road vehicle travel (in visitor hours). In addition, the Bureau Recreation Management Information System Report \#22 provides information of visitor use activities based on participant, visitor hours, and visitor days. One category that is measured is "Trail activities." These measures of recreational use seem to be potential factors for inclusion in the formula for recreational fuel use. Unfortunately, the measurement of off-road vehicle travel is provided for only a few individual States and groupings of the remaining States. When event participation is measured and provided for every individual State, the measurement includes activities other than just off-road vehicle recreation. Therefore, because of these limitations, these potential factors are not recommended for use at this time. 
The existence of trails and/or the accessibility of acreage definitely encourages recreational participation. Arriving at a fair and equitable measure of length of trails and/or acreage is not simple, however.

For example, although some States have very precise measurements of miles of established trails, other States have not calculated the miles of trail available to offroad vehicles. In some areas, ATVs are used by hunters, and many of their trails are logging roads on private land. Therefore, a source of data which measures the miles of "trail" in each State in an equitable manner is difficult or perhaps impossible to obtain. For this reason, using miles of trail as a proxy for off-road recreation is not recommended at this time.

Measuring acreage that allows use of ORVs is another potential option for calculating off-road recreational activities.

One type of land that is made available for off-road recreational use is privately owned property (e.g., large tracts of land belonging to timber companies). Sometimes this land is leased and managed by a State; sometimes it is just made available to individual off-road clubs and associations. A few States have estimates of the amount of land that is available; however, there is little or no consistency on how the information is obtained by the States, on how long the private lands are available for off-road vehicle usage, or on specific restrictions that are applied (e.g., only available during hunting season). Because there is no verifiable, stable data source for the amount of private land available for off-road recreation, this factor is not recommended at this time.

ORNL attempted to obtain acreages for State-owned properties available in each State for recreational purposes. Land totals were calculated from information obtained from the National Association of State Park Directors (NASPD). These 
acreages included recreation areas, State forests, and fish/wildlife areas but excluded State parks, natural areas, historic areas, environmental education areas, scientific areas, and other miscellaneous areas, because these areas generally prohibited offroad vehicles. The total acreages were sent to the Recreational Trails Coordinators in each State for validation. Although a few States verified these numbers, most States rejected them as incorrect and supplied other numbers (almost always greater). In addition, some States never responded to the request to supply better numbers. Because there is no central valid source of data for State land that is accessible to offroad vehicles, use of State acreage is not recommended at this time.

Table 6.1 provides a total acreage of Federal lands available in each State. This acreage is a sum of all non-wilderness land managed by either the U.S. National Forest Service (NFS) or the Bureau of Land Management (BLM). Because there are valid central sources of NFS and BLM data and because the existence of public land that permits off-road vehicle usage is an indication of the potential for off-road recreational fuel use, using Federal, non-wilderness acreage within the formula seems to be a valid practice. This land measure, however, does not include all available recreational areas (e.g., State and private lands that allow motorized recreation are excluded). Therefore, it is incomplete.

The final factor examined is that of net rural land area. Table 6.2 shows this measurement for square miles (as given in Highway Statistics 1997, TablePS-1). The rationale for selecting net rural land area as a proxy for availability of land for offroad recreational fuel use includes the following: 1 it is a number supplied by the States to FHWA, the definitions for "rural" and "urban" areas are clearly defined, easily understood, and consistently applied, 3 it includes Federal, State, and private rural lands, and 4 the data are from a stable, accessible source that is updated regularly. 
Table 6.1. Federal lands acreage by State based on U.S. National Forest Service (NFS) and Bureau of Land Management (BLM) acreage, 1997

\begin{tabular}{|c|c|c|c|c|c|}
\hline State & $\begin{array}{l}\text { NFS } \\
\text { land }\end{array}$ & $\begin{array}{l}\text { NFS wildemess } \\
\text { land }\end{array}$ & $\begin{array}{l}\text { BLM } \\
\text { land }\end{array}$ & $\begin{array}{l}\text { BLM wilderness } \\
\text { land }\end{array}$ & $\begin{array}{c}\text { Total NFS +BLM } \\
\text { non-wilderness land }\end{array}$ \\
\hline Alabama & 664,889 & 32,167 & 3,117 & 0 & 635,839 \\
\hline Alaska & $21,969,321$ & $5,752,298$ & $86,908,060$ & 0 & $103,125,083$ \\
\hline Arizona & $11,251,701$ & $1,345,008$ & $11,609,999$ & $1,405,750$ & $20,110,942$ \\
\hline Arkansas & $2,576,852$ & 116,578 & 2,059 & 0 & $2,462,333$ \\
\hline California & $20,647,142$ & $4,432,634$ & $9,088,886$ & $3,587,381$ & $21,716,013$ \\
\hline Colorado & $14,508,108$ & $3,147,101$ & $7,262,065$ & 59,255 & $18,563,817$ \\
\hline Connecticut & 24 & 0 & 0 & 0 & 24 \\
\hline Delaware & 0 & 0 & 0 & 0 & 0 \\
\hline District of Columbia & $\overline{0}$ & $\overline{0}$ & 0 & 0 & 0 \\
\hline Florida & $1,147,246$ & 74,495 & 1,512 & 0 & $1,074,263$ \\
\hline Georgia & 864,942 & 114,537 & 0 & 0 & 750,405 \\
\hline Hawaii & 1 & 0 & 0 & 0 & 1 \\
\hline Idaho & $20,460,774$ & $3,961,578$ & $11,155,662$ & 802 & $27,654,056$ \\
\hline Illinois & 277,506 & 25,638 & 3 & 0 & 251,871 \\
\hline Indiana & 195,625 & 12,945 & 0 & 0 & 182,680 \\
\hline lowa & 0 & 0 & 0 & 0 & 0 \\
\hline$\overline{\text { Kansas }}$ & 108,175 & 0 & 0 & 0 & 108,175 \\
\hline Kentucky & 693,126 & 16,779 & 0 & 0 & 676,347 \\
\hline Louisiana & 604,138 & 8,679 & 4,351 & 0 & 599,810 \\
\hline Maine & 53,040 & 12,000 & 0 & 0 & 41,040 \\
\hline Maryland & 0 & $\overline{0}$ & 0 & 0 & 0 \\
\hline Massachusetts & 0 & 0 & 0 & 0 & 0 \\
\hline Michigan & $2,857,019$ & 91,891 & 47 & 0 & $2,765,175$ \\
\hline Minnesota & $2,837,488$ & 809,772 & 6,044 & 0 & $2,033,760$ \\
\hline$\overline{\text { Mississippi }}$ & $1,158,172$ & 6,046 & 1,240 & 0 & $1,153,366$ \\
\hline Missouri & $1,494,217$ & 63,198 & 67 & 0 & $1,431,086$ \\
\hline Montana & $16,877,005$ & $3,371,881$ & $6,089,123$ & 6,000 & $19,588,247$ \\
\hline Nebraska & 352,133 & 7,794 & 6,580 & 0 & 350,919 \\
\hline Nevada & $5,823,676$ & 787,085 & $47,633,965$ & 6,435 & $52,664,121$ \\
\hline New Hampshire & 724,740 & 102,932 & 0 & 0 & 621,808 \\
\hline New Jersey & 0 & 0 & 0 & 0 & 0 \\
\hline New Mexico & $9,326,935$ & $1,388,262$ & $12,402,742$ & 145,425 & $20,195,990$ \\
\hline$\overline{\text { New York }}$ & 16,068 & $\overline{0}$ & 0 & 0 & 16,068 \\
\hline North Carolina & $1,243,520$ & 102,634 & 0 & 0 & $1,140,886$ \\
\hline North Dakota & $1,105,752$ & 0 & 59,536 & 0 & $1,165,288$. \\
\hline Ohio & 227,187 & 0 & 0 & 0 & 227,187 \\
\hline Oklahoma & 392,211 & 14,543 & 2,142 & 0 & 379,810 \\
\hline Oregon & $15,656,351$ & $2,072,494$ & $13,040,775$ & 6,788 & $26,617,844$ \\
\hline Pennsylvania & 513,264 & 8,938 & 0 & 0 & 504,326 \\
\hline Rhode Island & 0 & 0 & 0 & 0 & 0 \\
\hline South Carolina & 612,390 & 16,671 & 0 & 0 & 595,719 \\
\hline South Dakota & $2,013,124$ & 9,826 & 272,277 & 0 & $2,275,575$ \\
\hline Tennessee & 634,073 & 66,349 & 0 & 0 & 567,724 \\
\hline Texas & 754,983 & 38,483 & 0 & 0 & 716,500 \\
\hline$\overline{\text { Utah }}$ & $8,112,730$ & 773,818 & $21,155,026$ & 26,630 & $28,467,308$ \\
\hline Vermont & 366,406 & 59,421 & 0 & 0 & 306,985 \\
\hline Virginia & $1,656,986$ & 87,064 & 0 & 0 & $1,569,922$ \\
\hline Washington & $9,177,071$ & $2,572,977$ & 366,921 & 6,900 & $6,964,115$ \\
\hline West Virginia & $1,032,625$ & 80,852 & 0 & 0 & 951,773 \\
\hline Wisconsin & $1,521,104$ & 42,294 & 2,521 & 0 & $1,481,331$ \\
\hline Wyoming & $9,247,742$ & $3,111,232$ & $15,184,488$ & 0 & $21,320,998$ \\
\hline Total & $191,757,582$ & $34,738,894$ & $242,259,208$ & $5,251,366$ & $394,026,530$ \\
\hline
\end{tabular}

Sources:

NFS acreage - "Land Areas of the National Forest System, as of September 1997," Table 4, Areas by States, http://www.fs.fed.us/database/lar/97. NFS Wilderness acreage - "Land Areas of the National Forest System, as of September 1997," Table 9, National Wilderness Areas Summary, http://www.fs.fed.us/database/lar/97. BLM acreage - Public Land Statistics 1997, Table 1-4, Public Lands Under Exclusive Jurisdiction of the Bureau of Land Management, Fiscal Year 1997, http://www.blm.gov/natacq/pls97. BLM Wilderness acreage Public Land Statistics 1997, Table 5-10, Bureau ofLand Management lands designated as wilderness by Congress as of September 30, 1997, http://www.blm.gov/natacq/pls97. 
Table 6.2. Rural land by State, 1997

\begin{tabular}{|c|c|}
\hline State & $\begin{array}{c}1997 \\
\text { Rural net } \\
\text { land area } \\
\text { (square miles) }\end{array}$ \\
\hline Alabama & 47,561 \\
\hline Alaska & 569,444 \\
\hline Arizona & 110,757 . \\
\hline Arkansas & 51,096 \\
\hline California & 146,692 \\
\hline Colorado & 101,942 \\
\hline Connecticut & 3,287 \\
\hline Delaware & 1,677 \\
\hline District of Columbia & 0 \\
\hline Florida & 45,477 \\
\hline Georgia & 54,389 \\
\hline Hawaii & 6,159 \\
\hline Idaho & 82,284 \\
\hline Illinois & 51,484 \\
\hline Indiana & 34,004 \\
\hline lowa & 54,761 \\
\hline Kansas & 80,642 \\
\hline Kentucky & 38,340 \\
\hline Louisiana & 41,428 \\
\hline Maine & 30,383 \\
\hline Maryland & 8,114 \\
\hline Massachusetts & 4,788 \\
\hline Michigan & 53,250 \\
\hline Minnesota & 77,778 \\
\hline Mississippi & 45,856 \\
\hline Missouri & 66,884 \\
\hline Montana & 145,290 \\
\hline Nebraska & 76,444 \\
\hline Nevada & 108,943 \\
\hline New Hampshire & 8,506 \\
\hline New Jersey & 5,040 \\
\hline New Mexico & 120,810 \\
\hline New York & 41,761 \\
\hline North Carolina & 45,488 \\
\hline North Dakota & 68,841 \\
\hline Ohio & 36,474 . \\
\hline Oklahoma & 66,650 \\
\hline Oregon & 95,056 \\
\hline Pennsylvania & 40,869 \\
\hline Rhode Island & 517 \\
\hline South Carolina & 28,686 \\
\hline South Dakota & 75,648 \\
\hline Tennessee & 38,484 \\
\hline Texas & 253,449 \\
\hline Utah & 81,301 \\
\hline Vermont & 9,020 \\
\hline Virginia & 37,118 \\
\hline Washington & 64,359 \\
\hline West Virginia & 23,656 \\
\hline Wisconsin & 52,869 \\
\hline Wyoming & 96,625 \\
\hline Total & $3,430,381$ \\
\hline
\end{tabular}


It should be noted, however, that the availability of land for off-road recreation does not ensure off-road recreational fuel use. Therefore, ORNL does not recommend that this factor be incorporated directly into the formula. The methodology that ORNL recommends for applying this land-based data is explained in Chapter 7.

\subsection{Summary and Recommendations}

In this chapter, we examined several new potential factors that might impact the amount of fuel used for off-road recreation. These factors included time-based and land-based measures.

While researching the existence of data sets that are believable, dependable, stable, updated on a reasonable basis, accessible by FHWA, and consistently applied across all States, ORNL requested information from State DOTs, State Trails Coordinators, and other agencies and organizations. In responding to a request for information, one State recommended that a scientifically designed study be conducted among all States. While surveys on recreational fuel use have been conducted within individual States in the past, they have used various survey methodologies. Surveys that are not applied consistently across all States can not serve the same purpose as a. single survey that is statistically designed and universally applied. A survey collecting data consistently over all States could ascertain off-road fuel usage with undeniable results. Such a survey, designed with the specific purpose of determining off-road fuel use, has not been conducted as of this time.

On the basis of using valid and consistent data that obviously relates to off-road vehicles, ORNL determined that the only new data set that is reasonable in terms of this analysis is that of rural net land area, as provided in Highway Statistics 1997. A methodology for using this data is explained in the following chapter. 


\section{SUMMARY AND CONCLUSIONS}

Since 1994, FHWA has been using a modification of the model developed by ORNL to estimate the fuel used for off-road recreation in order to apportion funds to each State under the Recreational Trails Program. To ensure that the method for distributing program funds benefits from recent, more accurate data than those available in 1993-1994, this effort re-evaluated the methodology. As in the previous study (ORNL, 1994), it was determined that a standardized estimation procedure for all States using easily obtainable and understandable data would be preferred over State-submitted reports. Reasons for this rationale include incompatibility of Statesubmitted estimates, along with the fact that an estimation procedure would still be required at the Federal level for States which did not submit estimates. For this reason, individual State surveys were not heavily investigated during this effort.

In this report ORNL has examined off-road recreational fuel use by four vehicle types - light trucks, motorcycles, ATVs, and snowmobiles. Fuel use estimates rely on the population of vehicles within a State and an estimate of the average annual fuel used per vehicle. The amount of time a vehicle is used for recreational pursuits as opposed to non-recreational off-road travel was also taken into consideration, as well as opportunity for recreational use (e.g., snowfall). A summary of fuel use for all vehicle types by State is provided in Table 7.1.

The FHWA had concerns that light truck fuel use was overestimated in their previous off-road fuel use estimates. Table 7.1 shows that, when the updated data and revised methodologies are incorporated, light trucks represent approximately $79 \%$ of the total off-road fuel use. The most recent FHWA estimations prior to this study estimated that off-road fuel consumption by light trucks represented $90 \%$ of the total off-road fuel usage. 
Table 7.1. Off-road fuel use estimates by vehicle type, $1997^{1}$ (gallons)

\begin{tabular}{|c|c|c|c|c|c|c|}
\hline State & Light trucks & Motorcycles & ATVs & Snowmobiles & Total & Percentage \\
\hline Alabama & $30,856,673$ & $2,265,600$ & $3,901,846$ & $\overline{0}$ & $37,024,120$ & $2.010 \%$ \\
\hline Alaska & $5,212,941$ & 542,800 & $1,530,085$ & $7,559,082$ & $14,844,908$ & $0.806 \%$ \\
\hline Arizona & $28,791,650$ & $2,295,100$ & $1,986,104$ & 157,481 & $33,230,335$ & $1.804 \%$ \\
\hline Arkansas & $26,101,369$ & $1,345,200$ & $4,250,093$ & 0 & $31,696,662$ & $1.721 \%$ \\
\hline California & $151,880,913$ & $21,098,400$ & $7,630,762$ & 446,458 & $181,056,533$ & $9.828 \%$ \\
\hline Colorado & $35,484,731$ & $3,068,000$ & $1,421,229$ & $1,851,975$ & $41,825,936$ & $2.270 \%$ \\
\hline Connecticut & $7,711,202$ & $1,711,000$ & 587,234 & 86,977 & $10,096,413$ & $0.548 \%$ \\
\hline Delaware & $3,123,599$ & 318,600 & 214,801 & 8,962 & $3,665,962$ & $0.199 \%$ \\
\hline District of Columbia & 451,235 & 59,000 & 1,889 & 0 & 512,125 & $0.028 \%$ \\
\hline Florida & $59,862,296$ & $6,106,500$ & $3,485,716$ & 0 & $69,454,512$ & $3.770 \%$ \\
\hline Georgia & $51,556,948$ & $4,183,100$ & $4,350,959$ & 0 & $60,091,007$ & $3.262 \%$ \\
\hline Hawaii & $4,088,072$ & 0 & 0 & 0 & $4,088,072$ & $0.222 \%$ \\
\hline Idaho & $20,409,470$ & $2,029,600$ & $1,451,672$ & $3,475,132$ & $27,365,874$ & $1.486 \%$ \\
\hline Illinois & $43,590,877$ & $4,041,500$ & $3,029,883$ & $2,882,930$ & $53,545,190$ & $2.907 \%$ \\
\hline Indiana & $24,797,028$ & $2,820,200$ & $2,672,346$ & 634,731 & $30,924,306$ & $1.679 \%$ \\
\hline Iowa & $20,067,856$ & $1,274,400$ & $1,448,079$ & $1,637,014$ & $24,427,349$ & $1.326 \%$ \\
\hline Kansas & $20,529,419$ & 979,400 & $1,074,934$ & 0 & $22,583,753$ & $1.226 \%$ \\
\hline Kentucky & $25,793,937$ & $1,888,000$ & $3,333,937$ & 0 & $31,015,874$ & $1.684 \%$ \\
\hline Louisiana & $42,637,561$ & $1,498,600$ & $4,163,875$ & 0 & $48,300,036$ & $2.622 \%$ \\
\hline Maine & $7,357,339$ & 767,000 & $1,111,756$ & $9,607,120$ & $18,843,216$ & $1.023 \%$ \\
\hline Maryland & $14,531,934$ & $2,265,600$ & $1,016,372$ & 7,772 & $17,821,678$ & $0.967 \%$ \\
\hline Massachusetts & $17,172,042$ & $2,749,400$ & 915,877 & 877,770 & $21,715,090$ & $1.179 \%$ \\
\hline Michigan & $37,695,980$ & $5,315,900$ & $5,650,449$ & $24,175,467$ & $72,837,796$ & $3.954 \%$ \\
\hline Minnesota & $23,323,683$ & $2,212,500$ & $3,298,168$ & $22,729,108$ & $51,563,458$ & $2.799 \%$ \\
\hline Mississippi & $42,009,091$ & 867,300 & $3,456,047$ & 0 & $46,332,439$ & $2.515 \%$ \\
\hline Missouri & $39,828,793$ & $2,112,200$ & $3,615,755$ & 0 & $45,556,747$ & $2.473 \%$ \\
\hline Montana & $16,392,660$ & $1,085,600$ & $1,058,799$ & $1,662,263$ & $20,199,323$ & $1.096 \%$ \\
\hline Nebraska & $9,050,538$ & 595,900 & $1,132,258$ & 91,408 & $10,870,103$ & $0.590 \%$ \\
\hline Nevada & $9,100,192$ & $1,386,500$ & 688,936 & 0 & $11,175,628$ & $0.607 \%$ \\
\hline New Hampshire & $3,589,391$ & $1,044,300$ & 705,009 & $4,083,952$ & $9,422,653$ & $0.511 \%$ \\
\hline New Jersey & $34,101,851$ & $3,569,500$ & $1,439,408$ & 83,107 & $39,193,867$ & $2.128 \%$ \\
\hline New Mexico & $26,200,256$ & $1,209,500$ & 810,923 & 41,206 & $28,261,886$ & $1.534 \%$ \\
\hline New York & $42,472,485$ & $5,593,200$ & $4,411,875$ & $12,732,328$ & $65,209,888$ & $3.540 \%$ \\
\hline North Carolina & $41,113,992$ & $4,454,500$ & $4,034,270$ & 0 & $49,602,762$ & $2.693 \%$ \\
\hline North Dakota & $6,021,267$ & 330,400 & 528,981 & $1,339,457$ & $8,220,106$ & $0.446 \%$ \\
\hline Ohio & $51,408,831$ & $5,445,700$ & $4,449,688$ & $1,140,949$ & $62,445,167$ & $3.390 \%$ \\
\hline Oklahoma & $32,166,929$ & $1,799,500$ & $1,838,506$ & 0 & $35,804,934$ & $1.944 \%$ \\
\hline Oregon & $27,910,158$ & $2,832,000$ & $2,106,697$ & $1,332,033$ & $34,180,888$ & $1.855 \%$ \\
\hline Pennsylvania & $32,367,925$ & $5,911,800$ & $5,335,866$ & $2,844,104$ & $46,459,695$ & $2.522 \%$ \\
\hline Rhode Island & $3,224,605$ & 436,600 & 92,102 & 5,754 & $3,759,061$ & $0.204 \%$ \\
\hline South Carolina & $22,318,066$ & $1,958,800$ & $1,659,784$ & 0 & $25,936,650$ & $1.408 \%$ \\
\hline South Dakota & $5,586,413$ & 418,900 & 616,995 & $1,036,445$ & $7,658,753$ & $0.416 \%$ \\
\hline Tennessee & $33,934,051$ & $2,796,600$ & $4,238,448$ & 0 & $40,969,099$ & $2.224 \%$ \\
\hline Texas & $116,695,478$ & $7,911,900$ & $6,683,482$ & 0 & $131,290,860$ & $7.127 \%$ \\
\hline$\overline{\text { Utah }}$ & $13,934,165$ & $1,893,900$ & $2,296,506$ & $2,430,519$ & $20,555,090$ & $1.116 \%$ \\
\hline Vermont & $3,203,522$ & 348,100 & $459,4.56$ & $3,094,650$ & $7,105,728$ & $0.386 \%$ \\
\hline Virginia & $47,809,066$ & $3,115,200$ & $2,234,166$ & 0 & $53,158,432$ & $2.886 \%$ \\
\hline Washington & $40,226,989$ & $4,607,900$ & $1,891,834$ & $2,761,394$ & $49,488,117$ & $2.686 \%$ \\
\hline West Virginia & $13,347,241$ & $1,445,500$ & $2,786,560$ & 0 & $17,579,300$ & $0.954 \%$ \\
\hline Wisconsin & $22,672,433$ & $2,271,500$ & $3,293,212$ & $16,718,704$ & $44,955,850$ & $2.440 \%$ \\
\hline Wyoming & $14,805,589$ & 572,300 & 695,161 & $2,195,053$ & $18,268,103$ & $0.992 \%$ \\
\hline Total & $1,454,520,733$ & $136,850,500$ & $121,088,790$ & $129,731,307$ & $1,842,191,331$ & \\
\hline Percentage by type & $79.0 \%$ & $7.4 \%$ & $6.6 \%$ & $7.0 \%$ & $100.0 \%$ & \\
\hline
\end{tabular}

${ }^{1}$ Snowmobile population data as of 1998. 
Vehicle registration data can be misleading for estimating fuel use by State if a vehicle travels in a different State than that in which it is registered. This is the case with the small amounts of fuel use shown in the District of Columbia (Table 7.1), because there are no areas available for off-road recreation within the District (FHWA, Recreational Trails Program Office, personal communication with S. C. Davis, ORNL, October 13, 1998). Since the fuel use estimations recommended in this report rely heavily on vehicle registrations, ORNL investigated other factors which might impact the amount of fuel used for off-road recreation and could be used in conjunction with fuel use to derive the most equitable apportionment of funds. It was concluded in Chapter 6 that the acreage of net rural lands is a valid measure that relates to off-road recreational vehicle use.

Although the availability of rural land is a proxy for an opportunity to participate in off-road recreational activities, it is not apparent that there is a direct correlation between the number of square miles of land and the numbers of gallons of fuel consumed. ORNL examined the possibility of classifying the States into broad categories on the basis of how much rural land is available (Table 7.2). These categories are defined as follows. Category 1 includes 10 States (including the District of Columbia) that have either very little or no rural land, which implies that there is limited opportunity for off-road recreation. Category 2, with eight States, includes all States with rural lands of 20-40,000 square miles available for offhighway riding. Category 3 includes 13 States with 40-60,000 rural square miles. Category 4 includes seven States, all of which have 60-80,000 square miles of rural land. Category 5 includes five States, all of which have 80-100,000 square miles of rural land. Categories 6 and 7 contain three and five States, respectively, with $100-120,000$ square miles and over 120,000 square miles of land classified as rural.

If a State is in category 1, with little or no Federal land available, the estimation of fuel usage for that State remains constant (i.e., unchanged from the totals given in Table 7.1). If a State is in category 2 (a greater opportunity to ride off-road because 
Table 7.2. Categories of rural land availability for off-road recreation (square miles of net rural land)

\begin{tabular}{lllllll}
\hline Category 1: & Category 2: & Category 3: & Category 4: & Category 5: & Category 6: & Category 7: \\
$<20,000$ & $20-40,000$ & $40-60,000$ & $60-80,000$ & $80-100,000$ & $100-120,000$ & $>120,000$ \\
\hline Connecticut & Indiana & Alabama & Minnesota & Idaho & Arizona & Alaska \\
Delaware & Kentucky & Arkansas & Missouri & Kansas & Colorado & California \\
DC & Maine & Florida & Nebraska & Oregon & Nevada & Montana \\
Hawaii & Ohio & Georgia & N. Dakota & Utah & & New Mexico \\
Maryland & S. Carolina & Illinois & Oklahoma & Wyoming & & Texas \\
Massachusetts & Tennessee & Iowa & S. Dakota & & & \\
New Hampshire & Virginia & Louisiana & Washington & & & \\
New Jersey & W. Virginia & Michigan & & & & \\
Rhode Island &. & Mississippi & & & & \\
Vermont & & N. Carolina & & & \\
& & New York & & & \\
& Pennsylvania & & & \\
& Wisconsin & & & \\
\end{tabular}

Based on data from Table 6.2.

of the greater amount of rural land available), that State will receive a bonus of 5\%; if in category 3 , the State will receive a bonus of $10 \%$; if in category 4 , the State will receive a bonus of $15 \%$; if in category 5 , the State will receive a bonus of $20 \%$; States in categories 6 and 7 receive bonuses of $25 \%$ and 30\%, respectively. This methodology is similar to that described in Chapter 5, when applying the adjustment factor for average annual snow fall and normal winter temperature. After applying this adjustment factor to the total off-road recreational fuel use, the final apportionment of State funding is shown on Table 7.3.

Table 7.3 provides the percentages of off-road fuel use, by State, at this time (March 1999). The most recent data available (1997 for light trucks, motorcycles, and ATVs; 1998 for snowmobiles) have been used for these calculations. 
Table 7.3. Final allocation using rural land factor adjustment

\begin{tabular}{|c|c|c|c|}
\hline State & $\begin{array}{c}\text { Total off-road } \\
\text { recreational fuel use } \\
\text { (gallons) }\end{array}$ & $\begin{array}{l}\text { Rural land } \\
\text { factor } \\
\text { adjustment } \\
\end{array}$ & $\begin{array}{l}\text { Final allocation } \\
\text { (percentage) }\end{array}$ \\
\hline Alabama & $37,024,120$ & $10 \%$ & $1.929 \%$ \\
\hline Alaska & $14,844,908$ & $30 \%$ & $0.914 \%$ \\
\hline Arizona & $33,230,335$ & $25 \%$ & $1.967 \%$ \\
\hline Arkansas & $31,696,662$ & $10 \%$ & $1.651 \%$ \\
\hline California & $181,056,533$ & $30 \%$ & $11.147 \%$ \\
\hline Colorado & $41,825,936$ & $25 \%$ & $2.476 \%$ \\
\hline Connecticut & $10,096,413$ & $0 \%$ & $0.478 \%$ \\
\hline Delaware & $3,665,962$ & $0 \%$ & $0.174 \%$ \\
\hline District of Columbia & 512,125 & $0 \%$ & $0.024 \%$ \\
\hline Florida & $69,454,512$ & $10 \%$ & $3.618 \%$ \\
\hline Georgia & $60,091,007$ & $10 \%$ & $3.131 \%$ \\
\hline Hawaii & $4,088,072$ & $0 \%$ & $0.194 \%$ \\
\hline Idaho & $27,365,874$ & $20 \%$ & $1.555 \%$ \\
\hline Illinois & $53,545,190$ & $10 \%$ & $2.790 \%$ \\
\hline Indiana & $30,924,306$ & $5 \%$ & $1.538 \%$ \\
\hline Iowa & $24,427,349$ & $10 \%$ & $1.273 \%$ \\
\hline Kansas & $22,583,753$ & $20 \%$ & $1.284 \%$ \\
\hline Kentucky & $31,015,874$ & $5 \%$ & $1.542 \%$ \\
\hline Louisiana & $48,300,036$ & $10 \%$ & $2.516 \%$ \\
\hline Maine & $18,843,216$ & $5 \%$ & $0.937 \%$ \\
\hline Maryland & $17,821,678$ & $0 \%$ & $0.844 \%$ \\
\hline Massachusetts & $21,715,090$ & $0 \%$ & $1.028 \%$ \\
\hline Michigan & $72,837,796$ & $10 \%$ & $3.795 \%$ \\
\hline Minnesota & $51,563,458$ & $15 \%$ & $2.808 \%$ \\
\hline Mississippi & $46,332,439$ & $10 \%$ & $2.414 \%$ \\
\hline Missouri & $45,556,747$ & $15 \%$ & $2.481 \%$ \\
\hline Montana & $20,199,323$ & $30 \%$ & $1.244 \%$ \\
\hline Nebraska & $10,870,103$ & $15 \%$ & $0.592 \%$ \\
\hline Nevada & $11,175,628$ & $25 \%$ & $0.662 \%$ \\
\hline New Hampshire & $9,422,653$ & $0 \%$ & $0.446 \%$ \\
\hline New Jersey & $39,193,867$ & $0 \%$ & $1.856 \%$ \\
\hline New Mexico & $28,261,886$ & $30 \%$ & $1.740 \%$ \\
\hline New York & $65,209,888$ & $10 \%$ & $3.397 \%$ \\
\hline North Carolina & $49,602,762$ & $10 \%$ & $2.584 \%$ \\
\hline North Dakota & $8,220,106$ & $15 \%$ & $0.448 \%$ \\
\hline Ohio & $62,445,167$ & $5 \%$ & $3.105 \%$ \\
\hline Oklahoma & $35,804,934$ & $15 \%$ & $1.950 \%$ \\
\hline Oregon & $34,180,888$ & $20 \%$ & $1.943 \%$ \\
\hline Pennsylvania & $46,459,695$ & $10 \%$ & $2.420 \%$ \\
\hline Rhode Island & $3,759,061$ & $0 \%$ & $0.178 \%$ \\
\hline South Carolina & $25,936,650$ & $5 \%$ & $1.290 \%$ \\
\hline South Dakota & $7,658,753$ & $15 \%$ & $0.417 \%$ \\
\hline Tennessee & $40,969,099$ & $5 \%$ & $2.037 \%$ \\
\hline Texas & $131,290,860$ & $30 \%$ & $8.083 \%$ \\
\hline Utah & $20,555,090$ & $20 \%$ & $1.168 \%$ \\
\hline Vermont & $7,105,728$ & $0 \%$ & $0.337 \%$ \\
\hline Virginia & $53,158,432$ & $5 \%$ & $2.644 \%$ \\
\hline Washington & $49,488,117$ & $15 \%$ & $2.695 \%$ \\
\hline West Virginia & $17,579,300$ & $5 \%$ & $0.874 \%$ \\
\hline Wisconsin & $44,955,850$ & $10 \%$ & $2.342 \%$ \\
\hline Wyoming & $18,268,103$ & $20 \%$ & $1.038 \%$ \\
\hline Total & $1,842,191,331$ & & $100.000 \%$ \\
\hline
\end{tabular}

Based on Tables 7.1 and 7.2. 
In order to get the most accurate estimates from the model, it is important to update the input data as often as new data become available. Below is a summary of the ORNL recommendations for these updates.

- Light trucks: (1) update the number of FVE trucks annually, using Table MV-9 from Highway Statistics, 2 update annual miles and fuel economy annually, using Table VM-1 from Highway Statistics, 3 update the percentages of trucks used for off-road recreation every five years, using TIUS data and the programs provided in Appendix B, and 4 use TIUS data and the programs provided in Appendix B to determine the off-road fuel economy and annual miles discounts;

- Motorcycles: update the number of motorcycles ridden off-road each year, using the data supplied by the MIC in the Statistical Annual;

- ATVs: contact the MIC annually to determine whether an update has been calculated;

- Snowmobiles: update the number of registered snowmobiles annually (in late Spring), based on registration material supplied by the ACSA; for States that require registrations but do not report snowmobile populations to ACSA, contact the responsible State agency for updated numbers;

- Rural land: update the square miles of rural land each year using the Highway Statistics Table PS-1.

Outdoor recreational activities are becoming more and more popular every year. Participants, including men, women, and children, are active in maintaining trails and protecting the environment. In this report, we show that the enthusiasm for off-road vehicle recreation requires a substantial quantity of fuel each year - almost 2 billion gallons, based on currently available data! This fuel usage represents a $27 \%$ increase over the 1992 estimated fuel use. Although there are differences among the off-road vehicles considered in this study (e.g., the snowmobile riding season is not equal to 
the motorcycle riding season), every single vehicle type saw an increase in the total amount of annual fuel use.

Recognizing the importance of recreational trail funds to the States, ORNL examined various information sources and analyzed the available data. ORNL then calculated a fair and equitable distribution that is based on the vehicles within each State, the fuel economy of each type of vehicle, and the opportunity for usage within each State. This formula for apportionment, in spreadsheet format, was provided to FHWA. 


\section{REFERENCES}

BLM, March 1998, Public Lands Statistics 1997 - Volume 182, BLM/BC/ST-98/001+1165, Table 1-4 and Table 5-10, http://www.blm.gov/natacq/pls97.

Bureau of the Census, 1990, 1987 Truck Inventory and Use Survey Microdata File, Washington, DC.

Bureau of the Census, June 1995, 1992 Truck Inventory and Use Survey Microdata File, Washington, DC.

Bureau of the Census, 1992, "1992 Census of Transportation, 1992 Truck Inventory and Use Survey," Form TC-9501, Washington, DC.

Bureau of the Census, 1997, Statistical Abstract of the United States 1997, Washington, DC.

CPSC, April 1998, Part I, Report on 1997 ATV Exposure Survey, Bethesda, MD.

EPA, March/April 1995, "Nonpoint Source News-Notes," Issue \#40, http://www.epa.gov/owowwtr1/info/NewsNotes/issue40/nps40nat.html.

FHWA, November 1998, Highway Statistics 1997, Washington, DC.

FHWA, October 1995, Highway Statistics 1994, Washington, DC.

FHWA, 1967, Highway Statistics 1966, Washington, DC.

ISMA, 1998, "Snowmobiling Fact Book," Snow Facts, http://www.snowmobile.org/t_snfcts.htm, Hasslett, $\mathrm{MI}$.

MIC, 1998, 1998 Motorcycle Statistical Annual, Irvine, CA.

MIC, 1997, 1997 Motorcycle Statistical Annual, Irvine, CA.

MIC, 1995, 1995 Motorcycle Statistical Annual, Irvine, CA.

MIC, 1994, 1994 Motorcycle Statistical Annual, Irvine, CA.

MIC, 1993, 1993 Motorcycle Statistical Annual, Irvine, CA.

MIC, 1992, 1992 Motorcycle Statistical Annual, Irvine, CA.

MIC, 1991, 1991 Motorcycle Statistical Annual, Irvine, CA. 


\section{REFERENCES (Continued)}

NCDC, 1998, "Normal High and Low Temperatures" as published in the World Almanac and Book of Facts 1999, Mahwah, NJ, p. 221.

NFS, January 1998, "Land Areas of the National Forest System as of September 1997," Table 4 and Table 9, http://www.fs.fed.us/database/lar/97.

ORNL, July 1994. Fuel Used for Off-Highway Recreation, ORNL-6794, Oak Ridge, TN.

ORNL, March 1999, ORNL Light-Duty Vehicle MPG and Market Shares System Database of light-duty vehicle sales and characteristics], Oak Ridge, TN.

SVIA, September 1998, "State All-Terrain Vehicle Requirements," Irvine, CA. 


\section{Appendix A}

\section{Detailed Registration Information}

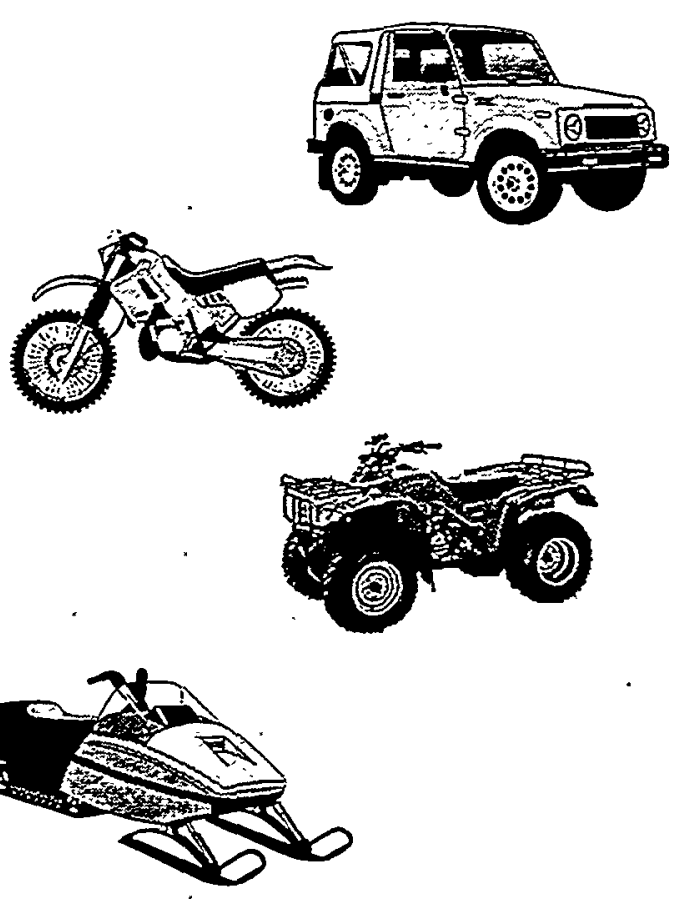




\section{A DETAILED REGISTRATION INFORMATION}

\section{A.1 Light Trucks}

All light trucks which travel on-road are required to be registered with the State Department of Motor Vehicles (DMV). Pickup trucks and sports utility vehicles which are specifically used for off-road recreation are almost always driven at some point on-road, and, therefore, would be registered with the State. Only vehicles which always recreate off-road in the same location as they are stored or vehicles which are always trailered to recreational locations could avoid State registration.

\section{A.2 Motorcycles}

Each year the Motorcycle Industry Council (MIC) collects information concerning the registration of off-road motorcycles and publishes it in the Motorcycle Statistical Annual. Since there is no Federal requirement for registering off-road motorcycles, the States set their own policies and have many different requirements concerning registration of these vehicles. Some States register off-road motorcycles with the motor vehicle registration agency and others register with the recreation management agency. Some States only register the vehicles if they use certain State lands. There are also exceptions for off-road motorcycles used in competitive events. Each State maintains its own records on off-road motorcycles according to its own registration conditions; thus, there is no central location of all off-road motorcycle registration data. The chart "State Off-Highway Motorcycle Requirements" (MIC, 1998) which lists the specific requirements for each State follows the text of Appendix A.

\section{A.3 All-Terrain Vehicles (ATVs)}

The Government Relations Office of the Specialty Vehicle Institute of America compiles data each year on State ATV registration requirements. Like off-road 
motorcycles, each State provides rules concerning ATV registration. ATVs may be required to register only if they travel on public lands; they may be required to register either through the motor vehicle registration agency or the recreation management agency; they may have registration exclusions for authorized events; and there is no central location of nationwide registration data. The chart "State AllTerrain Vehicle Requirements" (SVIA, 1998) which lists the specific registration requirements of each State is found at the end of Appendix A.

\section{A.4 Snowmobiles}

Snowmobile registration requirements are also not consistent across States. Nor is there a Federal requirement or central repository for registrations. The two snowmobile associations, the ISMA and the ACSA, both collect population numbers. Neither organization collects registration information from the States which have registration requirements but very small numbers of snowmobiles. In addition, the numbers of snowmobiles reported by the two organizations are not consistent. The inconsistency is easily explained. Since there is no central data repository, data collection is by phone calls to the State DMVs. Because the States have different requirements for the length of time that a registration is valid, the two organizations may collect the number of registered snowmobiles at different times in the registration cycle. Other problems with collecting the numbers of snowmobiles include the number of vehicles that are not registered, the fact that Alaska (which has a large snowmobile population) has only recently required registration, the problem with combining snowmobiles with other off-road vehicles in a common registration category, and the fact that Arizona has a large snowmobile population and does not require registration. 


\section{August, 1998}

\begin{tabular}{|c|c|c|c|c|c|c|c|c|c|c|c|}
\hline State & 0 & 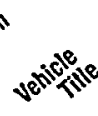 & 08 & 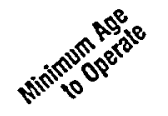 & is & $s^{e^{5}}$ & 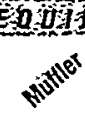 & 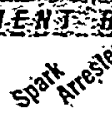 & 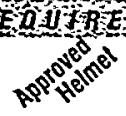 & $a^{20}$ & $80^{40}+200^{300}$ \\
\hline $\begin{array}{l}\text { Alabama } \\
\text { Alaska } \\
\text { Arizona } \\
\end{array}$ & & - & & 14BH & & & -f $f$ & & & & $x$ \\
\hline $\begin{array}{l}\text { Arkansas } \\
\text { Califomia } \\
\text { Colorado }\end{array}$ & $\begin{array}{l}\because \mathrm{Ad} \\
\therefore \text { Se } \\
\end{array}$ & - & & & $\begin{array}{l}-k \\
-k U \\
\end{array}$ & 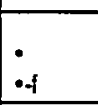 & $\begin{array}{l}-\mathrm{P}^{\mathrm{Mi}} \\
-\mathrm{A}\end{array}$ & $\begin{array}{l}-N \\
-f \\
-f\end{array}$ & & - & $x$ \\
\hline $\begin{array}{l}\text { Connecticut } \\
\text { Delaware } \\
\text { Dist. of Columbia }\end{array}$ & $\begin{array}{l}-E d \\
-E D d\end{array}$ & . & $\div$ & $12 B$ & $\cdot-k$ & $\because$ & $\cdot-\mathrm{NAf}$ & . & - & & $x$ \\
\hline $\begin{array}{l}\text { Florida } \\
\text { Georgia } \\
\text { Hawail }\end{array}$ & oEet & & & & & - & - & & & & \\
\hline $\begin{array}{l}\text { diaho } \\
\text { Illinois } \\
\text { Indiana }\end{array}$ & $\begin{array}{l}\cdot \cdot e \\
. . \text { UDe }\end{array}$ & $\begin{array}{l}-.1 \\
.-1\end{array}$ & & $14 \mathrm{~B}$ & $\cdot-K$ & $-L$ & $\cdot-M$ & $-N$ & & & $x$ \\
\hline $\begin{array}{l}\begin{array}{l}\text { lowa } \\
\text { Kansas } \\
\text { Kentucky }\end{array} \\
\end{array}$ & $.0 \mathrm{ce}$ & & & $\begin{array}{l}12 \mathrm{UR}, 18 \mathrm{Ua} \\
\text { 12j, 16k\&B }\end{array}$ & $\cdot-k$ & $\bullet$ & $\begin{array}{l}\cdot-\mathrm{M} \\
.\end{array}$ & & - & & $-a$ \\
\hline $\begin{array}{l}\text { Louisiana } \\
\text { Maine } \\
\text { Maryland }\end{array}$ & $\begin{array}{l}\because \because \mathrm{d} \\
\because \mathrm{Fe} \\
\cdot \mathrm{eH}\end{array}$ & $\bullet$ & $\cdot-8 H$ & $\begin{array}{l}10,16 \mathrm{~B} \\
12 \mathrm{H}\end{array}$ & ${ }_{-1}^{-f} \mathrm{KH}$ & $\cdot H$ & $\begin{array}{l}-A M H \\
-A M H\end{array}$ & - & $-c$ & & $\cdot c$ \\
\hline $\begin{array}{l}\text { Massactiusetts } \\
\text { Michigan } \\
\text { Minnesota }\end{array}$ & $\begin{array}{l}-\because E \mathrm{Ee} \\
\because \mathrm{e} \\
\cdot \mathrm{UFd}\end{array}$ & .1 & & $\begin{array}{l}12,14 \mathrm{~B}, 10 \mathrm{~g} \\
16 \mathrm{~B} \& \mathrm{a} \\
16 \mathrm{aUh}, 12 \mathrm{BU}\end{array}$ & $\because-\mathrm{K}$ & $\because \mathrm{L}$ & ${ }_{-M A}^{-M A}$ & : & $\therefore$ & $\begin{array}{l}. p \\
. p\end{array}$ & -O \\
\hline $\begin{array}{l}\text { Mississippi } \\
\text { Missouri } \\
\text { Montana }\end{array}$ & -8 & -1 & & & & & & & & & $x$ \\
\hline $\begin{array}{l}\text { Nebraska } \\
\text { Nevada } \\
\text { NewHampshire }\end{array}$ & - $\mathrm{Fe}$ & - -1 & -CBora & $18 B$, borJ & $--k$ & $-t$ & $\cdot-M$ & : & - C & $\cdot P C$ & -GBorb \\
\hline $\begin{array}{l}\text { NewJersey } \\
\text { NewMexico } \\
\text { NewYook }\end{array}$ & $\begin{array}{l}\text { - Ed } \\
\text { - Fd }\end{array}$ & - & & $16 \mathrm{~B}, 10 \mathrm{~W}$ & $\cdot-\mathrm{Kf}$ & - & - - MII & $-\mathrm{N}$ & . & & $\rightarrow c$ \\
\hline $\begin{array}{l}\text { North Carotina } \\
\text { NorthDakota } \\
\text { Ohio }\end{array}$ & - Ed & & . U & $16 \mathrm{~B}, 12 \mathrm{~V}$ & - & - & $\cdot \mathrm{ANH}$ & & & & \\
\hline $\begin{array}{l}\text { Oklahomama } \\
\text { Oregon } \\
\text { Pennsyvania }\end{array}$ & $\cdot H d$ & & $\cdot-$ U, aorh & $7 U, 12 \cup B \& a$ & $\begin{array}{l}\cdot-\mathrm{KH} \\
-\mathrm{K}\end{array}$ & - & $\begin{array}{l}\cdot-H \\
\cdot-M \\
-H\end{array}$ & $\begin{array}{l}+H \\
-H \\
-H H\end{array}$ & $\begin{array}{ll}-H \\
-C\end{array}$ & & $\cdot-i$ \\
\hline $\begin{array}{l}\text { Rhodelstiand } \\
\text { South Carolina } \\
\text { SouthDakota }\end{array}$ & - Ee & $\dot{0-1}$ & & $12,16 \mathrm{BH}$ & $\cdot-\mathrm{k}$ & $\bullet$ & $\begin{array}{l}--\sqrt{11} \\
.\end{array}$ & & & $-a$ & \\
\hline $\begin{array}{l}\text { Tennessee } \\
\text { Texas } \\
\text { Utah }\end{array}$ & . UEd & $\dot{0}$ & $\cdot-a$ & $8 U, 16 a$ & $-k$ & - & $\begin{array}{l}\cdot H \\
\cdot * H\end{array}$ & \begin{tabular}{|l|}
$-{ }_{-H}$ \\
$--N H$
\end{tabular} & $\begin{array}{l}-H \\
-H \\
-H\end{array}$ & $\cdot P H$ & -b \\
\hline $\begin{array}{l}\text { Vermont } \\
\text { Virginia } \\
\text { Washington } \\
\end{array}$ & $\begin{array}{l}- \text {-UEd } \\
- \text {-Dd }\end{array}$ & & & $12 B$ & $-k$ & - & $\begin{array}{l}\cdot-\mathrm{MA} \\
-\mathrm{M}\end{array}$ & - & & & $x$ \\
\hline $\begin{array}{l}\text { WestVirginia } \\
\text { Wisconsin } \\
\text { Wyoming }\end{array}$ & & & & - & & & & & & & \\
\hline
\end{tabular}

- Requirement in law

A. Excep! street-registered OHMs. Identification sticker required to transport competition OHM. B. Uniess supervised.

C. Under age 18.

D. Except street-registered OHMs or OHMs in races.

E. Except street-registered OHMS.

F. Except OHMs in races.

G. For ages 12-17.

H.Applies only on certain state lands.

I. Only if lien exists.

J. Unless at least age 12 \& have salety certificate.

K. Night operation only.

L Specific performance requirements.

M.Decibel sound limit specified

N.Approved by U.S. Forest Service.

0 .Under age 16 ,

P. Eye protection

0.16 sq. in. reflective material each side of $\mathrm{OHM}$ and approved helmel.
R. Unless taking a salety course.

S. Except OHMs used only for agriculture or in

authonzed events.

T. For transier of ownership.

U. On public lands.

V. On DNR lands if accompanied by parent.

W. With salety certificale.

X. Safety education \& info program available. Y. Helmet and eye protection if under 18

Z For 1988 model year of newer.

a. Unless in possession of safety certificate.

b. Unless operator's license possessed.

c. Ages 10-15 unless supervised.

d. By motor vehicle registretion agency.

e. By recreation managemenl agency.

i. Except in authorized competitive events.

g. In authorized events.

h. Uniess accompanied by person at least

18 who holds license or operator permit.

i. Ages 7-12.

j. For OHM's over $70 \mathrm{cc}$

k. For OHM's over 9OCC
OHM SOUND LFVE UMIS

CA Manufd before $197392 \mathrm{dBA}: 1973-197488 \mathrm{dBA}$ 1975-1985 86 dBA, atter $198582 \mathrm{dBA}$ or $101 \mathrm{dBA}$

CO Manuf'd 1971-1972 86 dBA; after 197284 dBA; different local limits also pemitted

DE Manuf'd 1978 and after 88 dBA or EPA limit.

IA $86 \mathrm{dBA}$

ID $92 \mathrm{dBA}$; Effective $7 / 9496 \mathrm{dBA}$ ( $+3 \mathrm{dBA}$ correction factor)

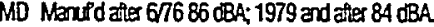

MA $103 \mathrm{dBA}$.

ME Must meet Federal EPA Standards.

Mi Model year 1983 and after - EPA limit; addritional limits specified in law.

NH Manuf'd 1973-74 88 dBA, 1975-1982 86 dBA. after 1982 EPA limit.

NY Must meel Federal EPA Standaris.

ND $85 \mathrm{dBA}$.

OR In use: model year 1975 and before $102 \mathrm{dBA}$, after $197599 \quad \mathrm{~d}, \mathrm{a}, \mathrm{d}$ ABA. Certifiction: $170 \mathrm{cc} \&$ under model year atter 1985 $80 \mathrm{dBA}$; over $170 \mathrm{cc}$ : model year after $198582 \mathrm{dBA}$ Racing: $105 \mathrm{dBA}$

Rl Manư'd after $5 / 7282 \mathrm{dBA}$; after $5 / 7473 \mathrm{dBA}$.

VT $82 \mathrm{dBA}$.

WA $86 \mathrm{dBA}$ or $105 \mathrm{dBA}$
TEST PROCEDURES

TEST PROCEDURE KEY 2- Acceleration test 50 leet incorporating SAE J331a or simizar test method.

b- Passby test 50 leet

c- Passby test 20 leet.

d- Stutionary test 20 inches.

$E-$ Measured at 50 feet Test procedure nol prescribed.

Athough the chart represents information irom the most authoritative sources avalizble as of the date showm above, dhe Motorgycie industry Councin is not responsidie for accuracy or completeness. Many of the provisions sum thanzed herein have excepions and may requir turher expladion. $t$ is necessay to rele to the actreal

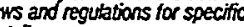


This chen is compiled by SVIA's Government Relotions Office. It will be updated onnually as state logislatures onact or amend ATV requirements. Please contact SVIA for edditional information concerning ATVS or for additional copios of this chart.

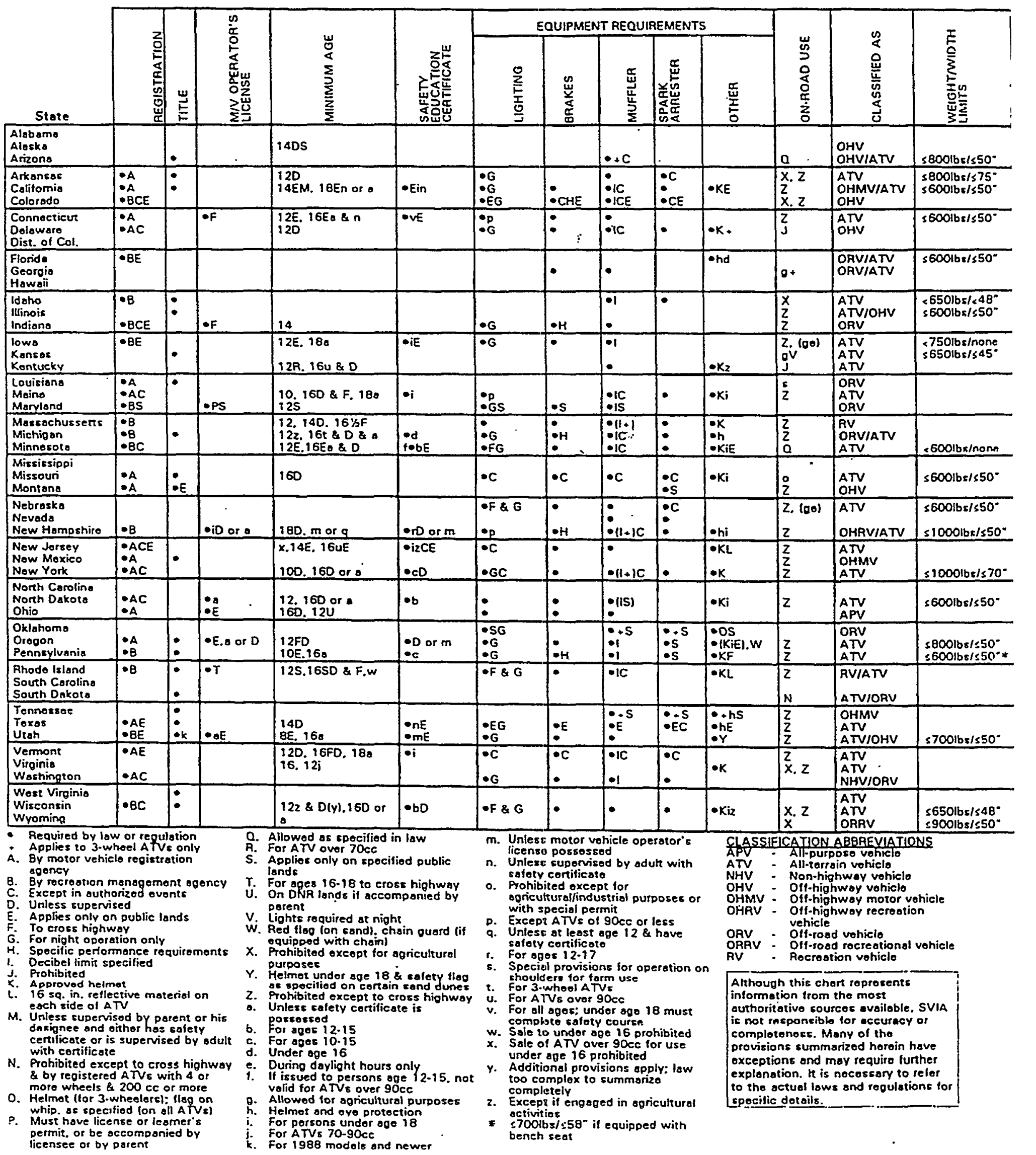




\section{Appendix B.}

\section{Truck Inventory and Use Survey Programs}

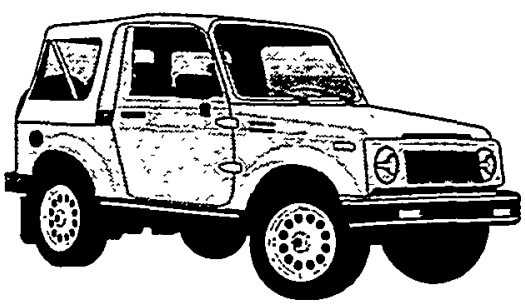


Program 1.

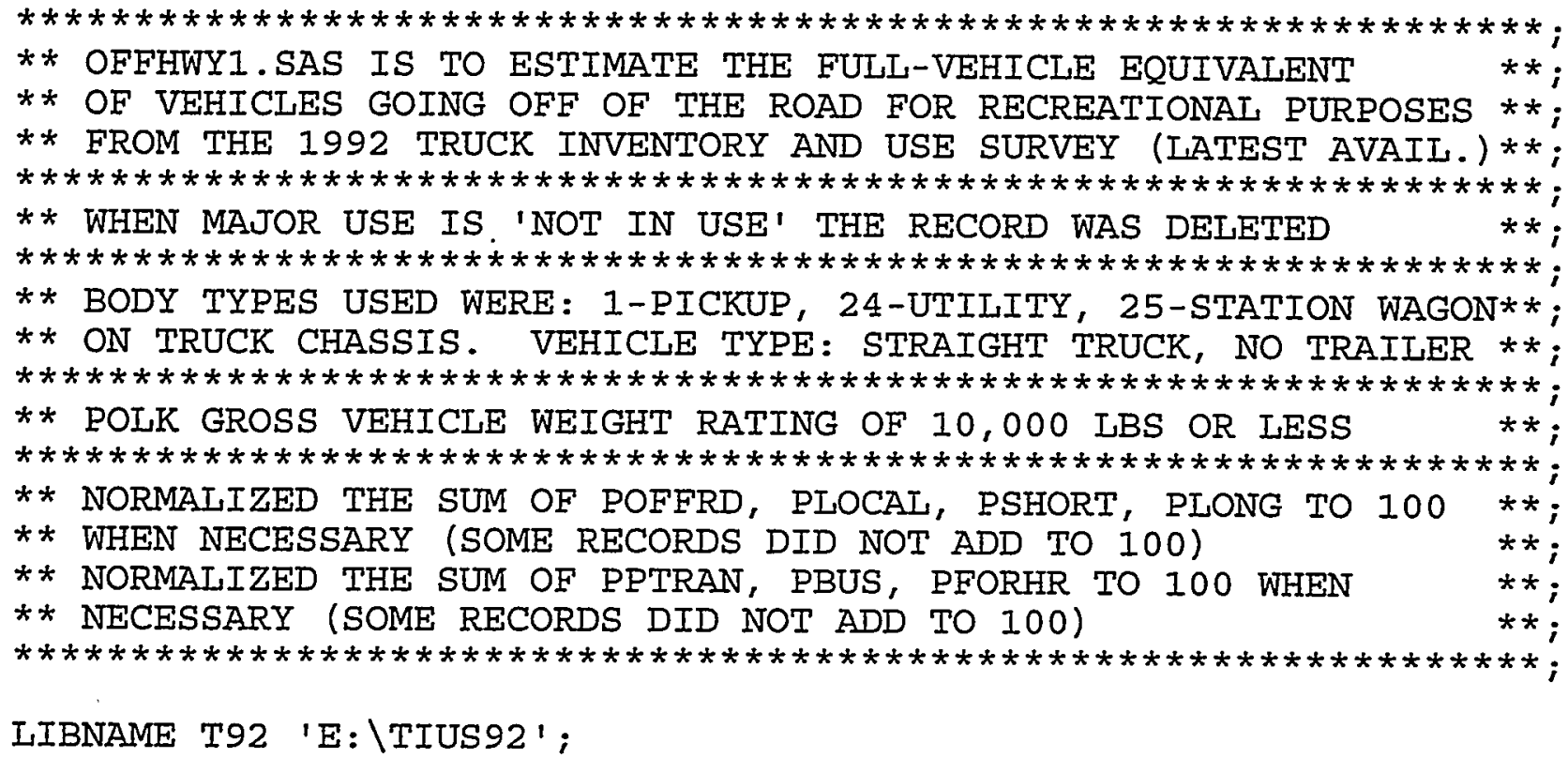

PROC FORMAT;

VALUE STATE

$1=$ 'AL'

$2=' A K '$

$4=$ 'AZ'

$5=$ 'AR'

$6=' \mathrm{CA}$ '

$8={ }^{\prime} \mathrm{CO}^{\prime}$

$9=$ 'CT'

$10=' \mathrm{DE}^{\prime}$

$11={ }^{\prime} \mathrm{DC}^{\prime}$

$12=$ ' $F I^{\prime}$ '

$13=$ 'GA'

$15=' \mathrm{HI}$ '

$16={ }^{\prime} I D^{\prime}$

$17={ }^{\prime} I I '$

$18={ }^{\prime} I^{\prime} N^{\prime}$

$19=$ 'IA'

$20=' \mathrm{KS}$ '

$2 I=' K Y$ '

$22={ }^{\prime}$ IA

$23=$ 'ME'

$24=$ 'MD'

$25=$ 'MA'

$26=$ 'MI'

$27={ }^{\prime M I N}$ '

$28=$ 'MS'

$29=' \mathrm{MO}$ '

$30=' M T '$ 


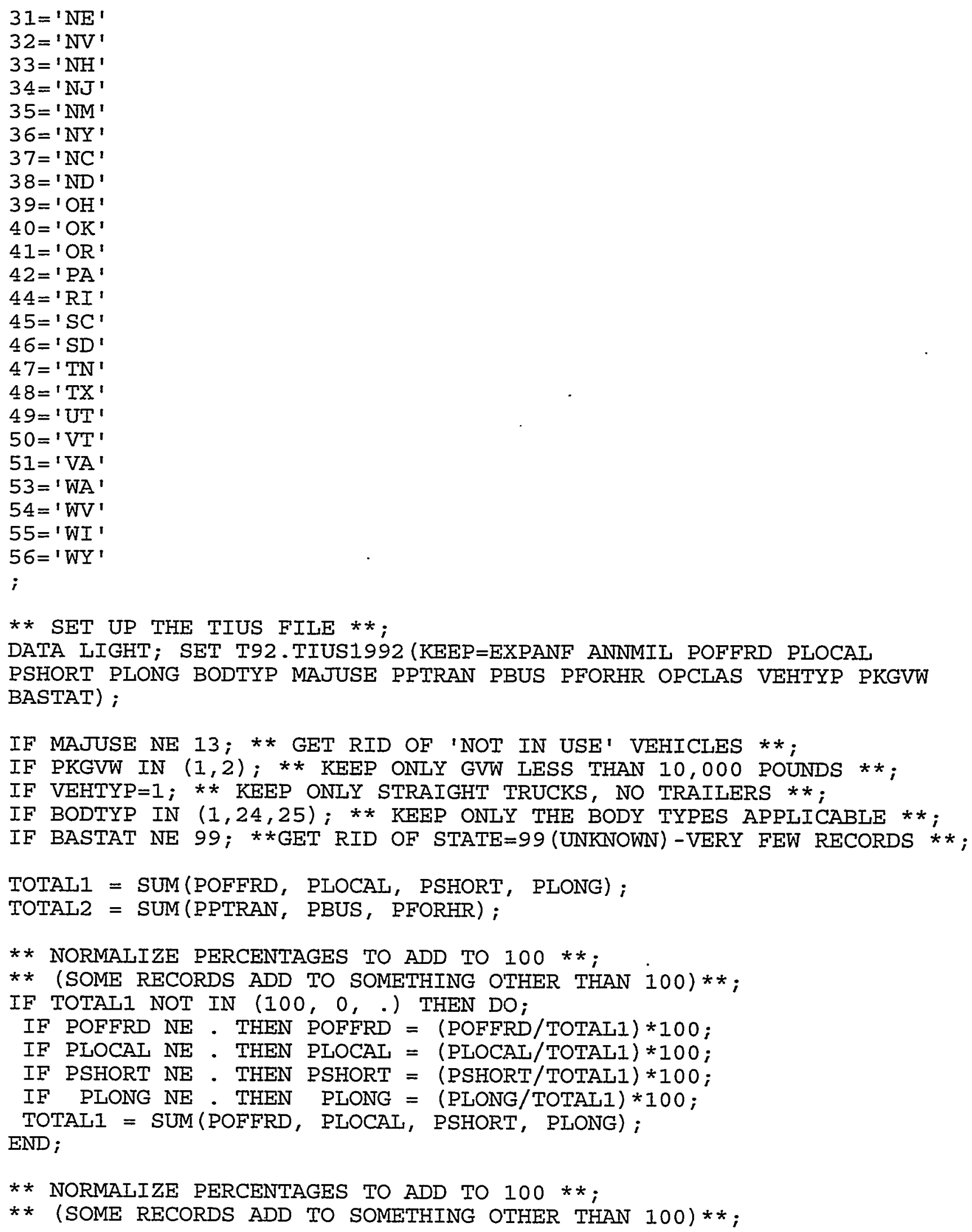


IF TOTAL2 NOT IN $(100,0,$.$) THEN DO;$

IF PPTRAN NE . THEN PPTRAN = (PPTRAN/TOTAI2)*100;

IF PBUS NE . THEN PBUS $=$ (PBUS/TOTAL2) $* 100$;

IF PFORHR NE. THEN PFORHR $=$ (PFORHR/TOTAL2)*100; END;

** CHANGE TO PROPER CODING ACCORDING TO THE CENSUS BUREAU DATA INPUT METHOD **;

IF OPCLAS $=2$ AND PPTRAN $=$. THEN PPTRAN $=100$;

ELSE IF OPCLAS IN $(1,3,4)$ AND PPTRAN=. THEN PPTRAN=0;

* * RECALCUI.ATE THE TOTAI **;

TOTAL2 = SUM (PPTRAN, PBUS, PFORHR);

* CHANGE TO PROPER CODING ACCORDING TO THE CENSUS BUREAU DATA INPUT METHOD **;

IF ROUND (TOTAII, I) $=100$ AND POFFRD $=$. THEN POFFRD $=0$;

** IF POFFRD, PLOCAL, PSHORT, AND PLONG ARE ALI MISSING **;

** THEN THE AVERAGE POFFRD BY STATE AND BODY TYPE ARE USED **;

DATA NONMISS MISS (DROP=POFFRD); SET LIGHT;

IF TOTALI IN $(\ldots, 0)$ THEN OUTPUT MISS;

ELSE OUTPUT NONMISS;

* * CREATE AVERAGE POFFRD BY BASE STATE AND BODY TYPE **;

PROC SUMMARY NWAY DATA=NONMISS;

CLASS BASTAT BODTYP;

VAR POFFRD;

WEIGHT EXPANF;

OUTPUT OUT $=S U M 1$ (DROP = TYPE_ _FREQ_ $) \quad M E A N=P O F F R D$;

PROC SORT DATA=MISS; BY BASTAT BODTYP;

** FILL IN MISSING DATA WITH THE AVERAGES JUST CREATED **;

DATA MISS2; MERGE MISS(IN=INI) SUMI; BY BASTAT BODTYP; IF IN1;

* *ET ALL THE DATA BACK TOGETHER AGAIN **;

DATA ALL; SET NONMISS MISS2;

* * SET UP THE PERCENTAGE OF RECREATIONAI OFF-ROADING * * ;

RECPCT $=($ POFFRD/100)*(PPTRAN/100);

FVETRKS $=$ EXPANF $*$ RECPCT;

* * COMBINE SPORTS UTILITY AND STATION WAGON ON TRUCK CHASSIS **;

* * TO MATCH HOW FHWA IIGHT TRUCK DATA ARE DISPLAYED **;

IF BODTYP=25 THEN BODTYP=24;

** SUM OVER STATE AND BODYTYPE FOR PICKUP TRUCKS **;

PROC SUMMARY NWAY DATA=AII;

WHERE BODTYP $=1$;

CLASS BASTAT;

VAR EXPANF FVETRKS;

OUTPUT OUT $=$ PUSET (DROP=_TYPE__FREQ_) SUM=PU OFFPU; 
* * SUM OVER STATE AND BODYTYPE FOR SPORT UTILITY TRUCKS **; PROC SUMMARY NWAY DATA=ALI;

WHERE BODTYP=24;

CLASS BASTAT;

VAR EXPANF FVETRKS;

OUTPUT OUT $=S U S E T$ (DROP $=$ TYPE_ _FREQ_) SUM=SU OFFSU;

DATA TRUCKSET; MERGE PUSET SUSET; BY BASTAT;

PCTPU =OFFPU/PU;

PCTSU=OFFSU/SU;

DATA NULL_ SET BYSTATE;

FILE 'C: \MYFILES \RV\SAS TIUSPCT.TXT';

PUT BASTAT STATE. ',' PCTPU ',' PCTSU;

RUN; 


\section{Program 2}
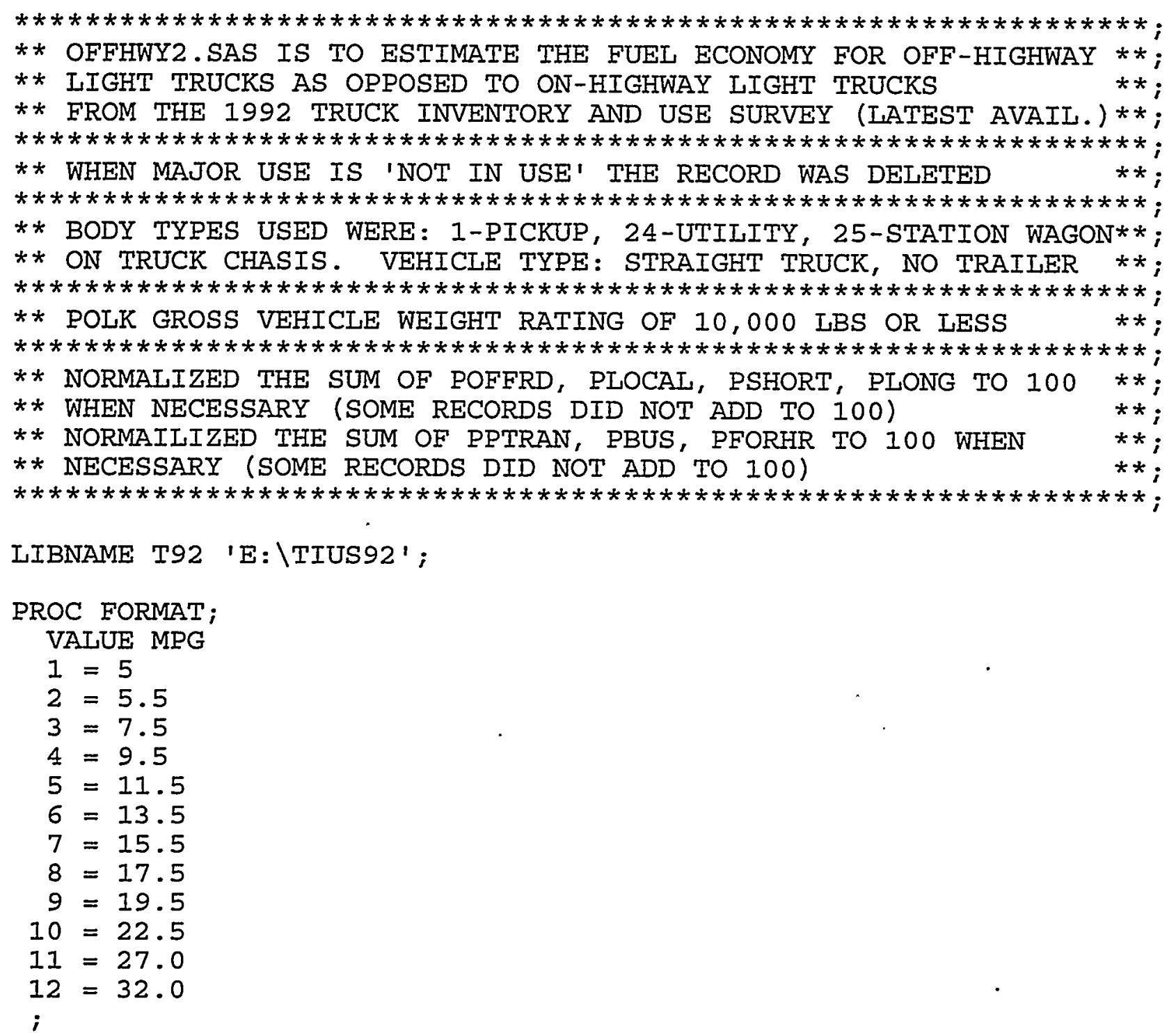

** SET UP THE TIUS FILE **; DATA LIGHT; SET T92.TIUS1992 (KEEP=EXPANF POFFRD PLOCAI PSHORT PLONG BODTYP MAJUSE

VEHTYP PKGVW MPGCK BASTAT ANNMIL);

IF MAJUSE NE 13; ** GET RID OF 'NOT IN USE' VEHICLES **;

IF PKGVW IN $(1,2) ; *$ KEEP ONLY GVW LESS THAN 10,000 POUNDS **;

IF VEHTYP $=1$; ** KEEP ONLY STRAIGHT TRUCKS, NO TRAILERS **;

IF BODTYP IN $(1,24,25)$; ** KEEP ONLY THE BODY TYPES APPIICABLE **; IF BASTAT NE 99; **GET RID OF STATE=99 (UNKNOWN) -VERY EEW RECORDS**; TOTALI = SUM (POFFRD, PLOCAL, PSHORT, PLONG); 


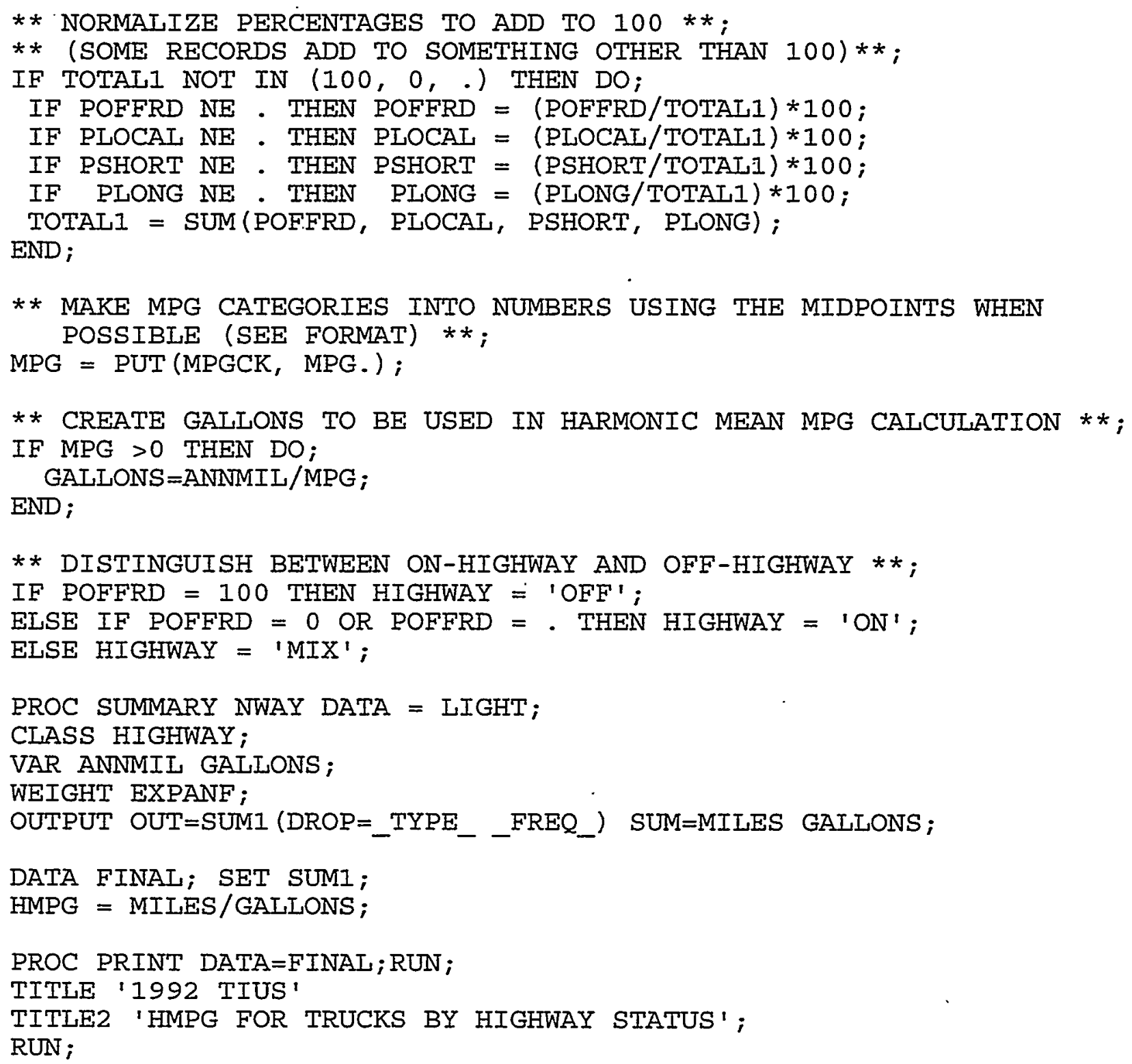




\section{Program 3}

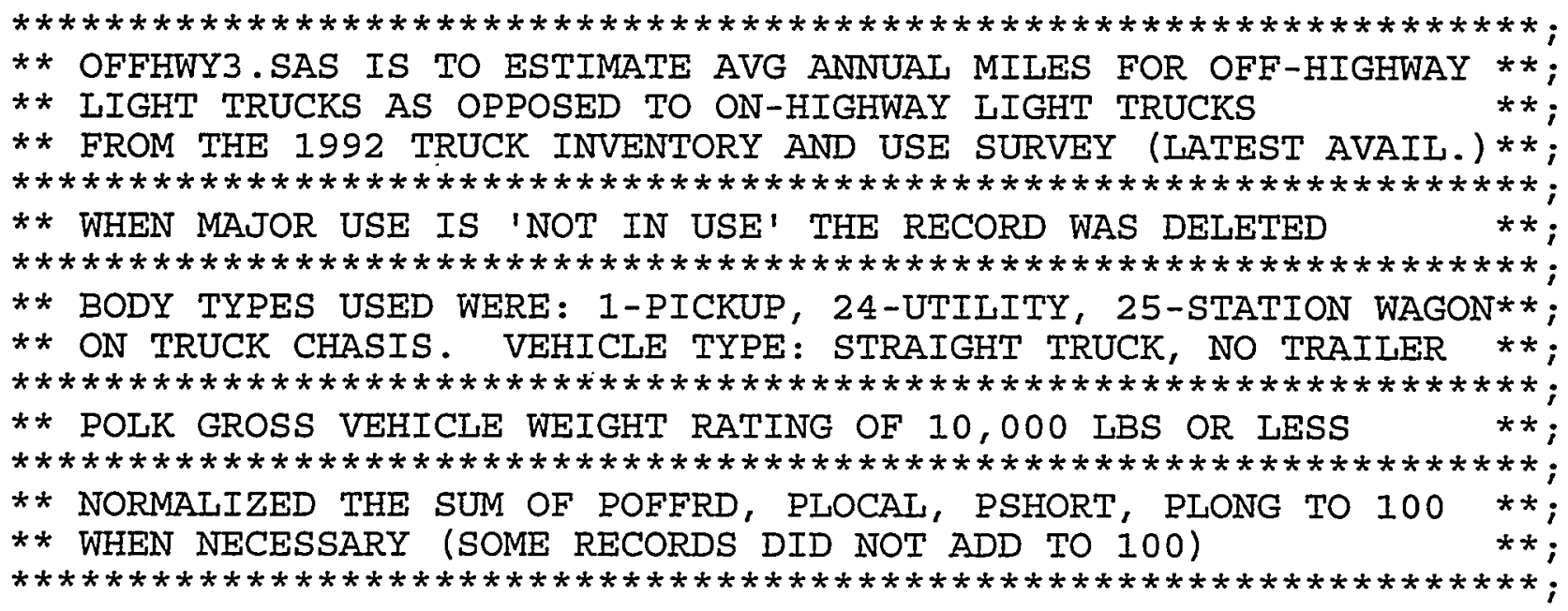

LIBNAME T92 'E:\TIUS92.';

** SET UP THE TIUS FILE **;

DATA LIGHT; SET T92.TIUS1992 (KEEP=EXPANF POFFRD PLOCAI PSHORT PLONG BODTYP MAJUSE

VEHTYP PKGVW MPGCK BASTAT ANNMIL);

IF MAJUSE NE 13; * * GET RID OF 'NOT IN USE' VEHICLES * *;

IF PKGVW IN $(1,2) ; *$ * KEEP ONLY GVW LESS THAN 10,000 POUNDS **;

IF VEHTYP $=1$; ** KEEP ONLY STRAIGHT TRUCKS, NO TRAILERS **;

IF BODTYP IN $(1,24,25) ; *$ K KEEP ONLY THE BODY TYPES APPLICABLE **;

IF BASTAT NE 99; ** GET RID OF STATE $=99$ (UNKNOWN) - VERY FEW

RECORDS **;

TOTALI = SUM (POFFRD, PLOCAL, PSHORT, PLONG);

** NORMAIIZE PERCENTAGES TO ADD TO $100 * *$;

** (SOME RECORDS ADD TO SOMETHING OTHER THAN 100)**;

IF TOTALI NOT IN $(100,0,$.$) THEN DO;$

IF POFFRD NE. THEN POFFRD $=($ POFFRD/TOTAI 1$) * 100$;

IF PLOCAI NE . THEN PLOCAL = (PLOCAL/TOTALI) $* 100$;

IF PSHORT NE. THEN PSHORT $=($ PSHORT/TOTAII) $* 100 ;$

IF PLONG NE. THEN PLONG $=$ (PLONG/TOTALI) *100;

TOTALI = SUM (POFFRD, PLOCAI, PSHORT, PLONG);

END;

** DISTINGUISH BETWEEN ON-HIGHWAY AND OFF-HIGHWAY **;

IF POFFRD = 100 THEN HIGHWAY = 'OFF';

ELSE IF POFFRD $=0$ OR POFFRD $=$. THEN HIGHWAY = 'ON';

ELSE HIGHWAY = 'MIX';

PROC SUMMARY NWAY DATA = IIGHT;

CLASS HIGHWAY;

VAR ANNMIL; 


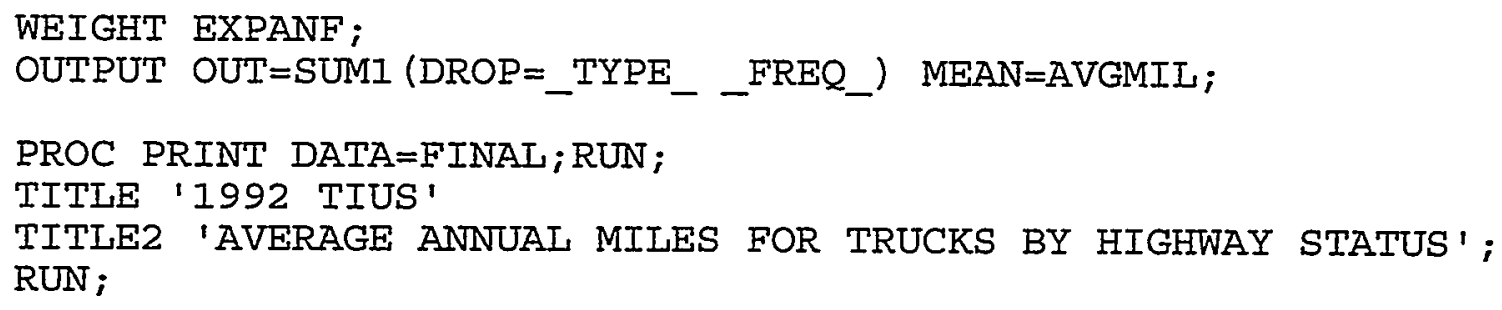




\section{INTERNAL DISTRIBUTION}

1. R. Boundy

2. M. S. Bronzini

3. G. E. Courville

4. T. R. Curlee

5. S.C. Davis

6. P.S. Hu
7. C. I. Moser

8. R. B. Shelton

9. L. F. Truett

10. Central Research.Library

11. Document Reference Section

12. Laboratory Records

13. Laboratory Records-RC

\section{EXTERNAL DISTRIBUTION}

14. L. A. Abron, President, PEER Consultants, P.C., 1460 Gulf Blvd., $11^{\text {th }}$ Floor, Clearwater, Florida 34630

15. S. L. Cutter, Director, Hazards Research Lab, Department of Geography, University of South Carolina, Columbia, South Carolina 29208

16. C. Douwes, Federal Highway Administration, HEP-10, Room 3222, 400 Seventh Street, S.W., Washington, DC, 20590

17. T. E. Drabek, Professor, Department of Sociology, University of Denver, Denver, Colorado 80208-0209

18. R. C. Erickson, Federal Highway Administration, HPM-10, Room 3306, 400 Seventh Street, S.W., Washington, DC, 20590

19. S. G. Hildebrand, Director, Environmental Sciences Division, Oak Ridge National Laboratory, Post Office Box 2008, Oak Ridge, Tennessee 37831-6037

20. P. R. Rittelmann, FAIA, Executive Vice President, Burt Hill Kosar Rittelmann Associates, 400 Morgan Center, Butler, Pennsylvania 16001-5977

21. S. F. Tierney, The Economic Resource Group, Inc., One Mifflin Place, Cambridge, Massachusetts 02138

22. C. M. Walton, Ernest H. Cockrell Centennial Chair in Engineering and Chairman, Department of Civil Engineering, University of Texas at Austin, Austin, Texas 78712-1076

23. OSTI, U.S. Department of Energy, P.O. Box 62, Oak Ridge, Tennessee 37831

24. Office of Assistant Manager for Energy, Research and Development, DOE-ORO, P.O. Box 2001, Oak Ridge, Tennessee 37831

25-50. Center for Transportation Analysis, Building 3156, Room 212, Mail Stop 6073. 